\title{
Big Ding 鼎 and China Power: Divine Authority and Legitimacy
}

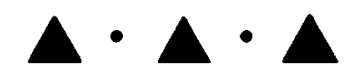

ELIZABETH CHILDS-JOHNSON

By THE EASTERN ZHOU and imperial eras of Chinese history, a legend had grown celebrating the ding 鼎 bronze vessel as the preeminent symbol of state authority and divine power. The mythic theme of "The First Emperor's [Qin Shi Huangdi's] Search for the Zhou Ding" or “The First Qin Emperor's Failure to Discover the Ding" decorate the main gables of more than several Eastern Han funerary shrines, including Xiaotangshan and Wuliang in Shandong province (Wu 1989:138, 348). Pre-Han records in the Zuozhuan: $7^{\text {th }}$ year of Duke Zhao (左传: 昭公七年) as well as the “Gengzhu” chapter in the Mozi (墨子: 耕柱篇) record the significance of this mythic representation. The Mozi passage states:

In ancient times, King Qi of the Xia [Xia Qi Wang] commissioned Feilian to dig minerals in mountains and rivers and to use clay molds, casting the ding at Kunwu. He ordered Wengnanyi to divine with the help of the tortoise from Bairuo, saying: "Let the ding, when completed, have a square body and four legs. Let them be able to boil without kindling, to hide themselves without being lifted, and to move themselves without being carried so that they will be used for sacrifice at Kunwu."Yi interpreted the oracle as saying: "The offering has been accepted.... When the nine ding have been completed, they will be 'transferred' down to three kingdoms. When Xia loses them, people of the Yin will possess them, and when people of the Yin lose them, people of the Zhou will possess them." [italics added]

As maintained in this article, the inspiration for this popular legend of mythic power most likely originated during dynastic Shang times with the first casting in bronze of the monumental, four-legged ding. The name fangding 方鼎 (square ding), traditionally used to refer to four-legged ding bronze vessels, is only known in extant Eastern Zhou received texts. ${ }^{2}$ The name tetrapod or four-legged is used to distinguish this ding type from its other variation and prototype, the tripod or three-legged round-bellied ding. The four-legged version was initially square, but evolved into the primarily rectangular shape by late Shang times.

Elizabeth Childs-Johnson is a scholar who was recently affiliated as Research Professor with the Art Department and Institute of Asian Studies at Old Dominion University. 
The purpose of this article is not to trace the evolution of big ding from Shang through Eastern Zhou and Han times but to clarify the function of the monumental tetrapod as a symbol of power and divine authority for the king during the Shang era c. 1640-1046 B.C.E. Leaving aside disputes about the existence and characteristics of a preceding "Xia dynasty," Shang was the earliest undisputed dynastic state in China. It had an extensive territory and ruled from a series of semipermanent capital cities that functioned as centers of political, military, and socioreligious power. Power in the Shang state was transmitted dynastically, with ruling authority passing in hereditary succession from kings to their brothers or sons (Chen 1956; Shima 1975:78-80; Yang 1976; Yang 1992:1-14). ${ }^{3}$ Shang was the name of the ruling house, as documented by references in late Shang bone inscriptions and corroborative archaeological discoveries. ${ }^{4}$ Later Eastern Zhou and Han literary texts sometimes refer to the Shang as Yin, after Yinxu 殷墟 (meaningYin ruins), the location of the last Shang capital near present-day Anyang.

The Shang period is currently divided archaeologically into early, middle, and late phases. Early Shang is dated to c. 1640-1400 B.C.E. and refers primarily to the Erligang period as represented by site finds at Zhengzhou (Henan 1999, 2003) and related ones such as at Yanshi Shangcheng (Du 2003; Zhang et al. 2005). As clarified by Tang Jigen (1999:393-420), the middle Shang period (1400-1300 B.C.E.) may be identified with newly excavated material from the northern suburbs of Anyang municipality, known by the type-site Huanbei Huayuanzhuang or Huanbei Shangcheng (Shang City North of the Huan River). Late Shang belongs to c. 1300-1046 B.C.E., the time when Yin served as the dynasty's last capital. ${ }^{5}$

\section{BACKGROUND}

There have been virtually no analyses of big ding in particular or their general cultural context using Shang period evidence to demonstrate how they were used, who used them, and what they signified during Shang times. ${ }^{6}$ In the early 1990s, Yang Baocheng and Liu Senmiao brought together various Shang tetrapod ding (fangding) and analyzed them typologically (Yang and Liu 1991:533-545; Yang 2002:160-180), but their conclusions did not extend beyond the observation that the largest ones probably belonged to royalty and those of medium and small size probably belonged to other ranking elite. Much earlier, Hayashi Minao assembled a mammoth typological study of bronze vessels throughout the Bronze Age, including tripod and tetrapod ding and their nomenclature (1964:34-35).

Others have used the five large-scale ding from excavations of the last Shang capital near Anyang as a means of dating and setting straight the chronology of the Shang. For example, Virginia Kane (1976) theorized long ago that one of the large Anyang ding, the Hou $\mathrm{Mu} \mathrm{Wu}$ tetrapod ding, stylistically postdated the two other large tetrapod ding from the royal M1004 burial at Anyang, accounting for a burial that could postdate King Wu Ding in identifying another late Shang king's (Wu Yi's) queen. However, no scholar has looked at the Shang material holistically, utilizing bone inscriptional data together with archaeological and art historical data to put these significant receptacles into perspective regarding Shang cultural interests and belief systems. 


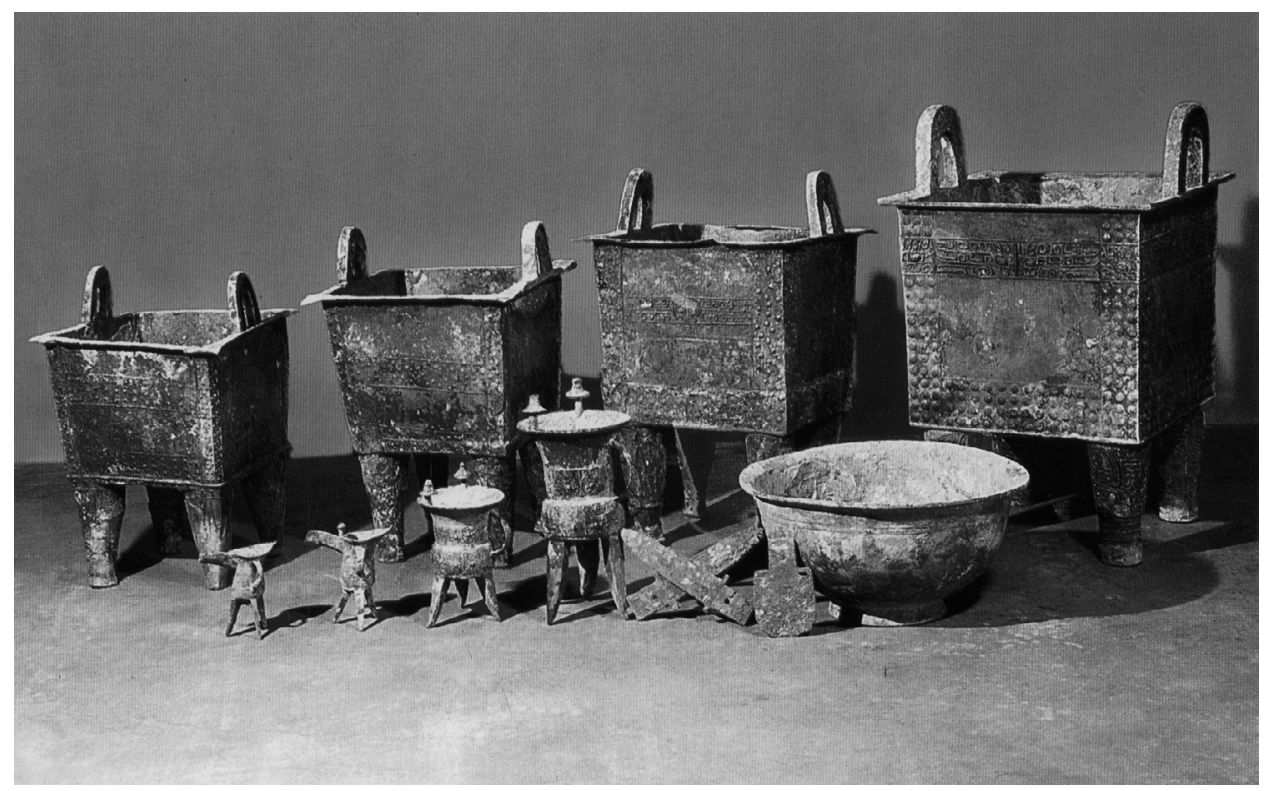

Fig. 1. Bronze vessels aligned by size, from South Shuncheng St., Erligang. Source: Henan 1999: colorpl. 2.

\section{SHANG PERIOD ORACLE BONE EVIDENCE FOR THE DING VESSEL SACRIFICE}

Tetrapod ding were first cast in bronze during the Shang period by Shang or other peoples under Shang jurisdiction or cultural influence. They first appear in excavations at the early Shang type-site of Erligang in Zhengzhou, Henan (Fig. 1). These vessels are big and heavy and vary in weight and wall thickness; they are the largest type of cast "ritual" objects known thus far from the early Bronze Age (c. 1900-1100 B.C.E.). Traditionally, it has been assumed that bronze vessels were always used ritually because by the end of the Shang period they carried brief inscriptions referring to the owner (a clan or individual) or object of the sacrifice- not a living person, but a deceased royal ancestor known by a posthumous title. ${ }^{7}$ Data that have not been used before to document the ritual use of vessels, but are illuminating and well known to oracle bone specialists, come from a series of ongoing zhouji 周祭 ancestor cult rites divined about in Shang bone inscriptions. Repeated throughout the year, the rites were addressed to high ancestors, deceased rulers, and consort queens (Chang 1987; Hsü 1968; Tung 1964). "Rituals" and "rites" discussed here thus refer to the use of ding and other specialized vessel types for sacrifices during these cyclical rites. Although in this article the zhouji will not be comprehensively reviewed, representative inscriptions relating to the use of the ding vessel will be introduced to clarify the primary function of bronze vessels in these ongoing cyclical ancestor cult rites during the Shang era. After reviewing the data, other archaeological and paleographic data will be analyzed to reach the principal conclusion that the monumental tetrapod ding were produced for the exclusive use of Shang kings and Shang princes eligible for succession to the throne. Thus, their function and primary role were as symbols of divine 
Table i. Excavated Tetrapod Ding, Their Sizes and Measurements

\begin{tabular}{|c|c|c|}
\hline CONTEXT/LOCATION AND REFERENCE & $\begin{array}{l}\text { NO. OF } \\
\text { VESSELS }\end{array}$ & METRIC INFORMATION \\
\hline $\begin{array}{l}\text { Zhengzhou Cache, First cache finds: } \\
\text { 1974, South Zhangsai Street, } \\
\text { Zhengzhou (Henan 1999) }\end{array}$ & 2 & $\begin{array}{l}\text { No. 1: height } 100 \mathrm{~cm} \text {, width } 62.5 \mathrm{~cm} \text {, } \\
\text { weight } 86.4 \mathrm{~kg} \\
\text { No. } 2 \text { : height } 87 \mathrm{~cm} \text {, width } 61 \mathrm{~cm} \text {, weight } \\
64.25 \mathrm{~kg}\end{array}$ \\
\hline $\begin{array}{l}\text { Zhengzhou Cache, Second cache finds: } \\
\text { 1982, Moslem Grocery, Xiangyang } \\
\text { (Henan 1999) }\end{array}$ & 2 & $\begin{array}{l}\text { H1:2: height } 81 \mathrm{~cm} \text {, width } 55 \mathrm{~cm} \text {, weight } \\
\quad 75 \mathrm{~kg} \\
\mathrm{H} 1: 8: \text { height } 81 \mathrm{~cm} \text {, width } 55 \mathrm{~cm} \text {, weight } \\
\quad 75 \mathrm{~kg}\end{array}$ \\
\hline $\begin{array}{l}\text { Zhengzhou Cache, Third cache find: } \\
1996 \text { (H1) South Shuncheng Street } \\
\text { (Henan 1999) }\end{array}$ & 4 & $\begin{array}{l}\text { H1:1: height } 83 \mathrm{~cm} \text {, width } 51.5 \mathrm{~cm} \text {, weight } \\
\text { 52.9 kg } \\
\text { H1:2: height } 72.5 \mathrm{~cm} \text {, width } 26.7 \mathrm{~cm} \text {, } \\
\text { weight } 26.7 \mathrm{~kg} \\
\text { H1:3: height } 64 \mathrm{~cm} \text {, width } 42.5 \mathrm{~cm} \text {, weight } \\
\text { 21.4 kg } \\
\text { H1:4: height } 59 \mathrm{~cm} \text {, width } 38 \mathrm{~cm} \text {, weight } \\
\text { 20.3 kg }\end{array}$ \\
\hline Pinglu cache (Wei 1992) & 1 & $\begin{array}{l}\text { Pinglu tetrapod ding: height } 83.6 \mathrm{~cm} \text {, width } \\
50 \mathrm{~cm} \text {, estimated weight } 40 \mathrm{~kg}\end{array}$ \\
\hline Xingan burial (Jiangxi et al. 1997) & 2 & $\begin{array}{l}\text { XG 8: height } 97 \mathrm{~cm} \text {, width } 58 \mathrm{~cm} \text {, weight } \\
49 \mathrm{~kg} \\
\text { XG ?: height } 54 \mathrm{~cm} \text {, width } 37 \mathrm{~cm} \text {, weight } \\
10.1 \mathrm{~kg}\end{array}$ \\
\hline Anyang burials & 5 & $\begin{array}{l}\text { M5:789: Hou Mu Xin ding, height } 80 \mathrm{~cm} \text {, } \\
\text { width } 64 \mathrm{~cm} \text {, weight } 128 \mathrm{~kg} \\
\text { M5:809: Hou Mu Xin ding, height } 80 \mathrm{~cm} \text {, } \\
\text { width } 64 \mathrm{~cm} \text {; weight } 117.5 \mathrm{~kg} \text { (Kaogusuo } \\
\text { 1980: colorpl. } 1 \text { and pl. } 3 \text { ) } \\
\text { M260: Hou Mu Wu ding, height } 133 \mathrm{~cm} \text {, } \\
\text { width } 79 \times 116 \mathrm{~cm} \text {, thickness } 6 \mathrm{~cm} \text {, } \\
\text { weight } 875 \mathrm{~kg} \text { (Guojia Wenwuju } \\
\text { 2001: } 26 \text { ) } \\
\text { M1004: Buffalo ding, height } 73.2 \mathrm{~cm} \text {, width } \\
\text { 45.6 } \times 64.4 \mathrm{~cm} \text {, weight } 110.4 \mathrm{~kg} \\
\text { M1004: Stag ding, height } 60.8 \mathrm{~cm}, \text { width } \\
38.0 \times 51 \mathrm{~cm} \text {, weight } 60.4 \mathrm{~kg}(\mathrm{Li} 1970 \text { : } \\
\text { opposite pls. XXIX and XXV) }\end{array}$ \\
\hline
\end{tabular}

authority and royal power that constituted the foundation of the Shang patriarchal system. This symbolic role was the stimulus for the later myth linking ding and dynastic power.

Ding were used for meat offerings for the same reason that jue beaker tripods were used to offer fermented spirits to dead ancestor spirits (Childs-Johnson 1987). The ding had a special function as the only vessel specifically used to prepare and offer meat sacrifices. Below are listed representative inscriptions documenting the rite of offering the flesh of wild and domesticated animals (as well as prisoners of war) in the ding vessel to dead spirits of the Shang royal house: ${ }^{8}$

1. Heji 1306: On the yichou day Bin divined: If the [King] offers meat cut by the yue axe in the ding bronze vessel to Tang [the 7th Shang king], will we [the king and people] encounter danger? 乙丑卜宾贞唐升岁不我鼎亡来鼓? 
2. Heji 27529: Crack-making on the xinchou day: Should bundled sacrifice be offered to Ancestress Geng? Should it be meat sacrifice in the ding? 辛西卜其束妣 庚, 其鼎?

3. Heji 30765: Crack-making on the bingyin day: Should . . . the [King] make an offering of [hunted] stag in the ding vessel? Should it be that . . obtained on the hunt ... ? 病寅卜又...鼎鹿? 其.... 获 ... ?

4. Heji 32125: Crack-making on the jiayin day: Should [the King] on the coming dingsi day offer 30 oxen prepared according to the $z u$-method in the ding to $\mathrm{Fu}[\mathrm{Fa}-$ ther] Ding? 甲寅贞来丁巳奠鼎于父丁组三十牛?

5. Heji 38243: Crack-making on the yichou day, Quan divined: Should Qiang [tribesmen] be used in the ding offering to Bi Xin during the Ji ceremony y Pa? 乙开 犬贞鼎姜其用比辛舟?

Inscriptions involving cyclical sacrifices to the royal registry of kings and queens were typically yes or no inquiries regarding type or number of sacrifice and whether one or the other sacrifice would bring divine assistance or divinely enacted danger. The ding graph 鼎 acts as a verb of sacrifice as dictated by the graph typically having a subject, an indirect object, and a direct object. The subject is usually the king and sometimes another royal house member, the indirect object a deceased king or queen, and the object a sacrifice. The inscriptions above reveal that the royal dead receiving the ding sacrifice included: Tang, the 7th Shang king (no. 1); Fu (Father) Ding, probably Wu Ding, the 27th Shang king (no. 4); Bi (Ancestress) Xin, the consort and first queen of King Wu Ding (no. 5); and Bi (Ancestress) Geng, the consort of the 26th King Xiao Yi (no. 2). These dead kings and queens received sacrifices of various flesh offerings ranging from Qiang prisoners of war to oxen or hunted stag and meat cut and prepared with the yue axe. The various methods of preparing the sacrifices and cooking them over charcoal or fire are revealed in bone inscriptions in connection with the ding sacrifice and archaeological findings of the remains of burnt animal bones in ding bronzes excavated from burials. ${ }^{9}$ In inscriptions 1 and 4 above, meat may be hacked with the yue axe or meat may be cut on the $z u$ cutting board.

Although ritual sacrifices to royal ancestors utilizing bronzes can only be documented epigraphically from late Shang bone and bronze inscriptions, the likelihood that such sacrifices and rites originated long before the late Shang period is based on the typological continuity of Erlitou bronze vessel shapes into the early, middle, and late Shang periods. Erlitou or pre-Shang (Xia) (c.1900-1600 B.C.E.) bronzes, representing the first casting of any ritual vessel used in sacrifice, include four types: jue, jia, $h e$, and tripod ding. All four types continued to evolve during Shang times. Studies of one of the vessel types, the jue tripod beaker by Du (2007a) and Childs-Johnson (1987), demonstrate this continuity.

\section{HIGH RADIOGENIC LEAD FROM THE SICHUAN/YUNNAN BORDER AND OTHER METAL SOURCES FROM SOUTHERN YANGZI RIVER VALLEY SITES DURING THE EARLY SHANG PERIOD OF ERLIGANG}

In comparison to Shang period bronzes, Erlitou period vessels are relatively small in number and scale. Compared with the explosion in production of bronzes in the immediately succeeding Shang centuries, they seem to represent an experimental phase in bronze casting. ${ }^{10}$ According to Li Liu and Xingcan Chen $(2003: 36-56)$, cop- 
per, tin, and other metal resources in the western vicinity of the Yellow River Plain (Zhongtiao Mountains of south Shanxi) were sufficient for the metallurgical needs of the Erlitou state based near Luoyang. ${ }^{11}$ As production of bronze vessels rapidly expanded in both number and scale during the Shang era, however, metal resources were sought from far more distant mines, as demonstrated in metal ore types found in the newly discovered Shang-era copper and lead-zinc mines in the northeastern finger of Yunnan 云南, just across the Sichuan 四川 border south of Chongqing 重慶 near Yibin (Chen et al. 1980; Jin 1990:287, fig. F1.3; Jin 2000:169-194; 2002, 2003:164; 2008:27-29; Zhu and Chang 2002:278). ${ }^{12}$ Furthermore, bronzes are scattered at sites along the Yangzi River valley and west up the Han River as far as southern Shaanxi. Clearly, Erligang citizens were seeking natural sources for creating bronze far from their capital in central Henan.

Metallurgy specialists have pointed out distinctive differences in lead radioisotope content between Erlitou and Erligang bronze alloys. ${ }^{13}$ High radiogenic lead found at the Sichuan border and mining site near Yibin is an alloy found in bronzes of early Shang date from sites scattered throughout the Yellow and Yangzi River valleys. That this specialized lead type is only found in one place in East Asia, at the Sichuan border site, makes it evident that the early Shang had extensive influence and control far south of their capital in Henan.

The southwestern mines reveal an abundant supply of copper and high radiogenic lead that can be traced metallurgically in bronze vessels that stretch from metropolitan Zhengzhou 鄭州 in Henan south as far as regional Sanxingdui 三星堆 in Sichuan (Jin et al. 1995; Jin et al. 1997:245-252). The deposits are located at several sites in the Yongshan Jinsha 永善金沙 region in northeastern Yunnan, on the southeast bank of the Yangzi River, just southeast of Yibin 宜宾 in Sichuan. The region lies on a road known in later Qin and Tang dynasty accounts as the Wuchi 五尺道 or Shimen 石门 路 Road. Running from Yibin to Gejiu 个旧, it passed “through Qingfu 庆符, Yunlian 筠连, Yanjin 盐津, Daguan 大矢, Zhaotong 昭通, and Qujing 曲靖” (Jin 1991 :287-288, fig. F1.3). By late Neolithic times, cultural exchange between these areas, as well as those farther north in Sichuan and farther south in Yunnan and Southeast Asia, was in full operation (Tong 1983:79). It is clear that by the late Neolithic Longshan and early historic Erlitou periods, cultural exchange in jade and ceramic works of art thrived between northern and southern centers, as represented in south Sichuan and ancient Yuenan (modern Vietnam) (Childs-Johnson 1995, 2010; Du 2007b:188-189). Such exchange profoundly stimulated further exploration of natural resources in south China during the subsequent Erligang period.

Exemplary bronzes containing high-radiogenic lead include not only those found at the metropolitan Erligang site, and to a certain extent the late Shang burial of Fu $\mathrm{Zi}-\mathrm{M} 5$ at Xiaotun, Anyang in the north Yellow River valley-but also southern Yangzi River valley finds located in Anhui 安徽 (Du 2007b:185-187) and Hunan 湖南 ( $\mathrm{Lu}$ and Liu 1993), at Panlongcheng 盤龍城 in Hubei 湖北, Xin'gan 新干 in Jiangxi 江西 (Barnes et al. 1988; Jin et al. 1995, 1997; Peng 1985), and Sanxingdui in Sichuan (Jin 2000:169-174; 2008:27-29; Jin et al. 1995, 1998a, 1998b; Young et al. 2010: 1034-1039). ${ }^{14}$

In addition to the southwestern mines, copper and lead sources were available at other southern Yangzi River valley sites farther east, including Daye 大冶 in Tonglushan 銅綠山, Hubei; Ruichang 瑞昌 in Tongling 銅嶺, Jiangxi; and Tongling 銅陵 in Anhui. ${ }^{15}$ The Tongling and Tonglushan sites were active by the latest 
Erlitou/Xia phase and early Shang period (Jiangxi 1997; Jiangxi et al. 1997; Liu and Chen 2003:116-130; Lu 2006; Lu and Liu 1993:118-121; Peng 2010:25-28; Yang 1992:364-387; Yang 1998:238-245). A ceramic potsherd of Erligang date is known from Tonglushan in Hubei (Huangshi 1999) and a ceramic jia of Erligang date, and a ${ }^{14} \mathrm{C}$ date obtained from a wooden support in the mineshaft are known from Tongling, Ruichang, Jiangxi (Jiangxi and Tongling 1990:159). Other Erlitou and Erligang period mine remains have been identified at several sites in the Yangxin region near Panlongcheng in Hubei (Hubei 1992). Shang date mining techniques can be reconstructed at several of these sites, including Tongling in Ruichang, Jiangxi and Tonglushan in Daye, Hubei (Lu 2006:13-31).

$\mathrm{Lu}$ (2006) examines shaft construction, tunnel support techniques, mining pit structures, evidence for pulley and lifting techniques, techniques related to underground tunneling and accessing water, and the remains of copper digging tools. Lu and many other scholars maintain that archaeological data from the middle and lower Yangzi valley strongly document Shang state expansion to the southeast during the Erligang early Shang period (Hubei 2001, 1:501-504; Liu and Chen 2003:116130). Trade in metal ores evidently flourished in the southern stretch of China along the Yangzi River valley by the early Shang period, extending well beyond the middle Yangzi River valley, reaching west and south as far as Sanxingdui, Sichuan, just north of Chengdu and farther southwest to Yibin and Yangshan along the Yangzi River. This explosion in mining for copper and lead across southern China was evidently due to a large-scale expansion in the demand for metals at the end of the Erlitou period and very beginning of the Shang (Hubei 2001:503-504; Jin 2008:64-71; Lu 2006:2329). ${ }^{16}$ The exploitation of ores, particularly copper and lead at sites throughout southern China during the early Shang period, was directly connected to heightened military dominance. The sudden extension of the sphere of influence of the early Shang kingdom and its widening access to metal resources parallel the first casting of monumental bronze vessels, in particular four-legged square ding bronzes. As argued below, these came to signify the divinity and authority of the Shang whose hegemonic reign extended throughout the kingdom.

\section{THE TRIPOD (THREE-LEGGED) AND TETRAPOD (FOUR-LEGGED) DING IN CULTURAL CONTEXT}

The earliest evidence for what would become a link between monumental ding and royal power derives from humble black and gray three-legged (i.e., tripod) ceramic ding. Ceramic tripod ding were made in substantial numbers in the late Neolithic Longshan 龍山 and Yueshi 岳石 periods and throughout the early historic Erlitou period. Most are small, individually sized vessels averaging 14-28 cm tall with 12-25 $\mathrm{cm}$ in mouth diameter (Fig. 2, left) ${ }^{17}$ During the late Neolithic period the ceramic tripod ding changed from a primarily utilitarian, domestic function to a ritual function, as it began to be used for presenting sacrifices of cooked meat to dead ancestors. ${ }^{18}$ The version in bronze (Fig. 2, right), first created during the Erlitou period, was designed for use in the ceremony of feeding meat to dead royalty, as documented in late Shang bone inscriptions listed above. In inscriptions, the ding graph is used as a verb meaning "to offer meat prepared or cooked in the ding vessel" (Fig. 3).

How do we know the tripod bronze ding and not the ceramic prototype is related to the graph for the ding sacrifice? During the Erlitou and Shang periods, bronze tri- 


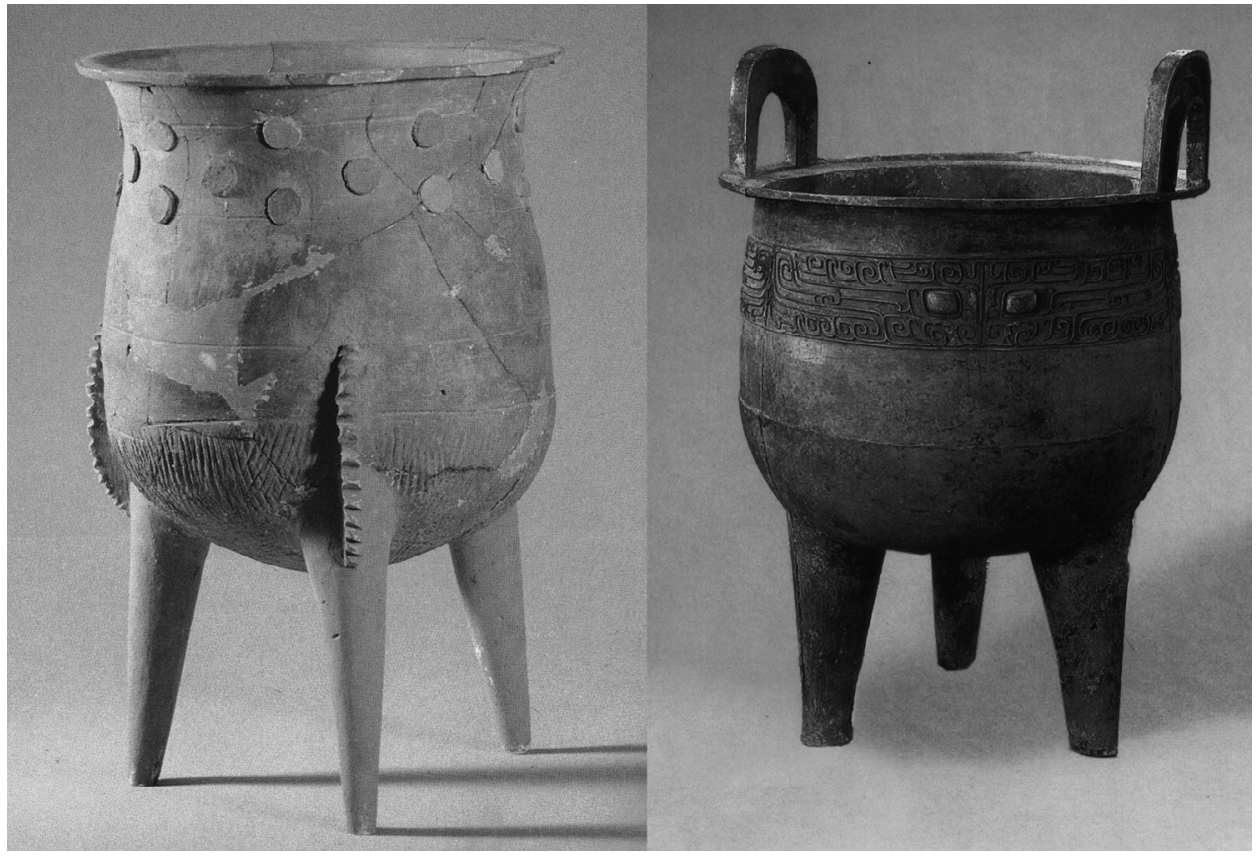

Fig. 2. Ceramic tripod ding (left) from Erlitou and bronze tripod ding (right), from Zhengzhou. Sources: Kaogusuo 1995: colorpl. 16 (left); Henan 1999: colorpl. 12 (right).

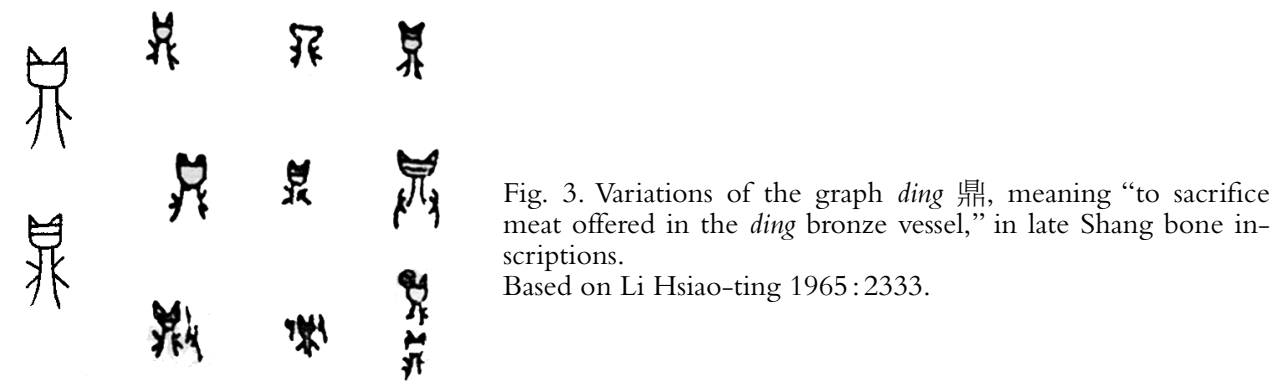

pod ding have two primary variations that differ from their ceramic prototypes-a triangular leg (sometimes in decorative dragon or bird form) and solid in cross section, or tubular and solid (sometimes with a clay core) in cross section. More importantly for our purpose, the major difference between the ceramic and bronze versions of ding vessels is that the former typically do not have prominent handles, whereas the latter typically do (Fig. 2).

The graph that simultaneously signifies the ding 鼎 vessel and meat sacrifice is consistently written pictorially as a vessel with two upright handles attached to a roundshaped bowl on legs. Various early ways of writing the ding graph are shown in Figure 3. Since upright handles do not appear on ding until their adaptation in bronze and the oracle-bone graph pictures a bowl with legs and two vertical handles, it is evident that the Shang bone graph is based on the bronze vessel rather than its utilitarian 
ceramic prototype. This points to the importance of the material bronze and the ding type of vessel in the earliest phase of historical Shang. ${ }^{19}$ It also implies that the bronze tripod ding and its monumental tetrapod version were intimately connected with the rise and legitimization of the royal family.

Several small gray clay cups in square and rectangular shapes with four legs survive in the archaeological assemblage of ceramics at Erlitou during Erlitou periods III-IV (c. 1800-1600 B.C.E.), the time during which large-scale architectural halls were constructed and a major bronze casting center was exploited (Du and $\mathrm{Xu} 2005)$. Three small square cups vary in measurement from 6 to $9.5 \mathrm{~cm}$ tall; another is $25.4 \mathrm{~cm}$ tall. ${ }^{20}$ These cups should not be associated or confused with meat-offering ding of the Shang period, however. Although one of the Erlitou cups has upright handles (83YL IVT18 [3]:1, PIII) (Kaogusuo 1999:229, fig. 144:7), it and the others (Henan 2001, 1:134, fig. 84:8; Kaogusuo 1995:363, no. 242; 1999:229, fig. 144:8) are too small to be related to the massively larger (averaging $54-133 \mathrm{~cm}$ in height) four-legged ding vessel type from the Shang period. Although tetrapod ding vary in size from large to small, the small size of these cups, their limited number, ceramic material, and probable utilitarian function as a drinking vessel indicate that they were not prototypes of the large-scale bronze tetrapod used for meat sacrifices. In addition to the lack of a typological prototype amidst Erlitou remains, there are no extant large-scale vessels in bronze known archaeologically from the Erlitou period. The origin of the tetrapod ding type in bronze thus may be securely dated to the earliest (Erligang) phase of the Shang period, when such vessels first appear on a massive scale in the archaeological record.

\section{THE SACRIFICIAL VESSEL IN CONNECTION WITH THE SHANG KING'S ROLE AS} DIVINE INTERMEDIARY

Not only does the monumental tetrapod ding appear to be a Shang invention, the possession and use of such vessels seem to have been concrete symbols of the divine right to rule granted by Di 帝 (“God," a supreme deity that may be identified with the later Zhou deity Tian 天, "Sky Power"). ${ }^{21}$ The Shang king's divinity is based on his role as diviner or intermediary supreme; he had primary power to identify and communicate with the spirit world of nature, including Di and Di's especially favored humans, the ancestral Shang queens and kings, as related in late Shang bone inscriptions. ${ }^{22}$ The king alone could bin 宾 or "receive spirits" of Di and dead royalty (ChildsJohnson 1995:82-88; 2008:29-37). ${ }^{23}$ The power to bin is intimately tied to the singular power of the king to communicate with Shang Di and deceased spirits of past rulers. The king ruled as a surrogate for Di throughout the four quarters. ${ }^{24} \mathrm{He}$ presided over all rites and administrative affairs, covering divination and sacrifices and all military, political, and economic issues (Chang 1970:263-264; Chen 1956; Shima 1975; Shirakawa 1977; Yang 1992:57-83). There was no distinction between politics and religion in Shang times: the Shang king was the link between that above and that below. ${ }^{25}$ His divine right was affirmed not only by his role as supreme spirit communicator and interpreter but also as chief executioner of all rites addressed to powerful spirits, both natural and human (Chang 1970; Chang 1987; Hsü 1968). As one who ruled from the top of the pyramid, the Shang king was endowed with the most valued commodity of the land-metal resources and the ritual bronze vessel. 
Below is presented data to support the hypothesis that only the Shang king and eligible male heirs could possess such royal power symbols as monumental tetrapod ding and use them in sacrifice to royal ancestor spirits. Four types of data are analyzed to corroborate the king's divine status in association with the monumental tetrapod ding. First, the singularly large size of tetrapod ding and the fact they are associated with royal tombs and related royal contexts is evidence of royal status. A second argument for their royal status is based on evidence that their production was limited to the most elite class of Shang society; this is determined by comparison with bronze vessels excavated from tombs of other ranking elite. Third, inscriptional data provide two more corroborations of royal use of ding, including the presence of the title "Hou $\mathrm{Mu}$ 后母” or “Honorable Queen Mother" inscribed on three of the known extant tetrapod ding and the presence of the specialized binome “yiding 異鼎” in bone and bronze inscriptions, with $y i$ ("divinely endowed") being applied to monumental tetrapod ding.

\section{Tetrapod Ding: The Largest and Heaviest Shang Bronzes Associated with Royal Burials and Caches}

Early Shang: Erligang Period (c. 1640-1400 B.C.E.).- Tetrapod ding from the earliest Shang phase, known as the Erligang period, are of very large size and substantial weight. Significantly, the majority derive from the site of Erligang 二里岡 itself, currently recognized as the first capital of the Shang dynasty (Guojia $2001: 142$ ). ${ }^{26}$ Monumental tetrapod ding are known from three different caches at the Erligang site in Zhengzhou, Henan. ${ }^{27}$ All three cache pits with bronzes seem to have been carefully selected for the purpose of preserving their contents. Excavators have pointed out that preexisting structures such as abandoned wells, storage pits, and refuse pits were adapted for burying ( jiaocang keng 窝藏坑) these treasures (Henan 1999: 1, fig. 1; 96, fig. 1-3). ${ }^{28}$ Each roughly rectangular pit was designed to contain the ritual bronzes, carefully aligned next to each other, with their mouths facing upward and feet downward. The ding are of different sizes, but all are larger than any other vessels found at these sites (see measurements in Table 1). These earliest known tetrapod ding do not appear individually but as pairs or possibly graduated sets. They may have been paired from their inception, reflecting the Shang penchant for dualistic representations of the balance of power. ${ }^{29}$

Two tetrapods were discovered in 1974 at South Zhangsai 張塞南 Street (also known by the site name Duling) (Fig. 4). This pit was a rectangular cavity $6 \mathrm{~m}$ deep designed to contain two large tetrapods (Henan 1999:75). As noted by the excavators, their placement next to each other with mouths facing upward was intentional (Henan 2001 : 513).

Another two, almost identical in size and weight, were discovered in 1982 at the Moslem Grocery, Xiangyang 向陽回族食品厂 (Fig. 5). The Moslem Grocery pit H1 with bronzes was a wide and almost square $(1.7 \times 1.62 \mathrm{~m})$ cavity, dug $4.6 \mathrm{~m}$ deep to accommodate the large pair of tetrapod ding and eleven other bronze vessels (Henan 1999:83, fig. 58). As emphasized by the excavators, the design of pit and placement of ritual bronzes in this cache was purposeful (Henan 1999:93).

The pit at South Shuncheng Street had two periods of usage. The early period level was filled in with earth containing ceramic potsherds datable to an early Erligang Lower Level period. The later period (Erligang Upper Level) use of the pit was dug at 


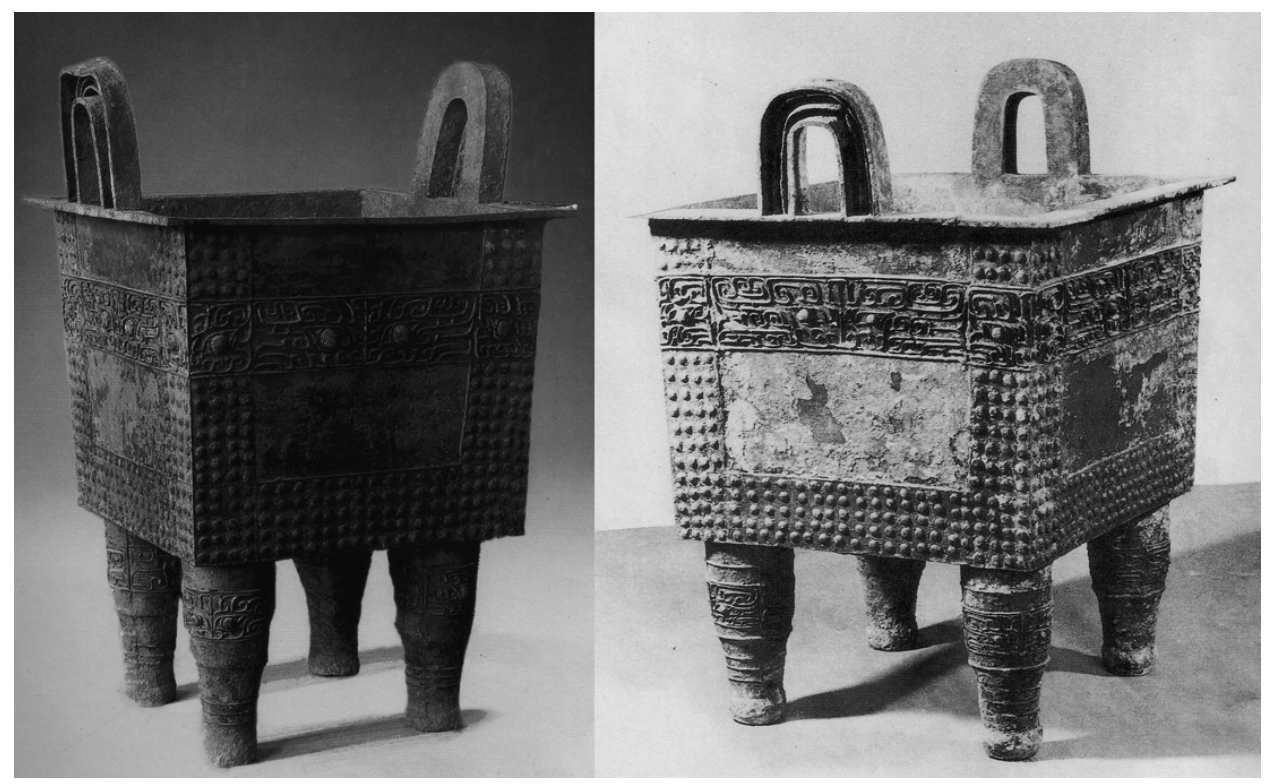

Fig. 4. Two large-scale tetrapod ding from South Zhangsai St. (Duling), No. 1 (left) and No. 2 (right) from Erligang.

Source: Henan 1999: colorpl. 9 (No. 1); 24 (No. 2).

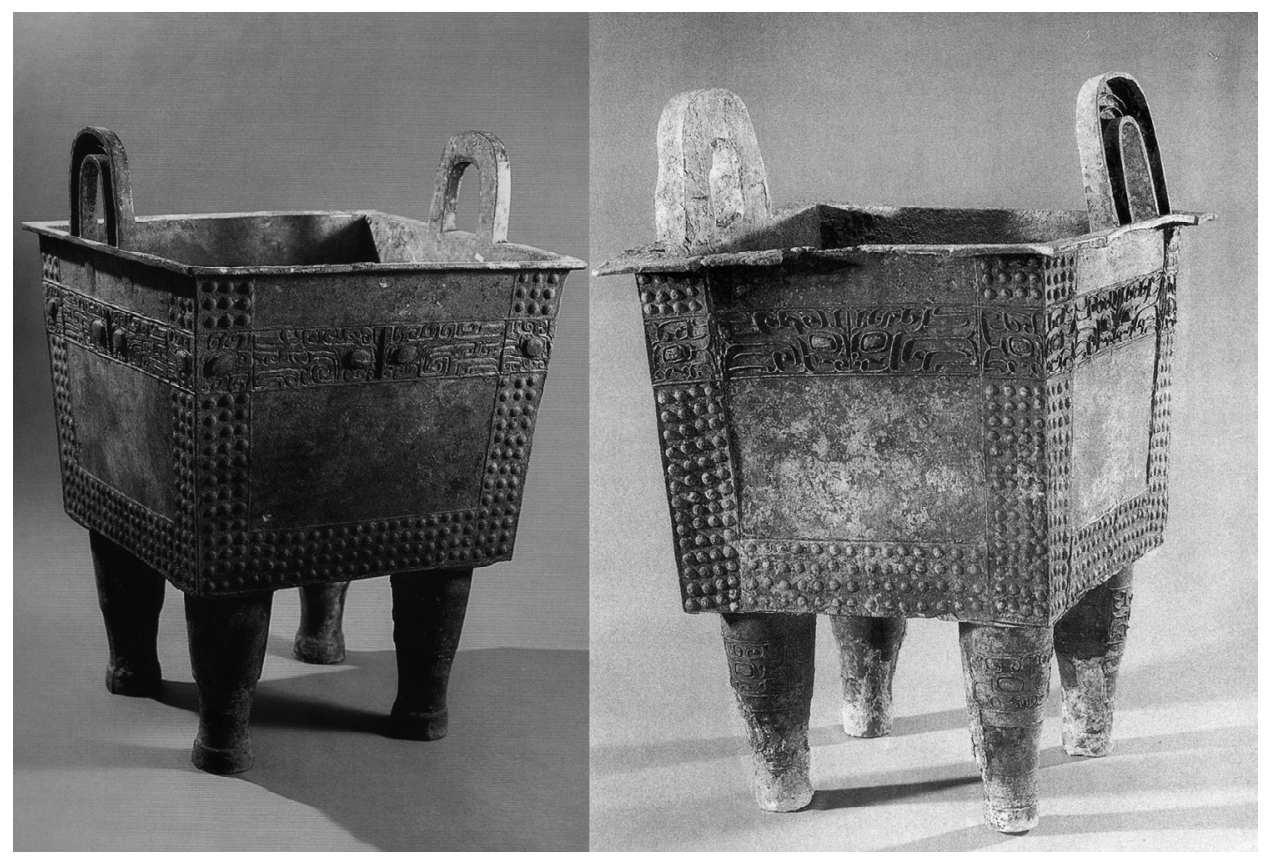

Fig. 5. Two large tetrapod ding from Erligang Moslem Grocery, H1:2 (left) and H1:8 (right). Source: Henan 1999: colorpl. 11:1 (H1:2) and pl. 28 (H1:8). 


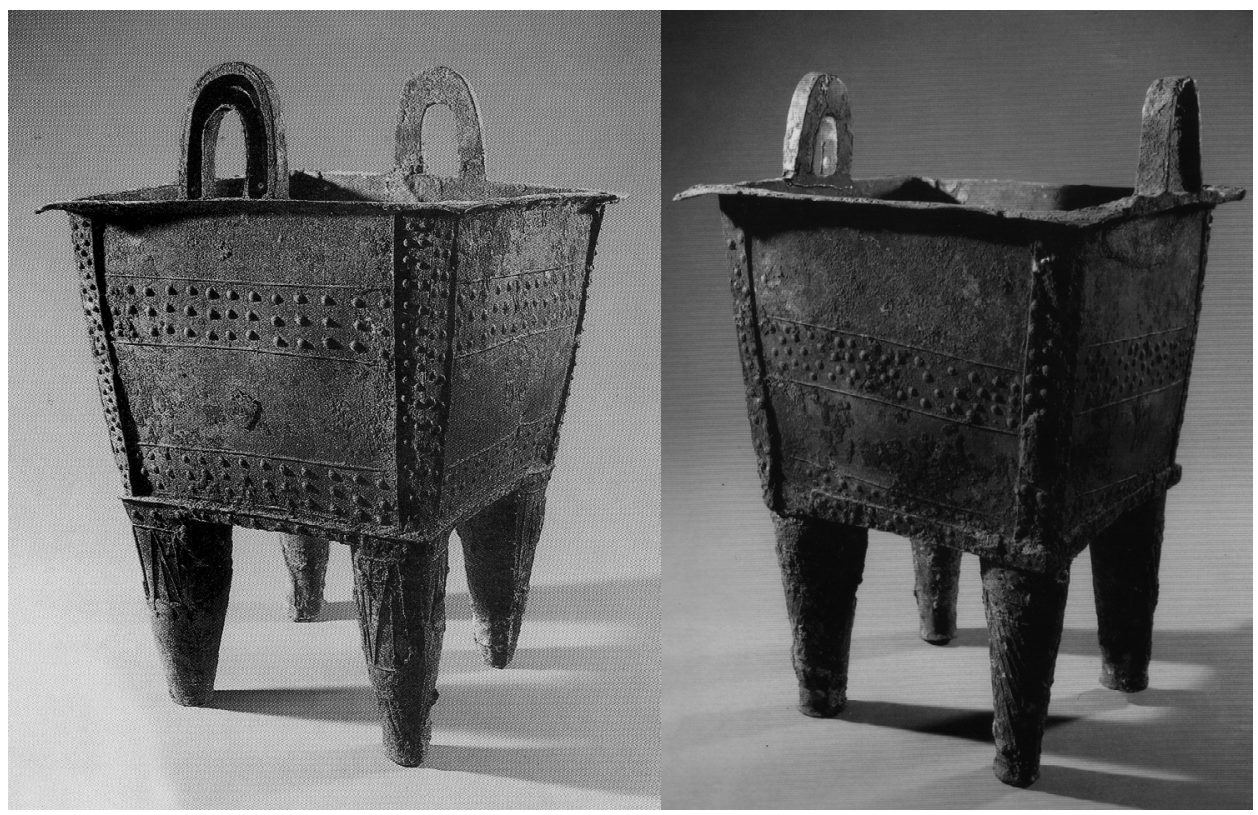

Fig. 6. A pair of large tetrapod ding, from Erligang South Shuncheng St. H1:1 (left) and H1:2 (right). Source: Henan 1999: pl. 3 (H1:1); colorpl. 4 (H1:2).

the base of the pit to store the ritual bronzes (Henan 1999:6-8). At the bottom of this reused pit, in the sixth strata, lay a well-designed wood-constructed lid and base covered with cinnabar to enclose the ritual bronzes (Henan 1999:8, fig. 5).

Four monumental ding different in size and weight were discovered in 1996 at South Shuncheng 南順城 Street (Figs. 6 and 7). It has been suggested that these four are either two different pairs or a size-graduated set of four (Figure 1 shows them ordered by size). The two measuring 64 and $59 \mathrm{~cm}$ (Fig. 6, left and right) are closer in size (6 cm difference) and form to each other than the pair measuring 83 and $72.5 \mathrm{~cm}$ (9.5 cm difference) (Fig. 7, left and right). The first two are almost identical in form and make in that they are similarly cast, are light in weight (between 21.4 and $20 \mathrm{~kg}$ ), have extremely thin walls and lips, are nearly square in shape, vary from 42.5 to $38 \mathrm{~cm}$ tall, and have similar decorations of framing bands with raised nodules, awkwardly aligned vertically along four corners and horizontally in bands on four sides (Fig. 6). That these two were experimental is suggested by their lightweight thin walls and imbalanced décor; they may therefore be identified as the earliest examples of monumental tetrapod ding cast during the Erligang period.

Shang ritual bronze vessels were individually cast in separate molds (never the same mold); they typically were never exactly the same in size or in weight (Gettens 1969:119; Karlbeck 1935). Nevertheless, they often appear in pairs. Monumental tetrapod ding that have been excavated intact from tombs (e.g., M5 and M1004 in Anyang) appear together, suggesting they may have been designed as pairs despite differences in size and weight. Similarly, the two larger ding from South Shuncheng Street are more formally refined than the smaller versions from the same site, and in style and form create a pair. The larger two share the decorative format of a body band 


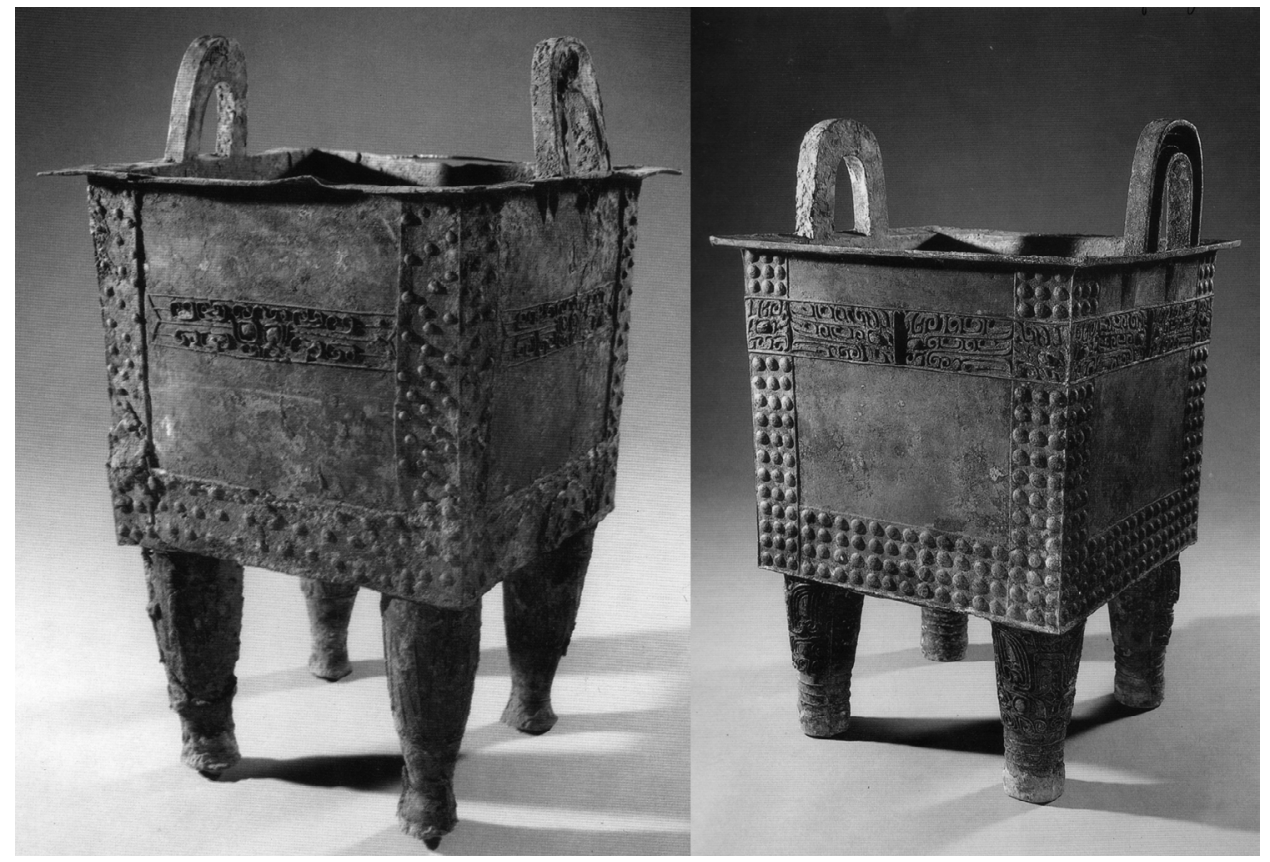

Fig. 7. Second pair of large tetrapod ding, from Erligang South Shuncheng St. H1:3 (left) and H1:4 (right).

Source: Henan 1999: colorpl. 5 (H1:3); pl. 6:1 (H1:4).

with a centralized animal mask motif framed by vertical and horizontal bands of raised nodules (Fig. 7).

All the tetrapod ding found in cache pits outside the inner city wall of Erligang were associated with the occupation of this capital center. That they were found in caches underscores their treasured value and supports the theory that they belonged to highranking members of early Shang society, probably rulers (Henan 2001 :520). Another corroboration of the high regard for the bronzes in these three Erligang pits is the evidence of sacrifices having been made nearby at the time these cache burials were dug and completed (Henan 1999:102). For example, after the South Shuncheng Street cache was constructed with a wooden lid and base, it was covered with a layer of ground cinnabar (mercuric sulphide), a symbolic attribute of Shang ritual elsewhere at the time of burial. ${ }^{30}$ Directly adjacent to the Moslem Grocery cache were two pits (H2 and H4) with animal bones and ceramics suggesting sacrifices offered and buried at the same time the large-scale bronzes were buried (Henan 1999:83-86, fig. 58; 2001:518-519, fig. 345).

Since the caches date late in Erligang Period III, the bronzes cannot postdate this period. Pinpointing whether the bronzes belong to Erligang Period I, II, or III is difficult due to the lack of extant royal bronzes excavated from strata or burials elsewhere at the site. ${ }^{31}$ These bronzes were not inscribed, however, this is typical of early Shang bronzes. Bronzes do not begin to carry inscriptions until the middle and late Shang periods.

Height and corresponding weight measurements are based on a comparison of published and excavated tetrapod ding. Based on known examples, tetrapod ding 


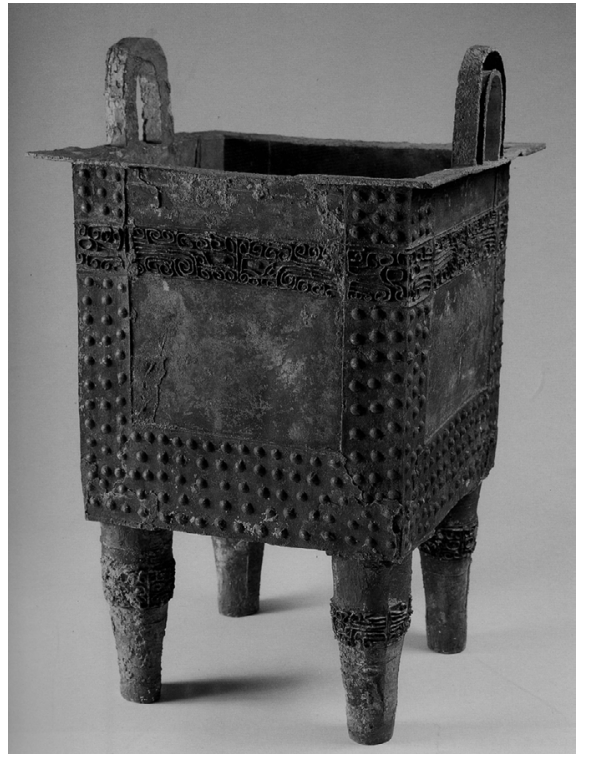

Fig. 8. One large-scale tetrapod ding from Pinglu, Shanxi.

Source: Zhongguo 1997 vol. 1: colorpl. 37.

bronzes fall into three different categories according to size (and weight and wall thickness when published): monumental, medium, and small. Monumental tetrapod ding range from 54 to $133 \mathrm{~cm}$ tall (Table 1); medium-sized ding range from 21 to 43 $\mathrm{cm}$ tall; ${ }^{32}$ and small-sized tetrapod ding range from 12 to less than $21 \mathrm{~cm}$ tall (Table 3). ${ }^{33}$ Compared with the many examples of other bronze vessel types (i.e., tripod ding, $j u e, g u, j i a$ 單 he, gui 筬, zun, $l i$ 鬲, you) from the early Shang period, only a limited number of monumental tetrapod ding have been excavated. This is due to their association with the highest ranks of Shang society.

Another Erligang period monumental tetrapod ding was unearthed in 1990 from early Shang remains at Qianzhuang, Pinglu municipality, Shanxi (Table 1 and Fig. 8). Unfortunately this site has not been formally excavated. Site strata measuring $0.5-1.2$ $\mathrm{m}$ thick occupied a large-scale raised mound approximately 10,000 sq $\mathrm{m}$ (Wei 1992:18-19). Collected ceramic potsherds include zun, li, and gui vessel types, all of which are comparable to early Shang types represented at metropolitan Erligang. Ceramic kiln remains were also identified. Ritual bronze types recovered comprise one monumental tetrapod ding, two large tripod ding, one lei, and two jue. Although the tetrapod ding was found alone rather than in a pair or set, its original context as coming from either a burial or cache is unclear because the finds were collected rather than formally excavated. Nonetheless, in size the tetrapod fits the monumental category. ${ }^{34}$

In 1991 six tetrapod ding of large, medium, and small size were recovered from a burial at Dayangzhou in Xin'gan, Jiangxi, a site located as far as $600 \mathrm{~km}$ east and south of Zhengzhou. ${ }^{35}$ Although Xin'gan was considerably farther away from the early Shang capital at Zhengzhou, like Qianzhuang both were settlements of early Shang metropolitan peoples. ${ }^{36}$ The largest $(97 \mathrm{~cm})$ tetrapod ding and another measuring 54 $\mathrm{cm}$ tall from Xin'gan fall within the monumental category (Fig. 9 left and right). Although their regional site location has no apparent connection to royalty, the size, weight, and style of the ding indicate they were owned by royalty. 

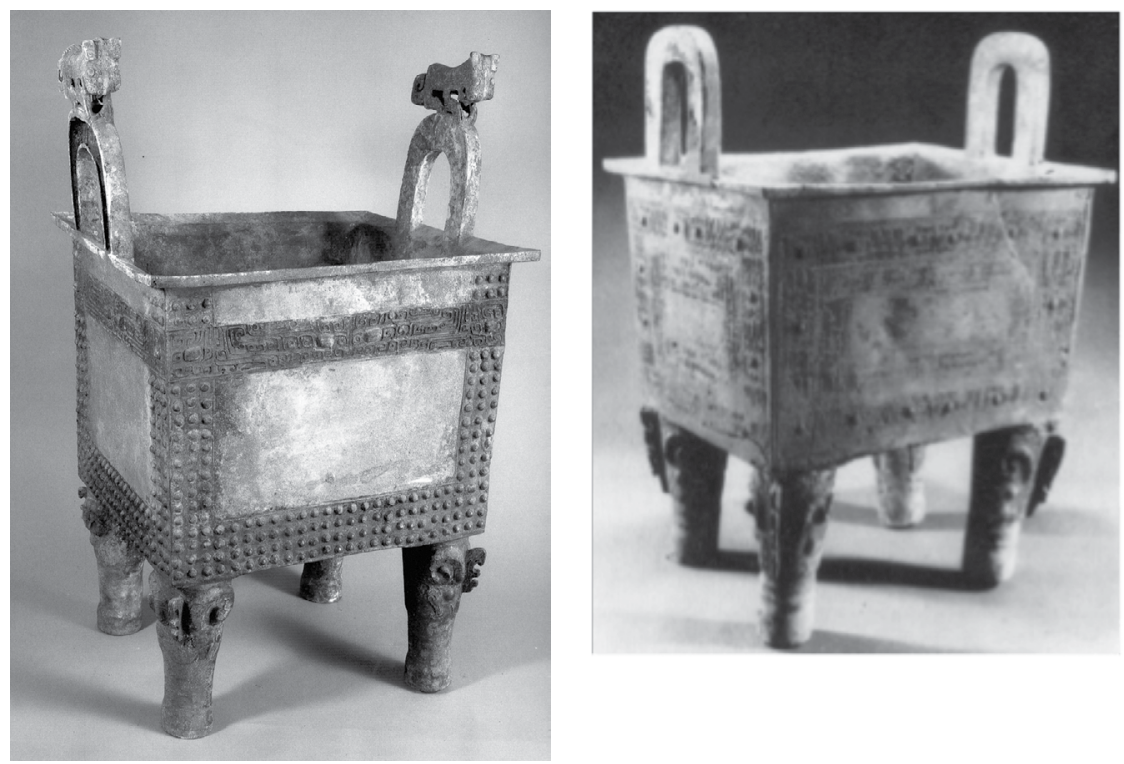

Fig. 9. Two large tetrapod ding, from Xingan, Jiangxi, Nos. 8 and 9. Source: Jiangxi et al. 1997: colorpl. 8 and fig 11.1.

There has been debate about whether the Xin'gan find is a burial or a cache (Peng 2010:57-58; Peng 1997:137). Excavators have argued that the 1,374 bronze and other artifacts found with the monumental tetrapod were part of an elite burial (Jiangxi et al. 1997:1-7). Although the site sits in a flooded area that has left little evidence of any burial apparatus such as a wooden coffin or chamber and there is no evidence of a corpse, the surviving remains are laid out in a way typical of a burial. Two rectangular pits were identified as an outer coffin chamber measuring $8.22 \mathrm{~m}$ long $\times 3.60 \mathrm{~m}$ wide and an inner coffin measuring $2.34 \mathrm{~m}$ long $\times 0.85 \mathrm{~m}$ wide. $\mathrm{Er}$ cengtai 二层台 (side platforms) of packed rammed earth were identified on western and eastern ends; they lay above the coffin area as would shelves holding sacrificial utensils. The ledges and rectangular orientation of pit and coffin typify burial practices from as early as the Longshan Neolithic in Shandong and Henan (Chang 1986:250, fig. 206; Underhill 2002:100, 150-151) and elite burials throughout the Erlitou and Shang periods. ${ }^{37}$ The many bronzes and related artifacts were contained either within the context of the rectangular coffin or within the coffin chamber; weapons and personal items were located within the coffin pit near what would have been the corpse of the deceased. Bronze vessels and additional weapons were placed on top of the coffin, chamber roof, and ercengtai platforms at eastern and western ends. Remains of teeth belonging to one female and two youths found in the vicinity of the coffin pit identify human sacrifice at the time of burial (Jiangxi and Ruichang 1997:1-9). Sacrifice, coffin and chamber forms, and the intentional arrangement of burial bronzes match burial practices of the Shang period. Although the site is an exotic mix of local and metropolitan styles, there is reason to associate this find with a royal Shang burial.

The hypothesis that large-scale tetrapod ding belonged to Shang kings or their heirs may be argued initially from size and weight alone. They are the most monumental art form of the period, so could only have been cast and used by members of the ruling 


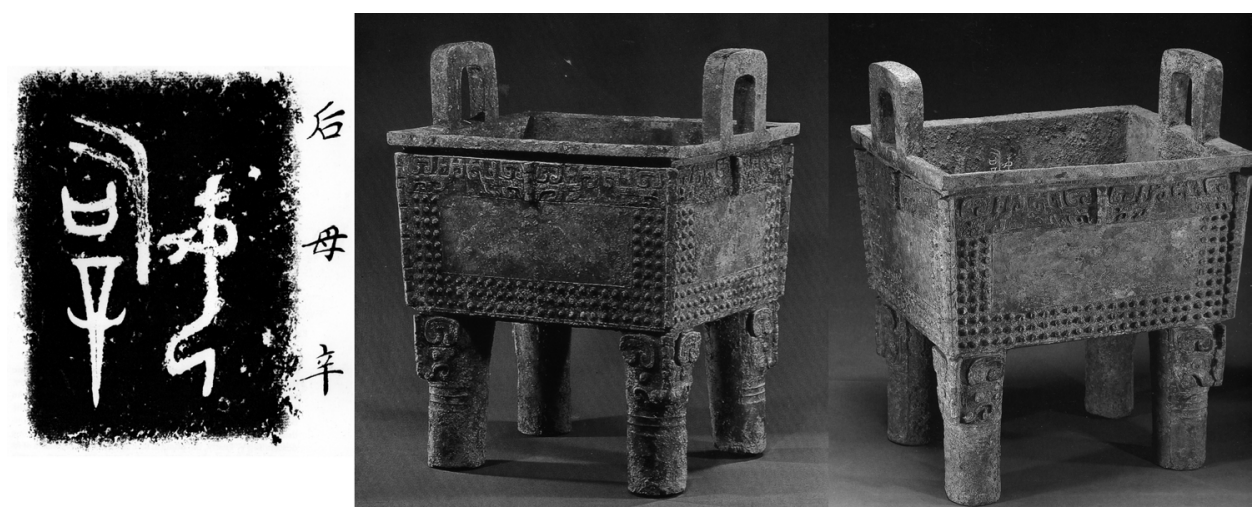

Fig. 10. The identical inscription (left), Hou Mu Xin, appears on two large tetrapod ding from Xiaotun, Anyang, M5:809 (center) and M5:789 (right).

Sources: Inscription (left) Kaogusuo 1980: fig. 25:2, p. 37; photo (center) Kaogusuo 1980: colorpl. 1; photo (right) Zhongguo 1997 vol. 2: colorpl. 39.

elite who controlled significant power and material resources. ${ }^{38}$ Early Shang kings were fixated on access to valuable bronze ores that resulted in military expansion and economic hegemony far south of their northern metropolitan center.

Late Shang (c. 1300-1046 B.C.E.).-Although no tetrapod ding of middle Shang date (c.1400-1300 B.C.E.) has yet been discovered, monumental tetrapod pairs or graduated sets were probably produced during that period because they continued to be produced in late Shang times. ${ }^{39}$ Pairs of monumental tetrapod ding of late Shang date are represented by examples from what are identified as three royal burials at the late Shang capital of Yin 殷, in present-day Anyang 安陽 in northern Henan province. One pair comes from Queen Fu Zi’s 婦子 tomb (M5) at Xiaotun 小屯 (Fig. 10). ${ }^{40}$ Another pair is from the royal burial M1004 at Xibeigang 西北崗, identified with one of King Wu Ding's sons (Fig. 11). Another ding that might originally have been part of a pair comes from M260, theorized to be the tomb of Queen Mother Wu (Hou $\mathrm{Mu} \mathrm{Wu}$ 后母戊), east of Xibeigang, Anyang near Wuguancun 武官村 (Fig. 12).

The huge cruciform-shaped tomb M1004 has long been known to be a royal burial belonging to a late Shang king. Although isolated due to looting, the two monumental tetrapod ding found within, at the very bottom of the tomb, may also be identified with royalty. The latter two tetrapods from M1004 are well known because of the large images of animal heads of wild Sika deer and wild buffalo set in relief on their outer walls and complete figures of stag and buffalo in profile engraved in the center interior of each (Fig. 11). This pair of ding most likely belonged to Fu Ji 父已, the first heir of King Wu Ding 武丁 and Queen $\mathrm{Fu} \mathrm{Zi}$, who died before ascending the throne (Cao 2007:113-122; Childs-Johnson 2003:626; Huang 1989:31). As heirapparent, $\mathrm{Zu} \mathrm{Ji}$ had the right to be buried in a royal tomb (i.e., Xibeigang M1004) with a pair of royal-sized tetrapod ding vessels.

The stag ding from M1004 is the smallest late Shang example at $60.8 \mathrm{~cm}$ tall, while the tetrapod ding from M260 is the tallest and heaviest of all Shang examples. The latter tetrapod was discovered in 1939 during the Sino-Japanese War within burial no. 260 (M260), a large tomb with a long, narrow southern ramp, located south of royal burial M1400 and the Wuguancun Large Burial in the eastern section of the royal cemetery at Xibeigang (Guojia 2001:26; Kaogusuo Anyang Gongzuodui 1987, 

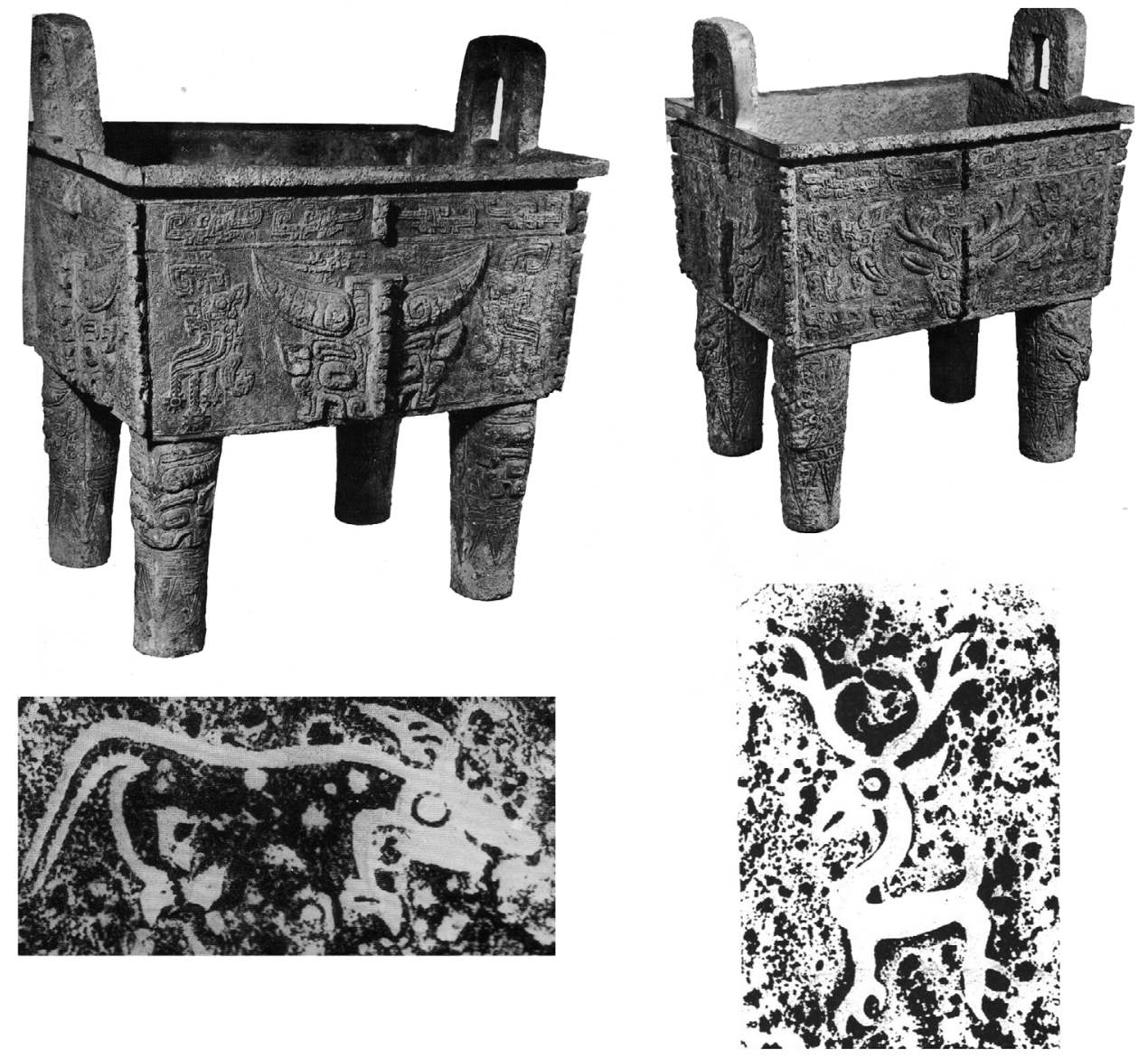

Fig. 11. Two large-scale tetrapod ding inscribed with buffalo (upper left) and Sika deer (upper right) and their respective graphs (enlarged below the vessels), from the "Fu Ji" burial M1004, Xibeigang, Anyang. Source: Li 1970: opposite pls. XXIX and XXV.

1:99-117). The tomb was emptied of all other burial goods, so whether another tetrapod ding or other sacrificial bronzes were originally supplied cannot be verified. With a height of $133 \mathrm{~cm}$ and weight of $875 \mathrm{~kg}$ this massive tetrapod ding is the largest and heaviest of all extant examples. As discussed next, size, weight, and shape made a difference in the sumptuary laws of the Shang elite, particularly in relation to hierarchical position within the elite stratum of society.

Monumental Tetrapod Ding Belonged to the Ruling Class; Tripod Round Ding Belonged to All Elites

In addition to the large size and weight of the tetrapod ding and their context in association with royal burials and royal caches, other characteristics support the contention that they were owned by the rulers of Shang society. The late Shang elite was highly stratified; regulations governed which subgroups could employ which type, number, and size of bronze vessels. Monumental tetrapod ding seemed to have been 


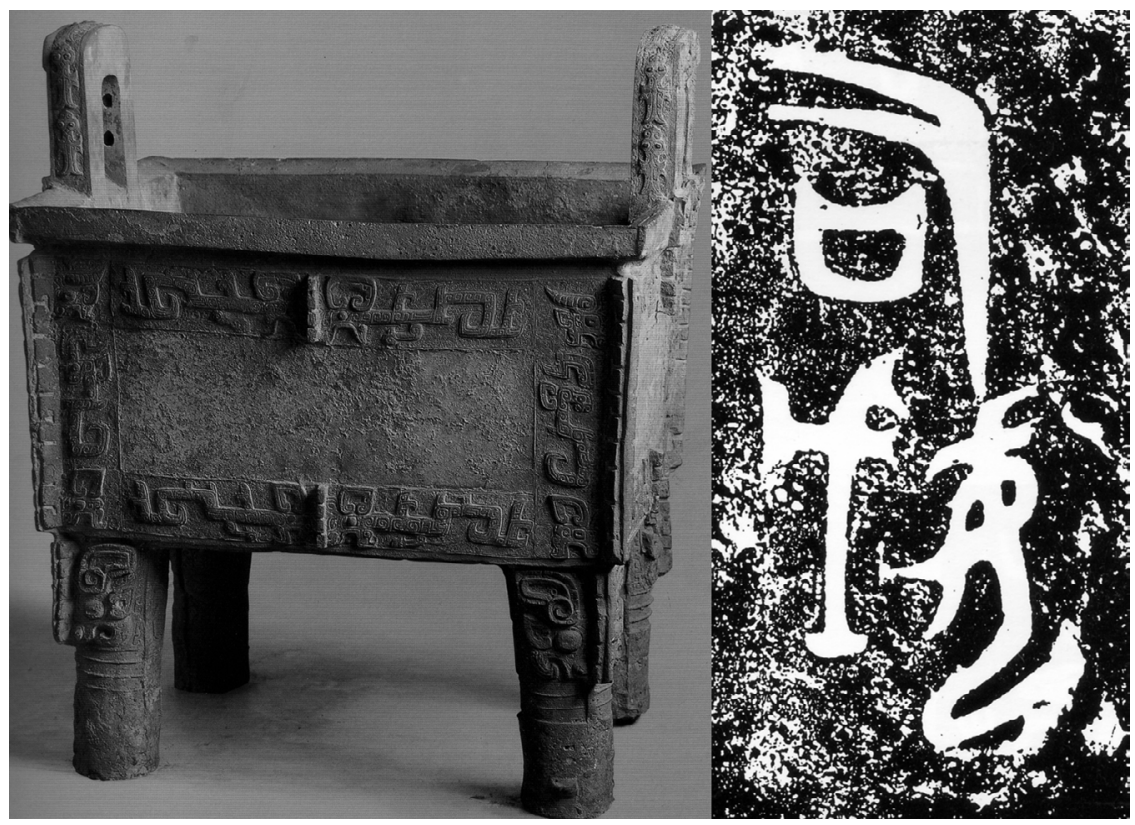

Fig. 12. A large-scale tetrapod ding (left) and its inscription Hou Mu Wu (right), from burial M260, Wuguancun, Anyang.

Source: Zhongguo 1997 vol. 2: pl. 46 (left) and fig. p. 24 (right).

restricted to royalty, while all elite classes could own tripod ding. This is also true for early and middle Shang elite, as demonstrated through size and number and types of bronzes found in burials. Most elite burials of members of the top three ranks of society (i.e., Jia, Yi, Bing) were filled with pairs or sets of ritual bronze vessels similar in shape and décor.

Based on Zou Heng's (1980) pioneering work identifying status and rank of Shang society through size and shape of burials, it is possible to assign rank in Shang society from ritual bronze vessel assemblages. Song and Liu (2006:253-261) and others stratify elite Shang society into "royal family members," "aristocrats," "military," and "retainers" (Song 2005; Yang 1980, 1992). These ranks are reflected in types of burials classified from top to bottom using formal Chinese day names per Zou Heng (1980): Jia A and B, Yi, Bing, Ding, Wu, Ji, and Geng (Table 2). We assign all Jia A type burials to kings and Jia B type burials to queens. ${ }^{41}$

The late Shang M5 burial was excavated intact and has been clearly identified as the tomb of Fu Zi (a.k.a. Hou Mu Xin), the first queen of King Wu Ding (Kaogusuo 1980). It is the richest burial known thus far from the entire Shang period. The vessels from her burial can be compared with those excavated from other burials to corroborate vessel type distribution. It should be noted, however, that the form and size of the M5 burial is atypical of royal types of the late Shang period (Childs-Johnson 2003:222; 2007). The size is small in scale in comparison to the cruciform-shaped burial of M1004 or the large rectangular pit burial with a single southern ramp represented by M260. Queen Fu Zi (Hou Mu Xin) and her son Fu Ji died prematurely during Wu Ding's reign. This is presumably the reason why, despite her fame as a heroine, mother, and warrior, $\mathrm{Fu} \mathrm{Zi}$ was not buried in a large tomb or within the royal cemetery at 
Table 2. Elite Shang Burial Types

\begin{tabular}{|c|c|}
\hline BURIAL TYPES & DESCRIPTION \\
\hline Jia A type & $\begin{array}{l}\text { Burials approx. } 250-350 \mathrm{sq} \mathrm{m}(1 \times \mathrm{w}) \text { in } \gamma a \text { 亞-shape; over } 200 \text { bronzes including a } \\
\text { large-scale tetrapod ding pair }\end{array}$ \\
\hline Jia B type & $\begin{array}{l}\text { Burials approx. } 150-250 \mathrm{sq} \mathrm{m} \text { in a zhong 中-shape; }{ }^{\star} \text { over } 200 \text { bronzes including a } \\
\text { tetrapod ding pair and } 10 \text { jue and } g u \text { to a set }\end{array}$ \\
\hline Yi type & Burials approx. $40-80$ sq $\mathrm{m}$ in a zhong-shape; approx. 100 bronzes (?) \\
\hline Bing type & $\begin{array}{l}\text { Burials approx. } 10-30 \mathrm{sq} \mathrm{m} \text { in a } z \text { hong-shape/ rectangular pit with southern ramp; } \\
20-30 \text { bronzes with } 5 \text { jue/jiao and } 5 \mathrm{gu} \text { to a set }\end{array}$ \\
\hline Ding type & $\begin{array}{l}\text { Burials approx. } 5-10 \text { sq } \mathrm{m} \text { in a rectangular pit shape; approx. } 10 \text { bronzes with } 2-3 \text { jue/ } \\
\text { jiao and } 2-3 \mathrm{gu} \text { to a set }\end{array}$ \\
\hline Wu type & $\begin{array}{l}\text { Burials approx. } 2-7 \mathrm{sq} \mathrm{m} \text { in a rectangular pit shape; under } 10 \text { bronzes including a pair } \\
\text { of } 1 \mathrm{gu} \text { and } 1 \text { jue }\end{array}$ \\
\hline Ji type & $\begin{array}{l}\text { Burials approx. } 1-4 \text { sq } \mathrm{m} \text { in a rectangular pit shape; no ritual bronzes, usually } 1 \text { bronze } \\
\text { weapon }\end{array}$ \\
\hline Geng type & Rectangular pit burials with flexed corpses and no burial goods \\
\hline
\end{tabular}

$\star$ With the exception of the M5 burial discussed in the text.

Xibeigang (Childs-Johnson 2007:23). The large number of bronzes (210) and other gifts buried with her and the various inscriptions on these bronzes nevertheless underscore her rank as queen. ${ }^{42}$ Thus, despite its small size, both the M5 burial of Fu $\mathrm{Zi}$ and the M260 burial of Wu Ding's third wife, Hou Mu Wu, are tentatively classified here as Jia B queen burials until more comparative excavated and measurable data become available.

Yi type burials belong primarily to other royal family and high-ranking military leaders, such as Chang $\mathrm{Zi} \mathrm{Kou}$. Bing type burials belong primarily to aristocrats and lesser ranking military members such as Ya Chi and Ya Chang, and Ding to retainers and related elite. Wu type burials belong to various professional classes. Ji type burials most likely identify soldiers, and Geng type burials, laborers. Representative early and middle Shang tombs include Lijiazui M1 (Bing type) and Lijiazui Nan M1 (Ding type) at Panlongcheng, Hubei of early Shang date and M333 (Ding type) at Xiaotun, Anyang, Henan, Baijiazhuang West M3 (Ding type) at Zhengzhou, Henan, and Pingguxian, Hebei of middle Shang date. Representative late Shang tombs include M5 (Jia B type) of late Shang period II at Xiaotun; Ya Chang M54 (Bing type) at Huayuanzhang, north of the Huan River at Anyang, Henan, of late Shang period II; Ya Chi M160 (Bing type) at Guojiazhuang of late Shang period III; and Chang Zi Kou M1 (Yi type) at Luyi, Henan of late Shang period IV.

Based on research correlating these ranks according to burial type, size, and shape, and according to number and type of ritual bronze vessels, it is evident that major differences existed during the Shang between who could or could not own monumental tetrapod ding, medium- and small-sized tetrapod ding, and tripod ding (Table 3). Monumental tetrapod bronze ding were made and employed in limited numbers compared with the tripod version, common in burials throughout the early, middle, and late Shang (Table 3). Although tetrapod ding also exist in medium and small sizes and tripod ding exist in large sizes (replacing monumental tetrapod ding during the tenth/ninth centuries B.C.E. of the Western Zhou era), scale is significantly different between large tripod ding and large tetrapod ding. Monumental tetrapod ding are always larger than their tripod counterparts during the Shang era. Smaller tetrapod ding 


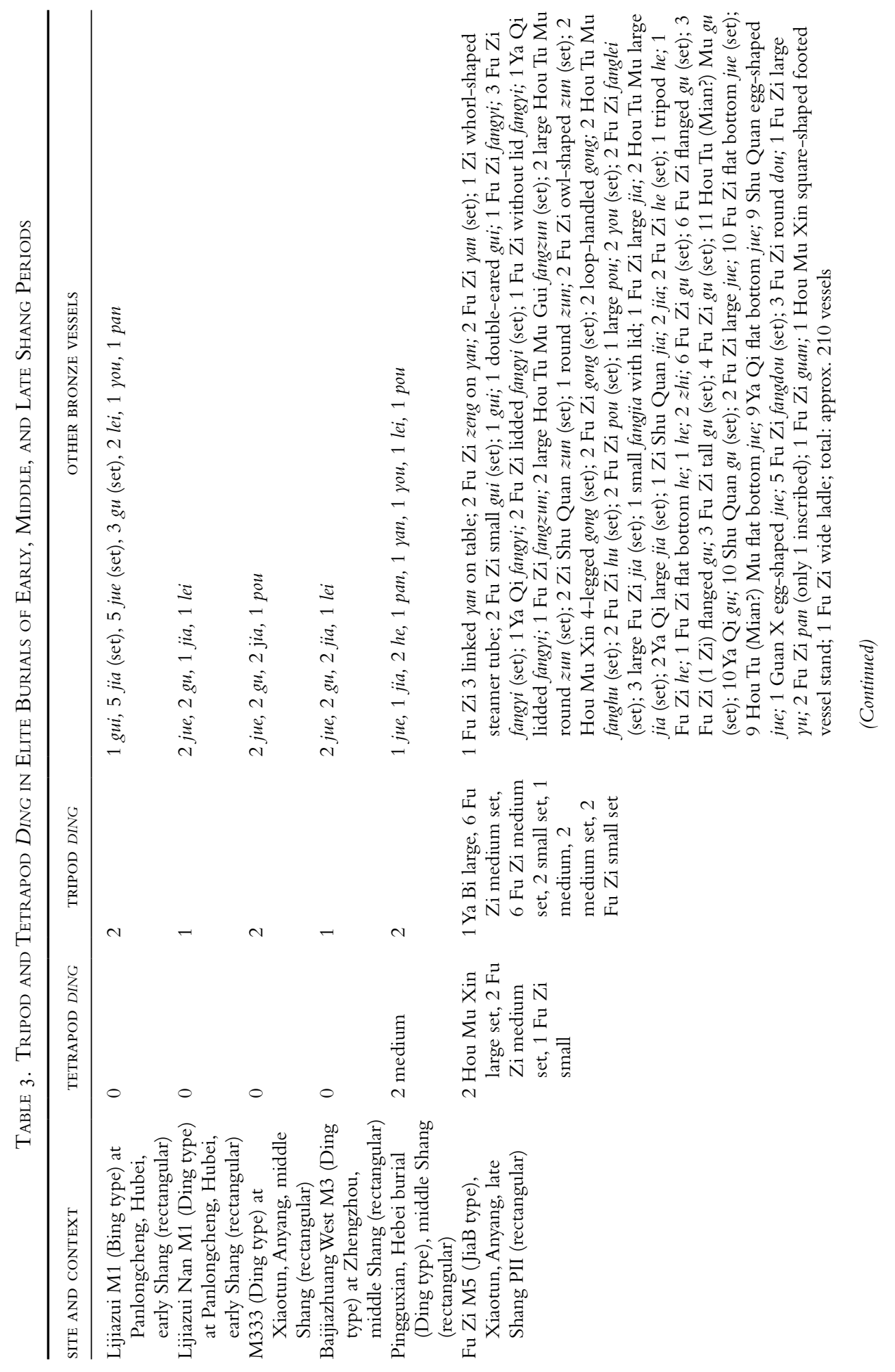




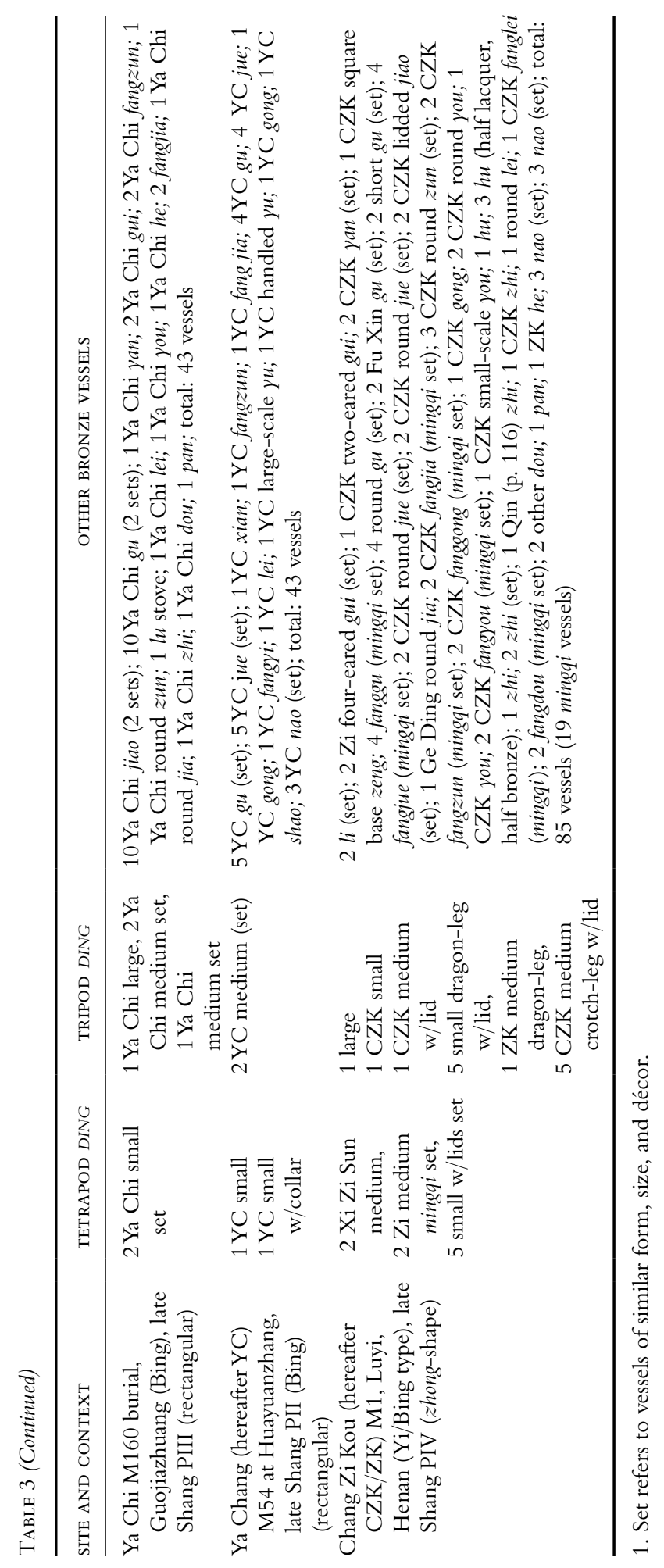


are never found in burials below the rank of Ding, although tripod ding are ubiquitous at all levels of elite burials: Jia, Yi, Bing, Ding, Wu, and Ji. Bronze vessels are consistently absent in Geng laborer and slave burials.

Large-scale tetrapod ding are limited to Jia A and B burials belonging to kings and queens, and thus clearly rank as royal status symbols. This artifactual data needs to be emphasized. Medium- and small-sized tetrapod ding are also distinguished according to rank, because they appear in Jia through Ding class burials but are limited in number. Tripod ding, on the other hand, are numerous and found in all elite burial types ranging from Jia through Wu and Ji ranks (Table 3). Thus, the tripod ding was a staple of Shang society whereas the tetrapod ding was a specialized type owned according to clear-cut rules of rank.

Fu Zi's burial bronzes may be used to analyze several enigmatic aspects of bronze use by rank. Her burial contained three types of ritual vessels: 1) those used by her, indicated by inscriptions with her living name $(\mathrm{Fu} \mathrm{Zi})$ or with her mother's posthumous name, Hou 奐 Mu Gui; 2) those dedicated and given to her by other royals, inscribed with her posthumous ritual name (Hou Mu Xin or Mu Xin); and 3) those given to her by nobility, inscribed with their various names of ownership. ${ }^{43}$ As is evident from her burial goods, during her lifetime she owned 18 medium-sized and small-sized round tripod ding, all inscribed with her living name, $\mathrm{Fu} \mathrm{Zi} \mathrm{(Kaogusuo}$ 1980:38, 41-44; Fig. 13 and Table 3). She also owned and used two medium-sized tetrapod ding with dragon-shaped legs (Nos. 812-813) and one small-sized (no. 834), by evidence of inscriptions with her living name, Fu Zi (Fig. 13) (Kaogusuo $1980: 34-35,38)$.

All 28 medium- and small-sized tetrapod and tripod ding belonged to her, but the monumental tetrapod ding pair belonged to her son, Fu Ji. He apparently bestowed them at her funeral before his own untimely death. ${ }^{44}$ This difference represents the major distinction in rank between a future king and a living queen. Queens were not entitled to own or use monumental tetrapod ding, whereas kings and their heirs apparently were. Monumental tetrapod ding were the property of the highest-ranking males in Shang society.

No monumental tetrapod ding has been found in burials ranking below the top Jia rank (Table 2). Only medium- and small-sized tetrapod ding are found in Jia and ranks below Jia, underscoring that vessel size and type differed dramatically between royalty and lesser elite. Contrasts in terms of size (medium and small) and of number of ding in the Yi, Bing, and Ding ranks of burials corroborate the special status of square tetrapod as opposed to round tripod ding. Tripod ding as a rule are more numerous in burials of all these types, although their number decreases along with the status of the deceased. Tetrapod ding are typically outnumbered by tripod ding in burials (Table 3).

Medium- and small-sized square tetrapod ding appear during late Shang times in burials of Yi through Ding ranks, but were significantly outnumbered by round tripod ding. Medium- or small-sized tetrapod ding are found in all Yi through Ding burials of late Shang periods II, III, and IV, including Ya Chang's M54 at Huayuanzhuang, Ya Chi's M160 at Guojiazhuang, and Chang Zi Kou's M1 at Taiqinggong, Luyi, respectively (Table 3). A pair of two small-sized tetrapod ding belonged to the high-ranking military leaders Ya Chi and Ya Chang.

In the latest dated tomb, belonging to Chang $\mathrm{Zi} \mathrm{Kou,} \mathrm{two} \mathrm{different} \mathrm{sets} \mathrm{of}$ medium-sized tetrapod ding are mingqi versions created for burial alone (revealed by the low and soft quality of the bronze alloy used); five others were small in scale and 


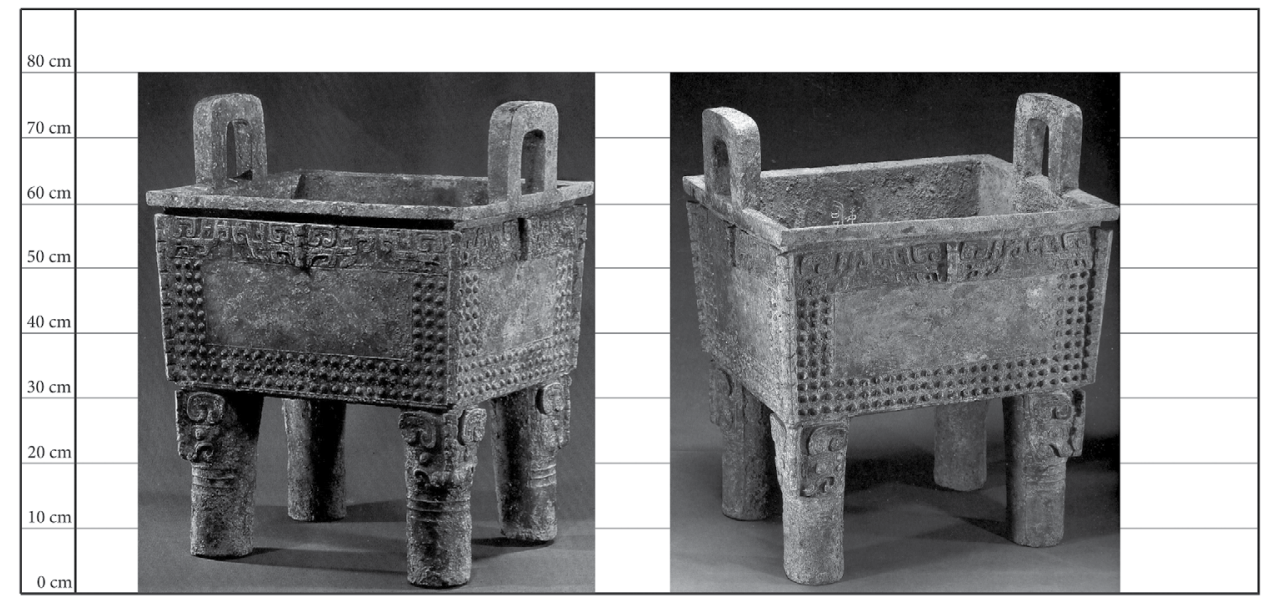

No. 789

No. 809

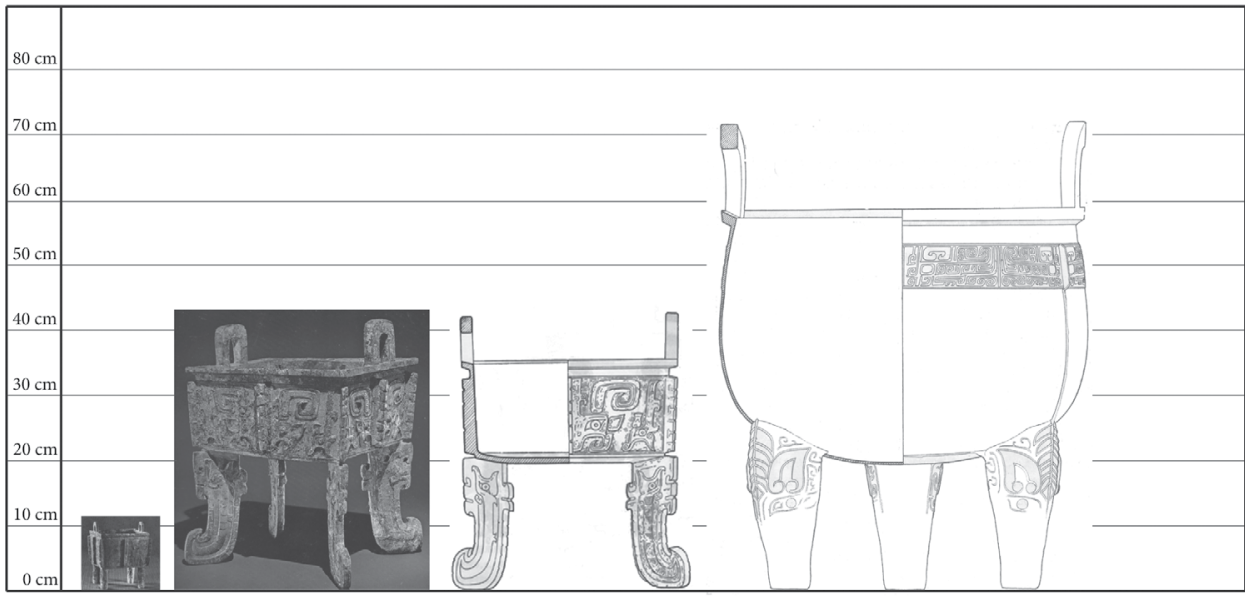

No. 834

No. 813

No. 812

No. 808

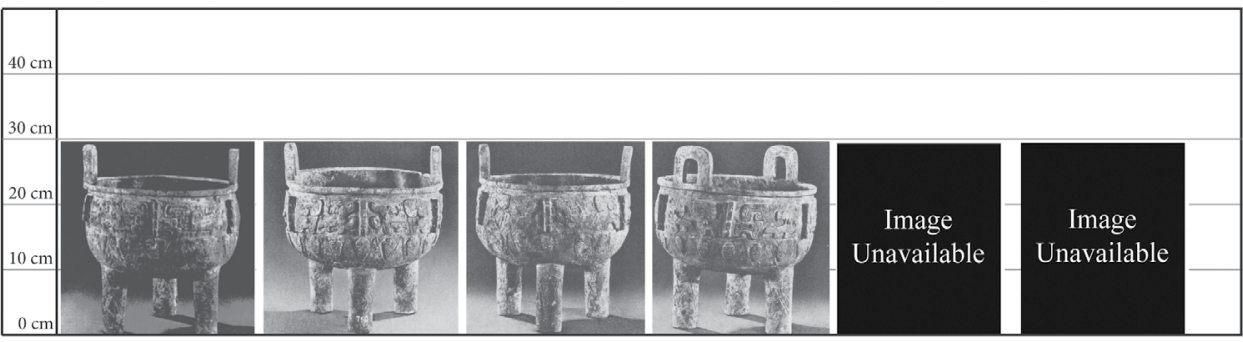

No. 821

No. 756

No. 814

No. 762

No. 758

No. 755

Fig. 13. Tetrapod and tripod ding sets from M5, Fu Zi's burial, Xiaotun, Anyang. 1st row: Hou Mu Xin inscribed tetrapod ding set, $80 \mathrm{~cm}$ tall (Nos. 789 and 809) $2^{\text {nd }}$ row: a small tetrapod ding (No. 834), pair of dragon-legged tetrapod ding over $40 \mathrm{~cm}$ tall (Nos. 813 and 812), a large tripod ding over $70 \mathrm{~cm}$ tall (No. 808)

$3^{\text {rd }}$ row: set of 6 tripod ding, each just under $30 \mathrm{~cm}$ tall (Nos. 821, 756, 814, 762, 758, 755) 


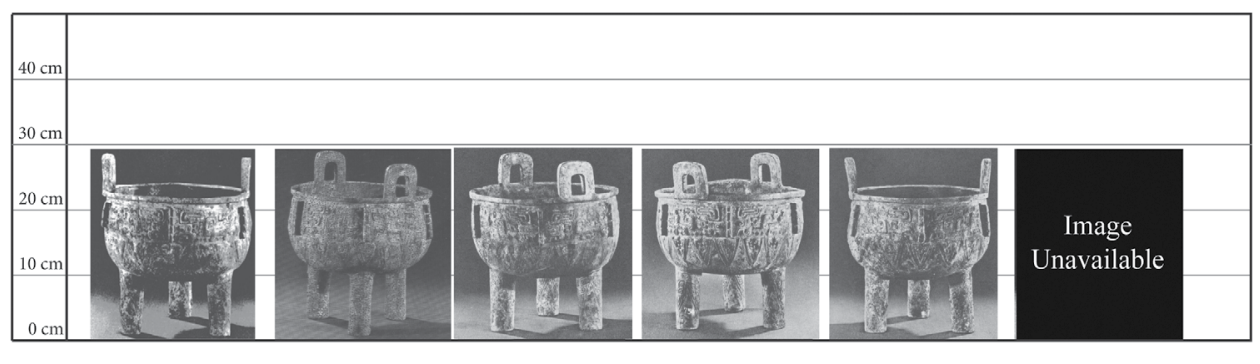

$\begin{array}{llllll}\text { No. } 815 & \text { No. } 760 & \text { No. } 761 & \text { No. } 754 & \text { No. } 759 & \text { No. } 757\end{array}$
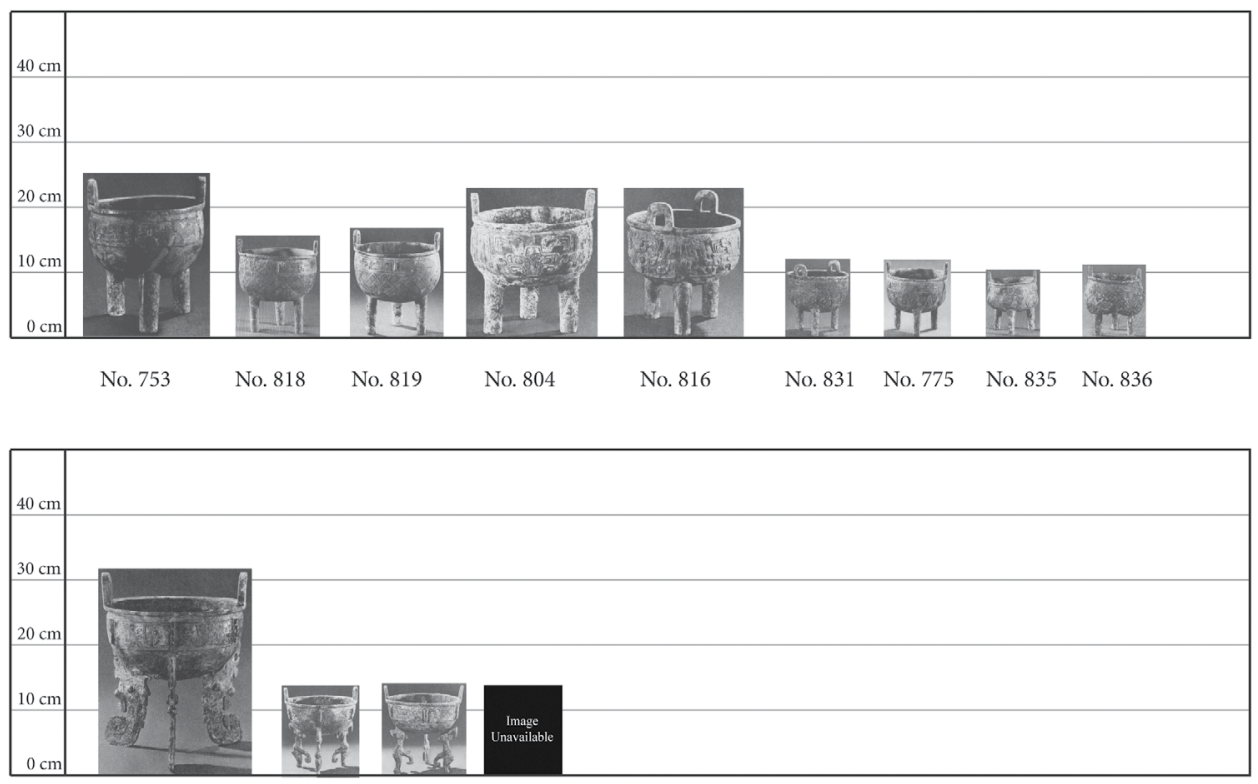

$\begin{array}{llll}\text { No. } 1173 & \text { No. } 776 & \text { No. } 1150 & \text { No. } 817\end{array}$

Fig. 13 (Continued)

$4^{\text {th }}$ row: set of 6 tripod ding just under $30 \mathrm{~cm}$ tall (Nos. 815, 760, 761, 754, 759, 757)

$5^{\text {th }}$ row: various tripod ding, including some pairs, from $10-25 \mathrm{~cm}$ tall (Nos. 753, $818 \& 819,804 \& 816$, $831 \& 775,835,836)$

$6^{\text {th }}$ row: 1 tripod ding with dragon legs over $30 \mathrm{~cm}$ tall $($ No. 1173) and a set of 3 tripod ding with bird legs, under $15 \mathrm{~cm}$ tall (Nos. 776, 1150, 817)

Sources: Row 1: No. 789 (Zhongguo 1997 vol. 2: pl. 39); all other images from Kaogusuo 1980 as follows. Row 1: No. 809 (colorpl. 1); Row 2: No. 834 (pl. 4.2); No. 813 (colorpl. 2.1); No. 812 (pl. 4.1); No. 808 (fig. 28, p. 41); Row 3: No. 821 (pl. 6.1); 756 (pl. 6.2); 814 (pl. 7.1); 762 (pl. 7.2); Row 4: No. 815 (pl. 8j.1); 760 (colorpl. 2.1), 761 (pl. 8.2), 754 (pl. 9.1), 759 (pl. 9.2); Row 5: No. 753 (pl. 10.1); 818 (pl. 11.1), 819 (pl. 11.2), 804 (pl. 10.2); 816 (pl. 10.3); 831 (pl. 11.3); 775 (pl. 11.4), 835 (pl. 12.2), 836 (pl. 12.1); Row 6: No. 1173 (fig. 26.3, p. 39), 776 (pl. 12.3); 1150 (pl. 12.4).

lidded (Fig. 14 and Table 3). Two other medium-sized tetrapod ding inscribed Xi Zi Sun 析子孙 were evidently gifts to the deceased. This high-ranking royal son of the Chang clan was evidently entitled to employ a set of five small-sized tetrapod ding and was provided with an additional set of two mingqi medium-sized tetrapod ding for the afterlife. This example again demonstrates that possession of tetrapod ding was distin- 

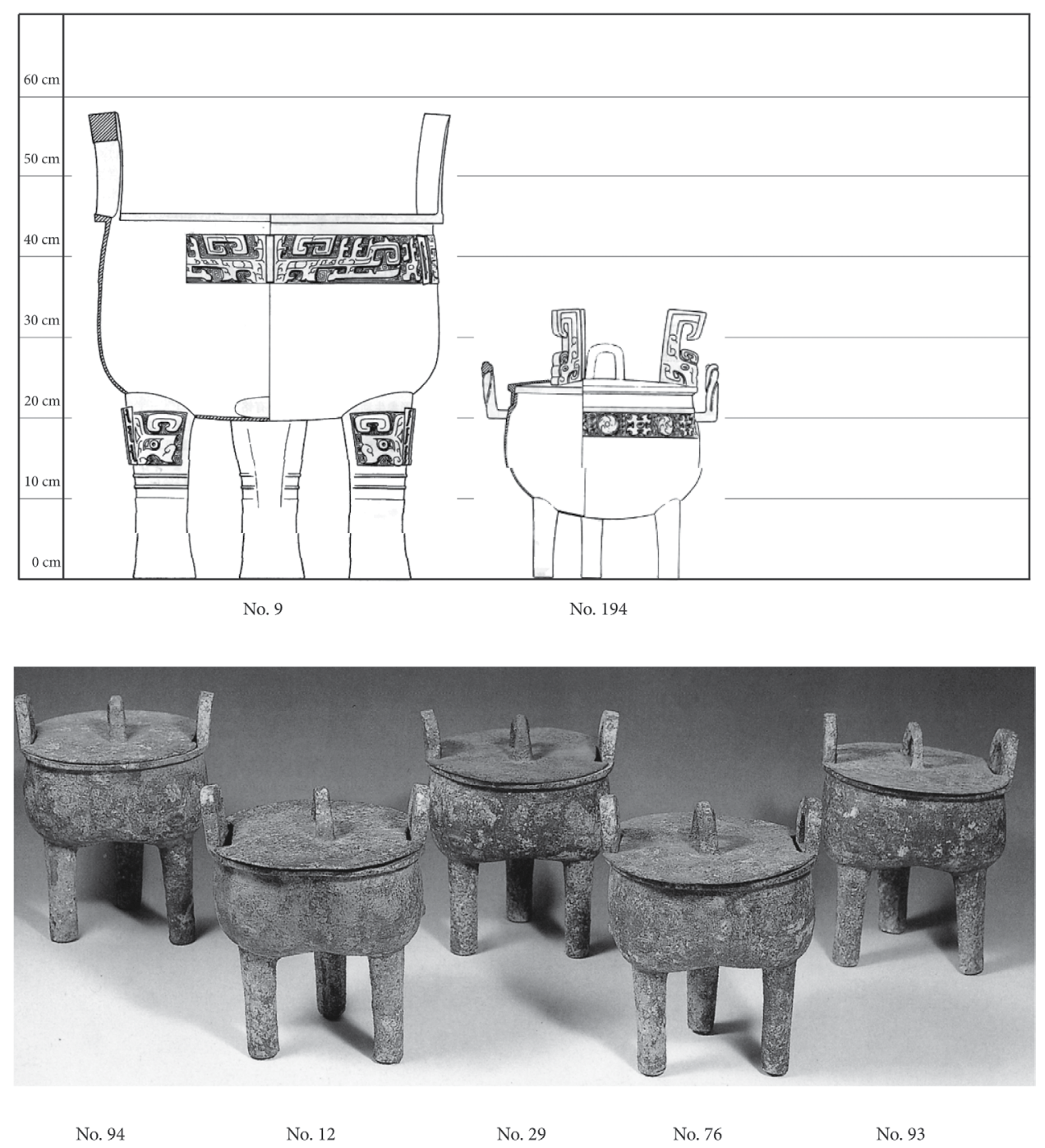

Fig. 14. Various tetrapod and tripod ding sets from M1, Chang Zi Kou's burial at Taiqinggong, Luyi, Henan.

Source: Henan 2000: pls. 32-34.

guished on the basis of rank. Yi through Ding ranking members of Shang society could own medium- and small-sized tetrapod ding. The large-scale tetrapod ding belonged strictly to the Jia class of rulers and their heirs, although they could be bequeathed to queen mothers after death. The smaller number of large-scale tetrapod ding produced in contrast with the more numerous tripod ding underlines the highly stratified social system of Shang bronze users.

Rulers were of course limited in number compared with members of other elite classes. This explains why fewer large-scale tetrapod ding exist. The number of royal tombs at Xibeigang identifies nine kings who ruled at Yinxu during the late Shang period (Soper 1966:26-27). ${ }^{45}$ This limited number of kingly burials sharply contrasts 


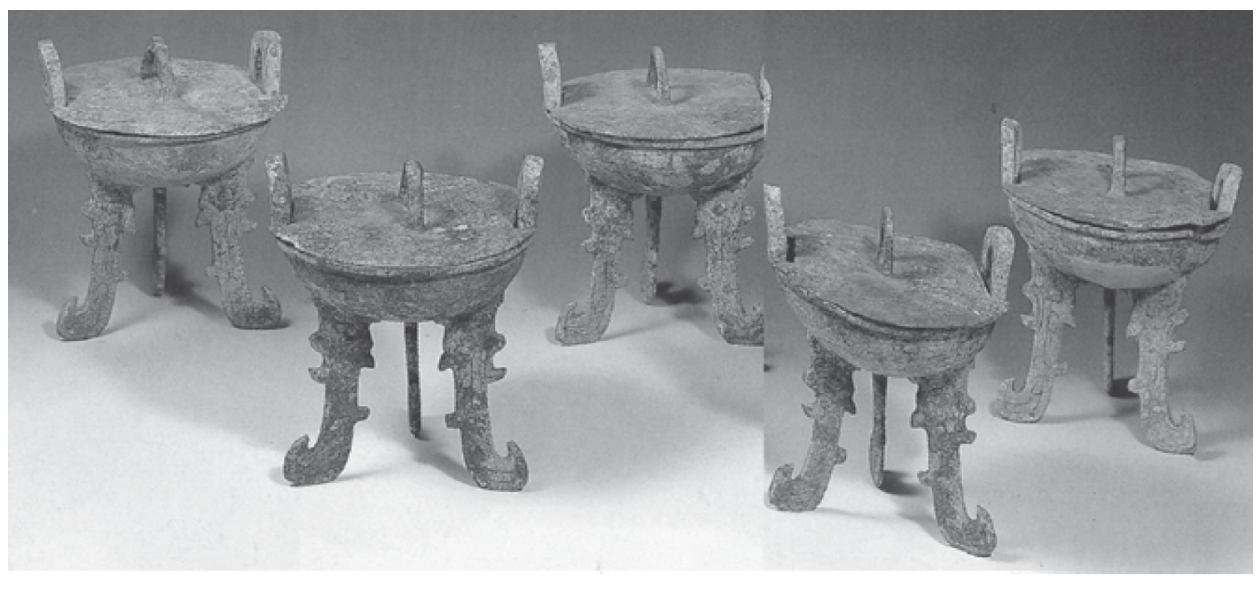

No. 6

No. 78

No. 80

No. 185

No. 91

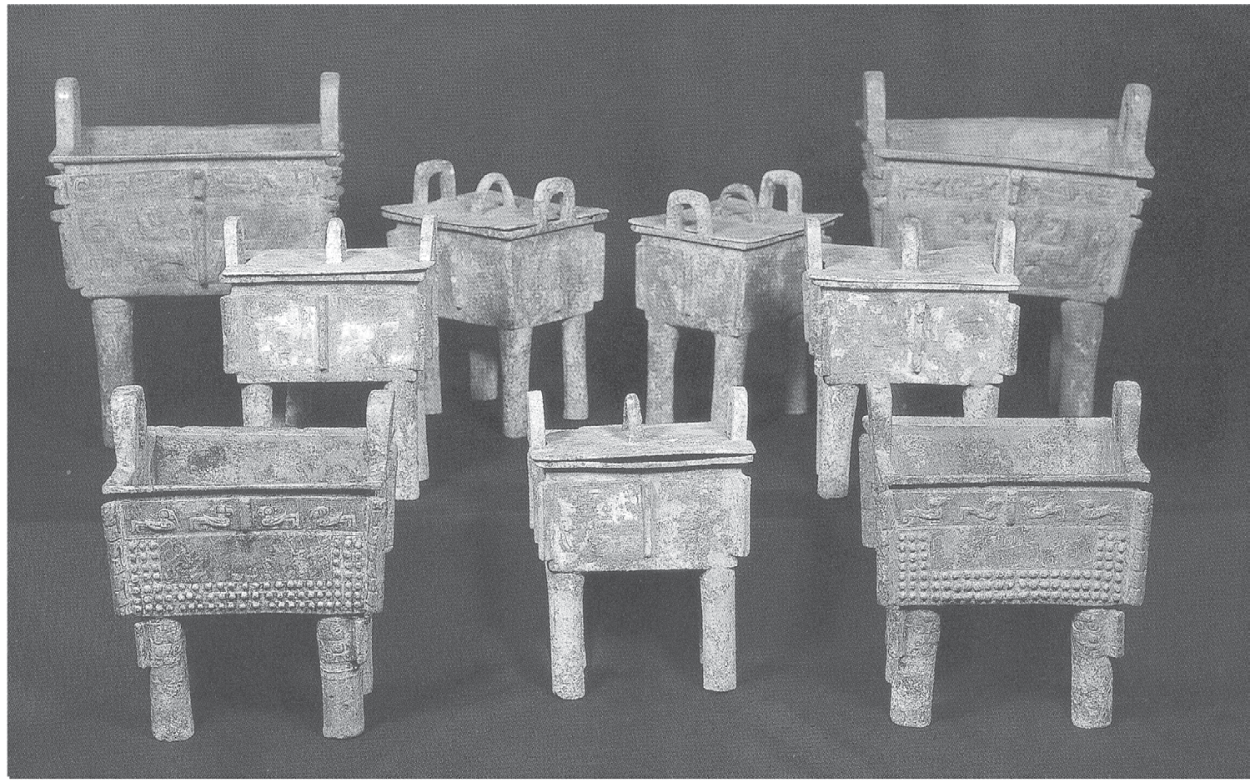

No. 46,87

measuring approx. $21.4 \mathrm{~cm}-21.6 \mathrm{~cm}$

No. 190,191 measuring approx. $27.6 \mathrm{~cm}-27.8 \mathrm{~cm}$

No. $4,77,88,95,186$

measuring $19.5 \mathrm{~cm}$

Fig. 14 (Continued)

with the approximately 1500 graves from the Western Sector cemetery atYinxu of late Shang date. Yang Xizhang (1983:55-59) identifies these graves as belonging to lineage cemeteries forming eight burial groups divided into two by an empty area. Clearly 1500 people who belonged to lineage burial groups differ dramatically in number from only nine ruling kings during the late Shang period at Yinxu in Anyang. None 
of the Western Sector burials were equipped with tetrapod ding, but tripod ding were found in most Ding and Wu status burials. This again underscores the difference between the few ruling elite and the population living under that royal Shang house.

\section{Hou $M u$ 后母 and $M u$ 母: Day-Names Designating Queens with Royal Male Offspring}

In addition to this evidence of monumental size, royal burial context, and monumental tetrapod ding use restricted to royalty, inscriptional data provide more evidence for the royal ownership of monumental tetrapod ding. The inscriptions on bronzes from the M5 and M260 burials are particularly instructive. Many of these inscriptions include the characters Hou $\mathrm{Mu}$ 后母 or $\mathrm{Mu}$ 母 alone. These day-names were used by queens who had produced royal male heirs.

In his study of burial inscriptions from Fu Zi's tomb, Cao Dingyun (2007:94-98) demonstrates that Hou 后 was an official title. In Shang bone inscriptions, Hou 后 (translated "Honorable" in this article; see Childs-Johnson 2013a) referred to royal house women who appeared to have been in charge of sacrifices. Hou is used similarly to the highest ranking title, Ya 亞, which identified male officials serving the royal Shang house. Other scholars have tried to equate the Hou title to various other roles such as queen (bi 妣), consort (peiou 配偶), wife (furen 夫人), or post-Shang female official (junhou 君后), but Cao argues that the bone evidence clearly indicates that Hou was the official title of a high-ranking woman, possibly in charge of sacrifices. Hou was used to refer to these female officials both while they were living and after death. ${ }^{46}$

$\mathrm{Mu}$ 母 and shi 通 were terms used posthumously to refer to royal queens and consorts in Shang times. Mu, here translated as Queen Mother, was a Shang period title primarily used by male offspring of kings and queens to address their biological mothers during royal rites of sacrifice (Chen 1956:447-451; Li X. 1977:161-163; Shima 1975 : 46-51; Song 2005 : 230-234). "Mu mother" in bone and bronze inscriptions specifically refers to a dead queen who gave birth to male offspring who would inherit the throne (Cao 2007: 92-94; Childs-Johnson 2004, 2007; Zhu 1990: 422-429). For example, Prince Fu Ji had cast and inscribed with his authorship a pair of monumental tetrapod ding that he bequeathed to his biological mother $\mathrm{Fu} \mathrm{Zi}$, calling her $\mathrm{Mu}$ after her death.

Two facts concerning queen mother (Hou) Mu Xin and crown prince Xiao Wang $\mathrm{Fu} \mathrm{Ji}$ are clear from the oracle bone and bronze vessel records of Shang times. First, both Fu Ji and his mother died during King Wu Ding's reign. Second, Fu Ji was the first successor of King Wu Ding. He is known in the royal registry of Shang times, in transmitted texts, and in bone inscriptions of Period I (King Wu Ding's era) as the Small King (Xiao Wang 小王), Crown Prince (太子), or King P. He is referred to as Xiong Ji (Brother Ji) in inscriptions from Period II (reign of $\mathrm{Zu}$ Geng and $\mathrm{Zu} \mathrm{Jia)}$ and as Small King Father Ji (Xiao Wang Fu Ji) in bone inscriptions from Period III (reign of Kang Ding). Obviously the concept of heir apparent or crown prince was operative in the hereditary titles of Shang times. ${ }^{47}$ Representative inscriptions include:

6. Heji 5570 Period 1: Should [I, the king] command the Small King . . o official ... ? 令... . 小王.... 臣... ? 
7. Heji 31546 Period 1: Crack-making on the jichou day Zi divined: Should the Small King P go hunting [at] Fu? 己丑子卜贞：小王䧃夫?

8. Heji 23354 Period II: Crack-making on the jichou day Xing divined: If the King visits on high Brother Ji with meat [sui] and bundled sacrifice [shu] will there be no otherworldly harm? 己丑卜行贞：王宾兄己岁束亡尤?

9. Heji 23120 Period II: Crack-making on the jichou day [Xing] divined: If the King receives the spirit of Brother Ji with Xie rite sacrifices will there be no otherworldly harm? Crack-making on the [gengchen] day Xing divined: If the [King] receives the spirit of Brother Geng with Xie rite sacrifices will there be no otherworldly harm? 己丑卜(行)贞：王宾兄己 协，(亡)尤? ... (更辰)卜行(贞)：(王)宾 兄更妿, 亡尤?

10. Heji 38278 Period III: . . Small King Father Ji? . . 小王父已?

The above inscriptions demonstrate that the Small King of Wu Ding (Period I) inscriptions (nos. 6 and 7) is the same as Small King Fu Ji of Period III inscriptions (no. 10) and Brother Ji of Period II inscriptions (nos. 8 and 9). The posthumous dayname Ji 己 used in Period II agrees with references in Periods III-V to Father Fu Ji and Grandfather $\mathrm{Zu} \mathrm{Ji}$, as well as with numerous transmitted texts that refer to a Ji as Xiao Zi Xiao Ji (Filial Son Filial Ji), the filial crown prince who belonged to the High Ancestral House of Yin (Cao [1995] 2007:114-115). ${ }^{48}$

That Fu Ji died during Wu Ding's reign is evident in a variety of inscriptions:

11. Heji 20023: Crack-making on the jiwei day: Should Prince Bi carry out exorcism to the Small King or not? Should Prince Bi carry out exorcism to the Middle Royal Son or not? 己未卜 : 子辟禦于小王不? 子辟禦[于]中子不?

12. Heji 5030: . . crack-making [on $\mathrm{x}-\mathrm{x}$ day] the King divined: Should [I] make sacrifice $[y o u]$ to the Small King? . . . 卜王贞：Ч(侑?)小王?

13. Heji 20022: Crack-making on the wuwu day: Should Shao make sacrifice [you]

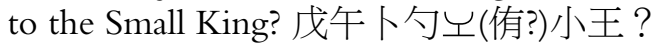

14. Heji 20021: Crack-making on the guiwei day: . . . Should [I] make offering to the Small King? 癸未卜 : . . 于 小王?

Sacrifices were seldom offered to living royalty, only to those that had died. Sacrifices offered to this Small King during Period I, including 禦 $y u$ exorcism and 侑 you-sacrifice, document that Fu Ji was deceased (Cao 2007:116-118).

Cao Dingyun (2007:117-122) has discovered other evidence demonstrating that Small King Fu Ji died during Wu Ding's era. Another name in bone inscriptions for this heir apparent is written with the graph $P$. The name $P$ appears in the term "Wang/ King or Royal P name" or simply as "P name." Based on comparative inscriptional data, this alternative name $P$ for the Small King Ji may be identified as his place of enfiefment and place name:

15. Heji 4222: If Shi Pan provides [X?] at Wan should King P be summoned? 師 船獻萬呼王P?

16. Heji 40859: Crack-making on geng- . . day: Will King P net 30 [hunted animals]? 庚 ....王P ... 擒三十 ... ?

17. Heji 10655 front: Crack-making on the renyin day Ke divined: Should King P [make offering] to Father ... ? 王寅壳贞：王际 . . . ?

18. Heji 14524: Should [Wang/King] P carry out exorcism to the He river god? ....陋于河?

19. Qianbian 8.72.1: On the bingshen day I [the King] cracked the bone: Should [Crown Prince/King] P shackle and trap wild boar? On the guisi day I [the King] 
cracked the bone: Should [Crown Prince/King] P shackle and trap wild boar (?) on this day? 丙申余卜 : 㯫? 癸已余卜㯫?

20. Heji 40689: P sent in four prepared tortoise plastrons for altar use. P示四.

23. Heji 20706 front: . . . the King divined: Should [I] not go out to King P to catch tiger?... 贞王：勿止在王䖎擒?

By Period IV, the Crown Prince, heir apparent is still called King P in receiving worship on $j i 己$ days in the schedule of royal house sacrifices in concordance with his posthumously assigned name:

24. Heji 3538: Crack-making on the jisi day: Should on this coming jimao day fermented spirits be offered to King (Wang) P? 己巳卜 : 来已枊酒王P?

25. Heji 34560: [Crack-making] on the jisi day: Should fermented spirits be offered to King (Wang) P? 己已[下] : 酒王P?

Apparently, the Small King Ji was not only addressed as Fu Ji but also addressed as King $P$ in royal house rites of sacrifice.

Finally, proof that Small King Ji was given the name $\mathrm{P}$ at birth includes two key inscriptions from Wu Ding's era (Cao $2007: 123)$ :

26. Heji Tie 127.1: Crack-making on the gengzi day, Que divined: Would Fu Zi have a child? 2nd month. 庚子卜殼贞：妇子有子?二月.

27. Heji Yi 620: Crack-making on the xinchou day Que divined: Will Fu Zi have a child? 3rd month. Crack-making on the xinchou day Huan divined: The King prognosticated, saying, [Fu] Zi will have Royal Son [or child named] P?. 辛丑卜殼贞： 妇子有子? 三月. 辛丑卜亘huan 贞：王占曰：子其有子p? 三月

Inscriptions nos. 26 and 27 demonstrate that $P$ was not only an alternate name for Xiao Wang Fu Ji, but was also a place name in Period I inscriptions. Number 27 shows that his father, King Wu Ding, bestowed the name upon his firstborn son. During Wu Ding's era, Fu Ji (Xiao Ji/Filial Ji of later texts) was not only referred to as Small King (Crown Prince Xiao Wang), but as King (Wang) P or simply P, and by his living father, as $\mathrm{Zi} \mathrm{P}$ or Royal Son P. ${ }^{49}$

The evidence that Fu Ji died after his mother during Wu Ding's era is based on inscriptions associated with the Shi named diviner group that can be dated after the Bin named diviner group. Fu Zi was worshipped as Hou Xin in Bin group divinations, which Cao $(2007: 126)$ dates earlier than certain Shi group divinations. Since Xiao Wang had died by the era of recorded Shi group divinations (Cao 2007:115116), he succeeded his mother in death.

Although the precise dates of their deaths are difficult to pinpoint, $\mathrm{Fu} \mathrm{Zi}$ and Small King Ji are known to have died during the middle or late period of Wu Ding's reign. That $\mathrm{Fu} \mathrm{Zi} \mathrm{died} \mathrm{at} \mathrm{this} \mathrm{time} \mathrm{is} \mathrm{well} \mathrm{documented} \mathrm{in} \mathrm{several} \mathrm{studies} \mathrm{of} \mathrm{inscriptions} \mathrm{relat-}$ ing to her activities and death during a royal hunt (Wang 1979; Wang et al. 1977). Inscriptions show that King Wu Ding mourned her death and divined about the potential for her divine marriage to Shang Di (God on High) or another of the highest ancestors from Shang history and myth (Childs-Johnson 2003:637-638). Since Small King Ji was the only heir apparent she produced and because $\mathrm{Zu}$ Geng and $\mathrm{Zu}$ Jia did not assume the throne until after Wu Ding died, the vessels in Fu Zi's burial M5 at Xiaotun inscribed Hou Mu Xin or Mu Xin could only have been offered by Small King Ji.

The honorific title Hou Mu (Honorable Queen Mother) along with her posthumous day-name is inscribed on the pair of monumental tetrapod ding (Fig. 10), a pair of refined gong vessels, and one tall square footed vessel from Fu Zi's tomb M5 (Kaogusuo 1980:37, fig. 25). All of these vessels had been owned and used by Small King 
Ji 小王己 before he gave them to her after her death (Cao 2007:118-122; ChildsJohnson 2003, 2007).${ }^{50}$ Although Hou is a title of official office, most likely the highest ranking one for royal house females (Childs-Johnson 2013a), Hou Mu Xin (Honorable Queen Mother Xin) is clearly the object of sacrifice; Mu Xin is Fu Zi's ritual and posthumous name, a name for a queen who has produced an heir to the king.

$\mathrm{Fu} \mathrm{Zi} \mathrm{could} \mathrm{not} \mathrm{herself} \mathrm{have} \mathrm{inscribed} \mathrm{a} \mathrm{vessel} \mathrm{with} \mathrm{her} \mathrm{own} \mathrm{posthumous} \mathrm{title.} \mathrm{Nor}$ would her husband have addressed her with the title Mother ( $\mathrm{Mu}$ 母). Ritual posthumous nomenclature observed strict rules. Wu Ding used the terms Hou Queen Xin (Hou Xin 后辛), Noble Lady Xin (Fu Xin 婦辛), Honorable Queen Noble Lady Zi (Hou Fu Zi 后婦子), or Noble Lady Zi (Fu Zi 婦子) to address his wife (Qian 5.9.6; Heji no. 2672; Childs-Johnson 2003:n11; 2007:19-20). None of these terms include the graph for Mother. Queen Mother Xin (Hou Mu Xin) can only be a posthumous title used by her son during worship of her as a royal ancestor, although Fu Ji's brothers also used it after they became kings. The large-scale tetrapod ding pair in M5 clearly had a specific ritual use as Small King Ji honored his mother by making sacrifices to her.

Another significant point concerns specification of the dead ancestor to whom sacrifice is made. Some ritual bronzes apparently could be used during multiple sacrifices on different days, as illustrated by the well-known examples unearthed from burials in the Western Sector cemetery at Anyang. Two large zun (M93:1,4) from burial M93, for example, are inscribed with three short dedicatory inscriptions including three different clan emblems followed by three different "day (ri 日) + daynames," as in “clan emblem ri yi 日乙,"“clan emblem ri xin 日辛,” and “clan emblem ri jia 日甲,” all of which are enclosed within a large ya graph 亚 (Kaogusuo 1979: 81, fig. 58). However, if a dead person to whom sacrifices were made was specified, then the vessel became limited in use to that single ancestral spirit (Fu Ji's mother in this case). A gu goblet inscribed "Hou Mu Xin" would only be used to offer alcoholic sacrifices to Hou $\mathrm{Mu} \mathrm{Xin}$; on the other hand, a jue tripod beaker inscribed "Fu Zi," the queen's living name, would imply that $\mathrm{Fu} \mathrm{Zi}$ used the vessel while she was alive to make sacrifices to one or more ancestral spirits.

The second example of a Hou Mu inscription identifying a queen mother by posthumous title is the name Hou Mu Wu 后母戊, or Honorable Queen Mother Wu, on the monumental tetrapod ding from M260 (Fig. 12). ${ }^{51}$ Based on the data from Fu Zi's burial and the fact that her son Fu Ji alone could use this form to address the queen mother who bore him, it is theorized that this other large-scale tetrapod ding similarly inscribed Honorable Queen Mother, followed by a posthumous day-name, Wu (Hou $\mathrm{Mu} \mathrm{Wu}$ ), was also restricted in use to a son in line to the throne. ${ }^{52}$ Hou $\mathrm{Mu} \mathrm{Wu}$ was most likely the mother of Wu Ding's third son, known posthumously as Zu Jia 祖 甲. ${ }^{53}$ Just as Fu Zi's son placed two large tetrapods in her tomb to placate her spirit in perpetuity, so Fu Jia (30th Shang king) probably put the largest monumental tetrapod ding known into the tomb of his mother. The so-called Wuguancun Tomb (M260) was entirely looted except for the $875 \mathrm{~kg}$ tetrapod ding, which was evidently too heavy to carry away. It is highly likely that the large-scale tetrapod ding inscribed Honorable Queen Mother Wu is another example of a ritually prescribed royal tetrapod cast by a Shang king (Zu Jia). His mother, King Wu Ding's third wife, was known posthumously in the royal ancestor cult as "Mother Wu (Mu Wu)" or "Ancestress Wu (Bi Wu)" (Shima 1975:551-552, 450-451). The most obvious scenario is that Zu Jia was alive at the time of his mother's funeral since he, like his brother $\mathrm{Zu} \mathrm{Ji}$, made a gift of a royal-sized rectangular tetrapod ding to his mother. It may have been a ritual rule 

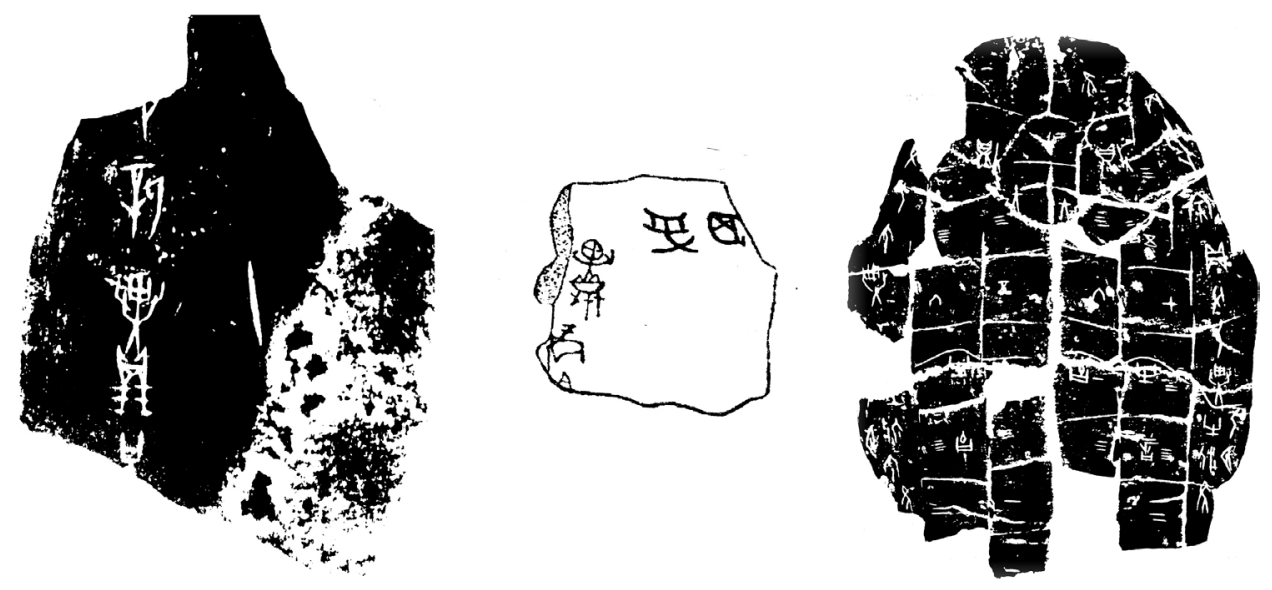

Fig. 15. The hewen "yiding" graph in late Shang and pre-Conquest Zhou bone inscriptions from Xiaotun, Anyang, Henan, and Zhouyuan, Shaanxi.

Sources: Heji 31000 (left); Wang 1984: fig. 14 H11:87 (center); Heji no. 2274 (right) (also see ChildsJohnson 2007: figure 8C, p. 58).

that all queen mothers of Shang date were to be buried with monumental tetrapod ding gifted by their royal sons. ${ }^{54}$

The royal title Honorable Queen Mother inscribed on monumental tetrapod ding is evidence that these vessels were strictly owned and used by heirs apparent or kings. The next section presents further inscriptional evidence supporting this contention.

\section{Yiding 異鼎: Metamorphically Empowered Tetrapod Ding in Shang and Western Zhou}

\section{Inscriptions}

Shang period oracle bone inscriptions often describe ding with the binome yiding 異 鼎 (Fig. 15). ${ }^{55}$ This inscriptional term is one of several pieces of evidence to identify the meaning of Shang ritual imagery as metamorphic (Childs-Johnson 1998, 2008). ${ }^{56}$ "Metamorphic" is also a term used elsewhere but with a completely different meaning, in describing, for example, artistic style of representation, not religion or belief (Wu 1995:50-52). The specialized term $y i$ 異 in bone and bronze inscriptions means “" to be empowered due to (spirit) metamorphosis' or 'to cause to undergo metamorphosis", (Childs-Johnson 2007). The yiding binome thus can be read as "the tetrapod ding invested with metamorphic power" or "the metamorphically empowered tetrapod ding" (Childs-Johnson 2008: 70-78).

Although there is no clear-cut distinction in bone inscriptional terminology between ritual bronze round tripod and square or rectangular tetrapod ding, the yiding binome most likely refers to the largest of the ding, which are tetrapod. Due to the large size and royal burial origins of all late Shang tetrapod ding, it appears that when the power of the ding ritual bronze was invoked, it was in reference to the largest and most powerful manifestation of this ding type. Various inscriptions make it clear that only the Shang king or an heir in the royal line of succession could receive or be invested with a yiding. Three significant bone inscriptions (discussed in Childs-Johnson 2008 : 71) illustrate this: 
28. Wang Fig. 114, p. 312: Will [I, the king] receive the [tetrapod] ding invested with metamorphic power? 其受異鼎? (H11:87)

29. Heji 31000: The bone was cracked: Should [I, the king] invoke spirit(s) with the new [tetrapod] yiding [ding invested with metamorphic power]? 卜新異鼎祝?

30. Heji 2274 (abbreviated): Crack-making on the bingzi day Bin divined: If FuYi (26th king) [Xiao Yi] causes spirit empowerment [metamorphosis], will it mean bestowing the power of the [tetrapod] ding vessel upon the King [his eldest son]? If Fu Yi does not cause spirit empowerment, will it mean not bestowing the [tetrapod] ding upon the King? 丙子卜賓貞父乙異惟鼎王? [貞] 父乙不異惟鼎王?

The last inscription is a specific reference to the dynastic empowerment of King Wu Ding. Dynastic empowerment is represented by the ability to divine. Being able to speak with ancestral spirits supports the king's royal status. The yiding queried about was likely similar in appearance to the two monumental tetrapods buried with $\mathrm{Fu} \mathrm{Zi}$ or the pair from M1004 that also belonged to her son, Fu Ji. These inscriptions appear to be clear-cut precursors to the legend of dynastic inheritance that became well known in Eastern Zhou and Han times. The legend says that the possession of nine ding bronze vessels is a sign of state authority and divine power.

The sacred and ritual association of yiding (metamorphically empowered tetrapod ding) with royalty continued during the early part of the Western Zhou period. For example, four identical inscriptions were cast on what is known as the Zuoce Da (Scribe Da) 作冊大 set (Fig. 16). This set consists of four small tetrapod ding that survive in different collections; it is not known how many small tetrapod ding were in the original set. All four are identical in form, décor, and inscription (Pope et al. $1967: 190-195) .{ }^{57}$ They are also close to the same size at approximately $27 \mathrm{~cm}$ tall $\times 20$ $\mathrm{cm}$ wide and weighing less than $4 \mathrm{~kg}$. The Freer example shown in Figure 16 is 26.7 $\mathrm{cm}$ tall $\times 19.7 \mathrm{~cm}$ wide and weighs $3.77 \mathrm{~kg}$. It is significant that these vessels are so small. They did not belong to a ruler, but to a high-ranking scribe. This again underscores the different rights of royalty and aristocracy to own monumental versus small tetrapod ding.

Zuoce Da or Royal Scribe Da was the name of the owner of the four vessels. He was allowed to commission their manufacture as an award from a duke who was probably the Duke of Zhou, the regent from 1042-1036 B.C.E. Zuoce Da received the reward after witnessing a major royal event: the Duke casting divinely empowered tetrapod yiding to honor King Cheng and King Wu of the early Zhou dynasty (ChildsJohnson 2008:73-74). As royal scribe employed by the Zhou court, Zuoce Da was evidently given the right to cast his own set of four (or more) small rectangular ding as an award for his participation in what must have been an awe-inspiring state ceremony. An identical inscription on all four Zuoce Da tetrapods reads as follows (Fig. 17):

When the Duke came to cast [in honor of] Cheng Wang and Wu Wang a yiding in the 4th month, 2nd quarter of the month, jichou day, the Duke awarded Zuoce (Scribe) Da a white horse. Da extolled the August Heavenly Governor Da Bao's (Great Protector's) grace. [Da] made for $\mathrm{Zu}$ (Ancestor) Ding (this) precious sacrificial vessel. Bird on the Perch (clan sign) Ce (Scribe) 公來鑄成主武王異鼎 (hewen) 惟四月即生霸已丑公商 (賞)作冊大白馬. 大揚皇天使大保定. 用作祖丁寶尊彝奃冊

Evidently the owner of the vessel had survived the end of the Shang era into the Western Zhou era, since "Bird on the Perch" was a Shang clan sign (Chou et al. 1977: 446-451; Zhongguo 1997, 4:3, pl. 9). Most scribes in the early Western Zhou period were elite relatives of Shang clans. ${ }^{58}$ They continued to observe sacrifices to 


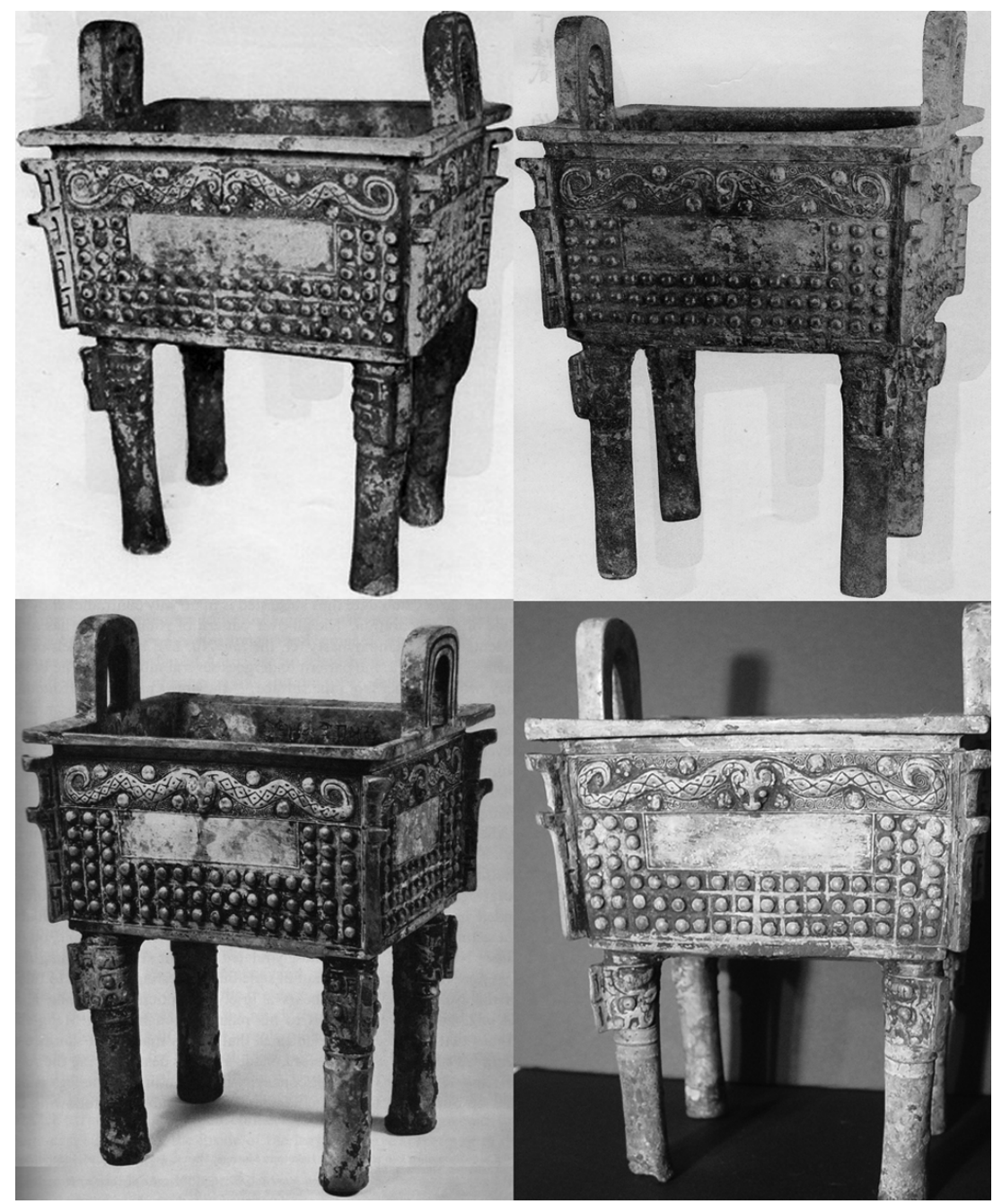

Fig. 16. Four identical Zuoce Da 作冊大 small tetrapod ding preserved at the Royal Palace Museum, Taiwan (2 in top row), Freer Gallery of Art, Washington, D.C. (lower left), and Hermitage Foundation Museum, Norfolk, Virginia (lower right).

Sources: Ku-kung 1958 vol. 2: pls. 62-63 (top row); Pope 1967 vol. 1: pl. 195 (lower right); and courtesy of the Hermitage Museum and Gardens, Sloane Collection, Norfolk, Virginia, 50-G-11 (lower left).

deceased royal Shang kinsmen, in this case to Ancestor Ding, who may have been Wen Ding, the third from the last king to rule at Anyang during the late Shang period.

Early Western Zhou kings evidently perpetuated Shang royal practice of identifying with metamorphic power. We can only ponder the huge scale and appearance of the yiding referred to in the inscription, the magically empowered vessels cast in honor of reigning Western Zhou kings. The inscription on the set of small tetrapod ding during the early Western Zhou period thus documents the continuation of Shang worship and ritual honoring deceased royal ancestors. The fact that large-scale ding pairs and smaller ding sets continued to be associated with elite power throughout the remainder of the Bronze Age (the Western and Eastern Zhou eras) further underscores 

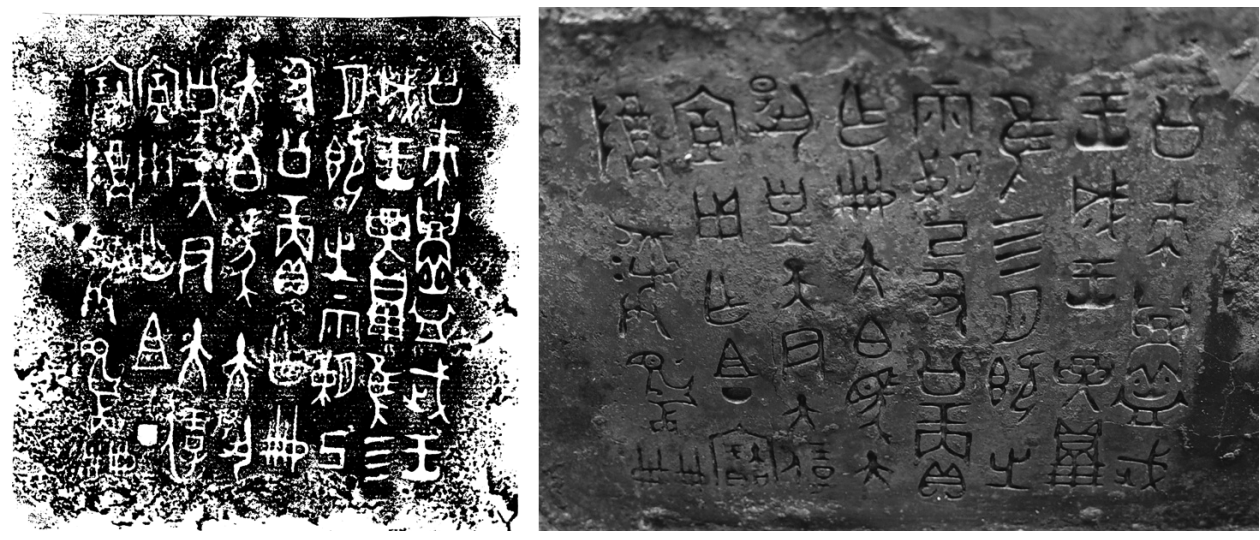

Fig. 17. Inscriptions on two vessels (from a set of small-scale Zuoce Da 作冊大 tetrapod bronze ding with hewen "yiding"), Western Zhou period, c. eleventh century B.C.E.

Sources: Freer Gallery rubbing (left) from Pope 1967 vol. 1: pl. 34; right courtesy of the Hermitage Museum and Gardens, Sloane Collection, Norfolk, Virginia, 50-G-11.

the significance of the ding vessel as a symbol of royal power in early Chinese history and myth. Other data supporting this are summarized below.

\section{AN EXCURSUS: MONUMENTAL DING AND DING VESSEL SETS AFTER THE SHANG}

Since ding continued to be the largest and most prominent vessel type created in sets in post-Shang times, the practice does not appear to be new but rather a continuation and revision of Shang precedent that prescribed who could own and use what ritual bronze vessels. According to Warring States dated texts, a ranked status system evolved called the ding zhifa 鼎制法 (ritual ding system) or dalao jiuding 大牢九鼎, meaning "great nine ding sacrifice of specially raised animal victims" (Yu 1995; Yu and Gao 1978-1979). Archaeological evidence suggests that the "great nine ding" system solidified sometime in the late tenth or ninth century B.C.E. This was the middle of the Western Zhou period (c. 1045-771 B.C.E.) approximately a century and a half after the Zhou conquest of Shang. ${ }^{59}$ According to Falkenhausen's reconstruction of the Zhou sumptuary system (2006:51, Table 4), the number and type of ritual bronzes that could be owned and used by different elite groups adhered to specific rules of "five ranks." Kings were the top-ranking group and were entitled to use nine ding. The second rank could have seven ding, the third rank five, and the fourth could have three or one. ${ }^{60}$ Other vessels, such as gui grain serving vessels, $h u$ liquor containers, jian water containers, chime bells, and other bronze items were also specified by number according to rank. Other vessel types were always subordinate to and smaller in number than the ding allowance. ${ }^{61}$

Burial finds of bronze sets corroborate this ranked use of bronzes during the tenth and ninth centuries and throughout the later Spring and Autumn and Warring States periods (c. tenth-fifth centuries B.C.E.). For example, the M1 burial at Baicaopo 白草 坡, Lingtai 灵台, Gansu 甘苏, identified as belonging to Earl Black (Hei Bo 黑伯) and dated sometime in the eleventh or tenth century B.C.E., included 7 ding, 1 yan, 2 zun, 1 zhi, 1 jiao, 1 jia, 1 he, 2 you, 3 gui (Gansu 1977:106-110). M253, a Yan 燕 state burial at Liulihe 流璃河, Beijing, Hebei in the late eleventh century B.C.E., included 


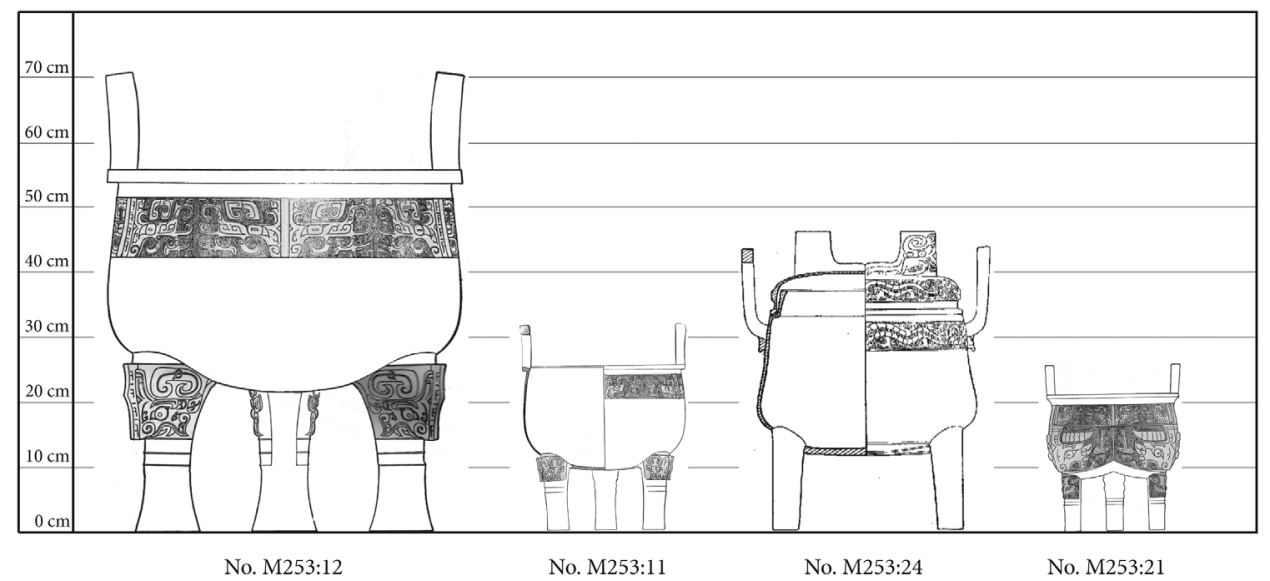

Fig. 18. Four of seven ding from M253, Liulihe, Beijing, Hebei. From left to right, a large Jin 堇 tripod ding, 62 cm (No. 253:12); a medium Yu 囯 tetrapod ding, 33 cm (No. 253:11); a medium Ya Qi 亚冪 ding, 38 cm (No. 253:24); and a medium Ya Ju Yang 亚拒羊 tripod ding, $25.6 \mathrm{~cm}$ (No. 253:21).

Source: Beijing 1995: fig. 25, p. 37, 36, 101-105.
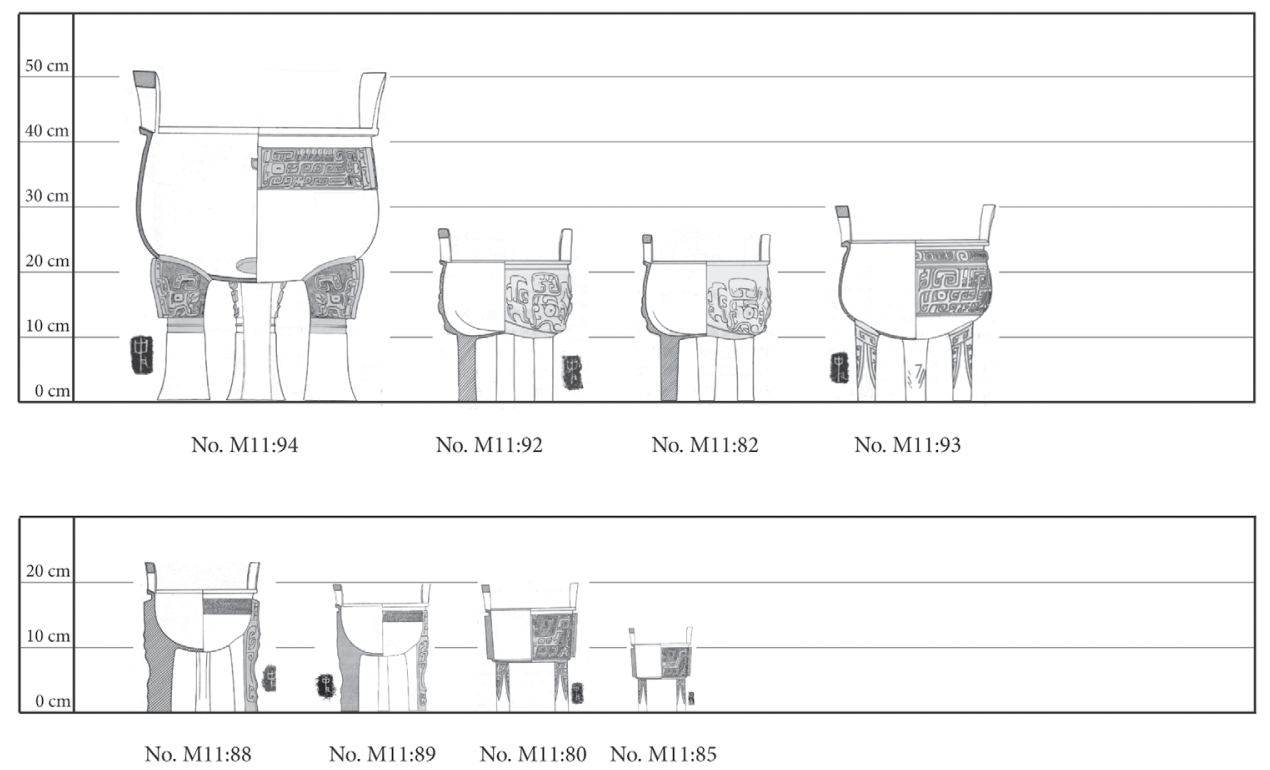

Fig. 19. Eight Shi 史 ding (6 tripods and 2 tetrapods) from a medium size tomb, M11 at Qianzhangda, Tengzhou, Shandong.

Source: Kaogusuo 2005 : 208-217.

6 ding, 2 gui, 4 li, 2 jue, 1 zhi, 1 zun, 1 yan, 2 you, 1 hu, 1 pan, and 1 he (Beijing 1995:31, 34-36; Fig. 18). Other representative burials include: M11 at Qianzhangda 前掌大, Tengzhou 滕州, Shandong, identified with Shi 史 (eleventh to tenth century B.C.E.) (Kaogusuo 2005; Fig. 19); Guo 虢 state burials at Sanmenxia 三門峡, Henan (ninth to mid-seventh century B.C.E.) (Henan 1999: 601-602) and Shangcunling 
上村岭, Henan (Kaogusuo 1959:28-31, 55, pl. 33:1, 4, fig. 4:3, pls. 45, 55 and chart p. 55: M1052, M1602 (ninth to eighth century B.C.E.); Zheng 郑 state burials at Xinzheng 新郑, Henan (eighth century B.C.E.) (Kuo-li and Henan 2001:43-46); Chu 楚 state burials (M2, M3) at Xiasi 下寺 (sixth century B.C.E.) (Henan et al. 1991: figs. 84, 156); the Minister Zhao of Jin burial 晋国赵卿 in Shanxi (fifth century B.C.E.) (Shanxi et al. 1996:17-21); and the Zeng Hou Yi 增侯乙 burial at Leigudun 擂鼓墩, Hubei (fifth century B.C.E.) (Hubei 1989:47-53; Fig. 20).

During the late eleventh through tenth centuries B.C.E. of the Western Zhou era, the time just after the Zhou conquest of Shang, changes gradually occurred in the bronze vessel repertoire and in the style of vessel shapes as well as in the representation of certain images (Rawson 1990). Nonetheless, ancestor worship continued to be the bedrock of the socio-religious system. Royal Shang ancestors gradually disappear from the sacrificial list of dead spirits in lieu of the ancestral line of the Zhou royal house, beginning with kings Wu and Cheng. An aggressive, savage style featuring dragon forms with spiral tails and feng phoenixes with a fan-shaped display of eyed tail feathers gradually replace the familiar wild animal mask of Shang times on ritual bronze vessels. The tripod jue libation vessel and $g u$ goblet also gradually disappear in the bronze repertoire and the gui grain vessel assumes new importance. The ding meat offering vessel nonetheless continues to stand out as the most significant one amidst bronzes, as corroborated, for example, by the yiding inscription of early Western Zhou date discussed above. The large square or rectangular tetrapods were gradually abandoned, however, as monumental round tripod ding came into favor.

Like their Shang predecessors, the monumental tripod ding of Western Zhou times vary in size, ranging in height from $94 \mathrm{~cm}$ to $122 \mathrm{~cm}$ tall (Li 1994: pls. 3, 10-11, 16-17, 21). Many of the large tripod ding of the late eleventh through ninth century B.C.E. date have historically well-known inscriptions, including the Yu 孟 ding pair dated to Kang Wang 康王 (1008-98 в.с.E.) (Shaanxi Bronzes: pl. 21); the Yu 旗 ding dated to Kang Wang (Shaanxi Bronzes: pl. 22); (Li 1994: pls. 21-22,); the Shi Zai 師 茛 ding dated to Gong Wang 共王 (936-922 в.C.E.) (Li 1994: pl. 26); the 93.1 cm tall Da Ke 大克 ding dated to Xiao Wang 孝王 (899-889 в.C.E.) (Li 1994: pl. 31); and the $51 \mathrm{~cm}$ tall Mao Gong 毛公 ding dated to Li Wang 厘王 (871-828 B.C.E.) (Li 1994: pl. 34). Most of the latter vessels were not excavated but were acquired and handed down over the ages and now are found in Chinese museums and collections.

Although only the Yu ding are known as a pair (Yu 1995:189), it is probable that the many other large single tripod ding now preserved in museums were originally part of a pair or set. There is increased archaeological evidence for ding continuing to appear in pairs or sets beyond Shang times. Excavated ding usually appear in sets of 5, 7 (second rank below king), or 9 (king status) (Li 1985 : 50, 69). Two ding in sets from the richest burials may be singled out in size, as larger than other ding and all other vessels, indicating that pairing was still important to the largest and most elite cast royal ding type. For example, the fifth century B.C.E. set belonging to Marquis Yi of Zeng at Leigudun, Suixian 随县, Hubei, include two that are the largest (57 and 64.6 $\mathrm{cm}$ tall) compared to two other sets of 9 ding that are identical in form and décor, though smaller (Hubei 1989: 189-203, pls. 23, 50-54; Fig. 20). ${ }^{62}$ Marquis Yi of Zeng (Zeng Hou Yi), a Chu vassal, evidently arrogated to himself the emblems of Zhou kings.

Although no Western Zhou royal burials have yet been excavated, the excavated burials mentioned above and those of the later Eastern Zhou period testify to the 


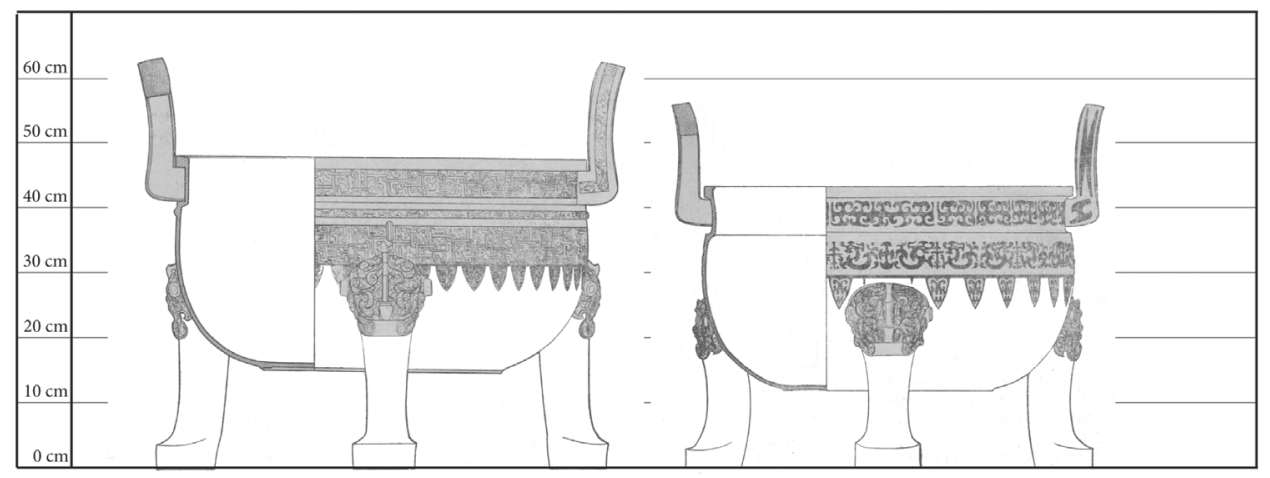

No. C96

No. C97

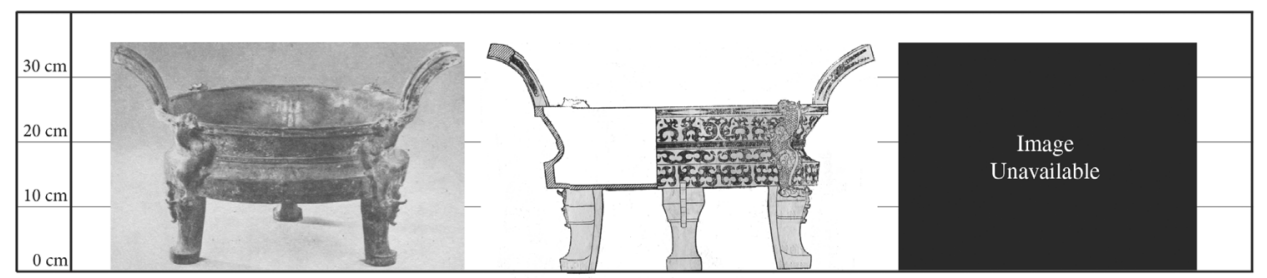

No. C88

No. C89

Nos. C87, C90, C91,

C92, C93, C94, C95

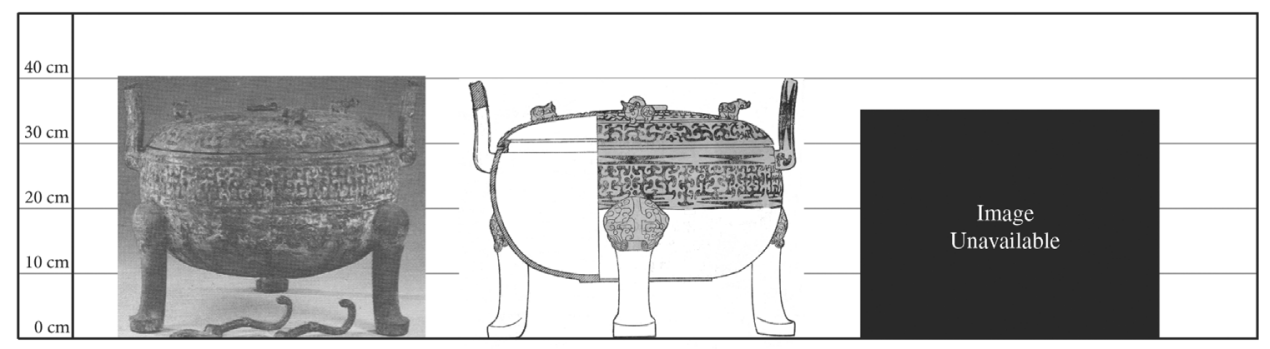

No. C101

No. C98

Nos. C99, C100, C104,

and 4 damaged (unlisted)

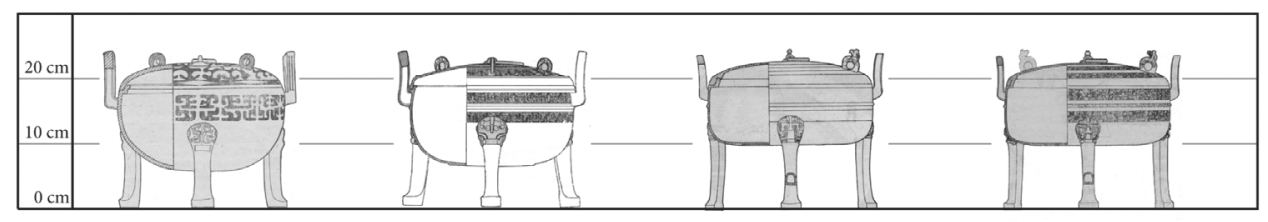

No. C103

No. C102

No. C235

No. $\mathrm{C} 236$

Fig. 20. Zeng Hou Yi 曾候乙 ding sets from Zeng Hou Yi tomb at Leigudun, Suixian, Hubei.

Row 1: The two biggest ding: C96 $64.2 \mathrm{~cm}$ (left) and C97 $50.2 \mathrm{~cm}$ (right).

Row 2: Set of 9 ding 35-36 cm. tall, represented here by C88 $35.3 \mathrm{~cm}$ (photograph left) and C89 35.2 $\mathrm{cm}$ (drawing center). No images have been published of the other 7 ding in the set (Nos. C87 $35.5 \mathrm{~cm}$, C90 $36.0 \mathrm{~cm}$, C91 $35.0 \mathrm{~cm}$, C92 $35.5 \mathrm{~cm}$, C93 $35.7 \mathrm{~cm}$, C94 $35.3 \mathrm{~cm}$, C95 $35.6 \mathrm{~cm}$ ).

Row 3: Set of 9 ding 39-40 cm tall, represented here by C101 $40 \mathrm{~cm}$ (photograph left) and C98 $39.3 \mathrm{~cm}$ (drawing center). No images have been published of the other 7 ding in the set (Nos. C99 $39.7 \mathrm{~cm}, \mathrm{C} 100$ $39.2 \mathrm{~cm}, \mathrm{C} 10440 \mathrm{~cm}$, and 4 damaged, unlisted). 
Fig. 20 (Continued)

Row 4: (left to right) Pair of tripod ding, C103 $23.2 \mathrm{~cm}$ and C102 $20.6 \mathrm{~cm}$; pair of tripod ding, both 26.3 $\mathrm{cm}, \mathrm{C} 235$ and C236.

Source: All from Hubei Bowuguan 1989 vol. 2

Row 1: C96 (left) drawing Fig. 91, p. 190 and see colorpl. 7.1 and pl. 50.1; C97 (right) drawing Fig. 92, p. 192 and see pl. 50.2 .

Row 2: C88 (left) colorpl. 7.2 and pl. 51.1; C89 (center) Fig. 96, p. 194; measurements for all 9 ding from chart 25, p. 194.

Row 3: C101 (left) pl. 52.1; C98 (center) Figure 97, p. 195; measurements from chart 26, p. 197.

Row 4: C103 (far left) Figure 99, p. 109 and see pl. 53.1; C102 (center left) Figure 101, p. 200 and see pl. 53.2; C235 (center right) Figure 102, p. 201 and see pl. 54.1; C236 (far right), Figure 103, p. 202.

Note: Other supplementary and smaller ding-shaped bronze vessels, not illustrated here, include a set of 10 averaging 20-21 cm, Nos. C113-121 \& C136 (C121 fig. 113.1, p. 213; also see pls. 56.1-2; measurements in chart 31, p. 214); a small mouth ding, C185 $38.5 \mathrm{~cm}$ (fig. 134, p. 237 and pl. 76.1); and a yanding C142 $40 \mathrm{~cm}$ (fig. 135, p. 239 and pl. 76.3).

continuing tradition, initiated by the creation of bronze vessel sets to identify status and position during the Shang period. The Marquis Yi of Zeng inscribes the two large tripod ding “曾侯乙作持用终 Marquis Yi of Zeng made these vessels to be used forever in sacrifice"; the other sets of nine ding are similarly inscribed (Hubei 1989:193, 196).

\section{MONUMENTAL TETRAPOD DING AT MILITARY OUTPOSTS CONTROLLED BY ROYAL HOUSE PRINCES}

The discovery of royal-sized tetrapod ding at capital and regional Shang sites is geographically significant in suggesting that early Shang rulers extended their economic and military power well beyond their Yellow River valley center in central Henan. Their distribution further implies that the Shang advertised and maintained royal power not only through building large settlements and military defenses, but also by casting major bronzes as symbols of their authority. The tetrapod ding from the capital site of Zhengzhou and regional sites of Pinglu and Xin'gan are all larger in scale and heavier in weight than any other types of extant early Shang bronze vessels (Figs. 8 and 9). All Zhengzhou examples were unearthed from caches. The Xin'gan examples in Jiangxi appear to belong to a burial that was elite, and the Pinglu vessels in Shanxi appear to be associated with a early Shang period settlement that was also significant in status.

In casting technique and artistic form, the bronze vessels from the Pinglu site are entirely consistent with early Shang examples that emanated from the capital center at Zhengzhou. They were cast in one or more pours using the piece mold casting technique (Jiangxi et al. 1997:293-298; and personal examination). The large Pinglu tetrapod is virtually identical in type to both South Zhangsai (Duling nos. 1 and 2) tetrapod ding at Erligang. Other vessels from Pinglu, such as the lei bronze (37 cm tall) and two jue (16.2 and $18 \mathrm{~cm}$ ) are comparable with metropolitan Erligang types (Henan 2001 : 28-29, pl. 31). Two large-scale round tripod ding from Pinglu are 70 and $73 \mathrm{~cm}$ tall, only 10-13 cm shorter than the tetrapod ding (Wei Si 1992:19); they are otherwise comparable in all respects to the $77.3 \mathrm{~cm}$ tall large tripod ding from the Zhengzhou cache at Moslem Bakery in Xiangyang (Henan 1999:86-87, fig. 61:3). Although large-scale tripod ding are never as large as the largest tetrapod ding, pairs of differing sizes of the tripods do exist in the Shang bronze vessel repertoire (Figs. 16, 24). ${ }^{63}$ 
Because the Pinglu vessels are metropolitan in style and casting technique, it is evident that this area was in direct contact with the capital at Erligang. Based on bone inscriptional and related data, studies of the social and political composition of the late Shang indicate that the kingdom had a complex and sophisticated administrative structure (Cao 2007; Liu 2004; Song 2005; Yang 1992). It had a pyramidal command center and extensive diplomatic connections in all directions that took advantage of six major routes: south and southeast to the Huai River valley and Renfang, then Wucheng, Jiangxi, Hubei, and Hunan; northeast to Yidu, Shandong; northwest to Shaanxi and the Wei River valley; northwest to the Taihang range, Gongfang, and Tufang; and northeast to Liaoning and Hebei (Peng 1988:269; Song 2005, 1:281293). ${ }^{64}$ Pinglu most likely served as a major nearby outpost protecting the northwest flank of the early Shang capital. The Pinglu tetrapod ding may well have once belonged to a royal prince who transported the vessel there when he was delegated to settle and protect the area. Shang kings and royal house officials were well-honed travelers who frequently left the capital, Da Yi Shang (Great City/Settlement Shang), to hunt, raise troops, conduct military training, make field or crop inspections, collect tribute, attack their neighbors, trade with others, or settle new areas, as related in late Shang bone inscriptions. ${ }^{65}$ Noblemen were regularly delegated to inspect and raise troops from friendly $y i$ 邑 cities throughout the kingdom. While traveling, they camped at secure waystations built along frequently traveled routes (Song 2005:195196, 285-287). The king's delegates or messengers (shi ren 使人) brought back reports from near and far lands (Song 2005:290-294). Messengers and delegates were predominantly $z i$ 子 princes whose status varied depending on whether they held high military rank (indicated by the title $y a$ 亞) or high official rank (the title bo 伯). ${ }^{66}$ The Pinglu monumental tetrapod most likely was the royal property of a prince who later became a Shang king at Zhengzhou, possibly Da Ding (8th king) or Yong Ji (14th king), the last early Shang king. ${ }^{67}$

As with the Pinglu bronzes, those unearthed at the Erligang period regional site of Panlongcheng near Wuhan in Hubei are also completely metropolitan in style, indicating direct metropolitan contact and control. This is evidence that these areas were under royal command from the northern capital at Erligang, Zhengzhou. Unlike Pinglu and Xin'gan, Panlongcheng has no burials that include large-scale tetrapod ding. ${ }^{68}$ Burial goods and bronzes unearthed from the Panlongcheng burials constitute primarily what is classified as third- and fourth-rank burials, that is, Bing and Ding types identifying elite military personnel (Table 2). Corroborating this is the fact that every excavated burial at Panlongcheng contained some form of bronze, stone, or jade weapon (primarily ge-dagger axes) (Hubei 2001 : 502, 505-516, charts 1-3). Bronze vessels and weapons were locally cast at Panlongcheng, as suggested by the remains of bronze workshops at Yangjiawan, Yangjiazui, and Wangjiazui, and remains associated with casting and melting bronze (Hubei 2001:406-409, 499, 503). Since no royal burials or tetrapod ding of the first rank have been found at Panlongcheng and most burials are associated with ranks of third- or fourth-rank status, the site seems to have been subordinate to Pinglu and Xin'gan. It nevertheless occupied a critical defensive location, operating as a fort protecting transport of copper, lead, and tin ingots and other southern goods on the Yangzi River. ${ }^{69}$

The bronze remains at Xin'gan reveal more about Erligang period production of sacred ritual bronze vessels far from the capital at Erligang. As with Panlongcheng, bronzes were cast on site. Yet the large-scale tetrapod ding and bronzes from Xin'gan 
differ from the Pinglu example and from Panlongcheng vessels in that although they manifest metropolitan influence in casting technique and typology, they reveal a stylistic and formal whimsy that seems entirely local in expression. Xin'gan appears to have been settled by royalty who exercised more independence than their contemporaries at the Shang period settlements in Hubei (Panlongcheng) and Shanxi (Pinglu) due to their considerable distance from the northern capital at Erligang.

Casting techniques and the formal attributes of the tetrapod ding and other vessels from the large burial at Xin'gan may be used to characterize both differences and similarities with Erligang. Xin'gan tetrapod ding are based on Erligang prototypes and reflect Shang ritual practice and polity, but are set apart by a taste for more cast-on attachments and certain whimsical interpretations of form. Three styles of bronzes have been identified in the Xin'gan burial. One is consistent with early to middle Shang style and casting techniques at Erligang, and may represent imports from the Zhengzhou metropolis. The second involved reworking metropolitan Erligang-style imported or transported vessels by adding new parts such as legs or handles. The third style is entirely local and idiosyncratic (Jiangxi et al. 1997:192-203).

The composition of the bronze alloy and casting technique used at Xin'gan are consistent with the model set in Zhengzhou (Jiangxi et al. 1997:292-300). The Xin'gan vessels contain the high radiogenic lead found in distant Sanxingdui vessels in Sichuan, as well as Hubei, Hunan, Three Gorges, Anhui, Shaanxi, and metropolitan Zhengzhou vessels from Henan sites (Jiangxi et al. 1997:249; Jin 2003; Jin et al. 1994). Furthermore, all of the tetrapod ding at Xin'gan were cast using the piece-mold clay technique composed of inner model parts and outer piece molds first established in Erligang (Jiangxi et al. $1997: 289-300) .{ }^{70}$ The Erligang method of casting is evident not only in the number of clay molds and models used to cast tetrapod ding but in the number of pourings of metal in connection with casting on or casting in methods. This is illustrated by the four large, square tetrapod ding from South Shuncheng Street in Erligang (Li J. 1999; Li and Guo 1999). Seen in figures 6 and 7 of Li Jinghua (1999), their progression in casting method typifies the manufacture of the same vessel type at Xin'gan. The H1:3 and H1:4 tetrapod ding represent the earliest examples of cast monumental tetrapod ding from the Erligang site; $\mathrm{H}: 2$ and $\mathrm{H}: 1$ in that order represent successive cast examples of the type. H:1, the largest and most refined, is mimicked in the creation of the two largest examples from Xin'gan, XGM (Xingan $\mathrm{Mu}$ ):8 and XGM:9 (Fig. 9).

The authors of the Jiangxi Xin'gan report (Jiangxi and Ruichang 1997:258-260, 289-290, 293-298) compare the latter Xin'gan tetrapods to the four tetrapods from Erligang, two almost identical pairs from South Zhangsai Street (Fig. 4), and the Moslem Grocery caches (Fig. 5). The basic process of casting large-scale tetrapods from Erligang, as represented by the example from South Zhangsai Street (Duling), involved two major stages, the creation of molds and the casting of the parts of the ding. Mold pieces totaled 19, with 5 core parts, including: 1) a 2-piece bottom mold carrying a cross-shaped clay core for reinforcement; 2) 4 walls consisting of 5 clay molds and 1 clay core; and 3) 4 legs consisting of 12 clay molds and 4 clay cores. After the molds were made, the parts were cast in 6 separate pours and parts were cast onto each other in 5 separate pours of molten bronze, following a 3 -step procedure: 1) the bottom part of the ding was cast; 2) the 4 walls and handles were cast and joined to the base; and 3) the 4 feet were cast and then cast onto the bottom part of the ding (Jiangxi and Ruichang 1997:290; Li and Guo 1999:112-124, figs. 1-7). The creation 
of tetrapod ding at Xin'gan involved more molds and separate casts because of the addition of ear ornaments (in the shape of tigers) and flanges (in the shape of curls). Casters at both sites used clay for both mold and model parts and metal for spacers designed to hold the mold and model together at the time of casting. The authors of the Xin'gan report suggest that the common use of metal spacers at Xin'gan demonstrates that this innovation arose in the south (Jiangxi and Ruichang 1997:294-297; exemplified by XDM:13, 38; XDM:38, 57; XDM:49, 69, 298). However, the earliest use of metal spacers is apparent in the earliest examples of tetrapod ding from the cache at South Shuncheng Street at Erligang. Most of the earliest bronze vessels from the Erligang period found in collections also employed metal spacers (Gettens 1969, $2: 98-106) .^{71}$

Xin'gan casters sometimes made distinctive local interpretations to the form of ding. One unusual example is XDM:13, a medium-sized tetrapod ding with a pullout drawer at the base of its belly (Jiangxi and Ruichang 1997:38, 45, fig. 24). This drawer appears to have been used for burning coals, as was practiced later during the early Western and middle Western Zhou periods in Shaanxi (Li 1994: pls. 13, 29). ${ }^{72}$ The most obvious major difference between Zhengzhou tetrapod ding and Jiangxi Xin'gan tetrapod ding is stylistic. This tendency is particularly noticeable in attaching small animals to handles and shoulders of ding and in portraying the animals representationally rather than in the abstract. For example, the two large-scale tetrapod ding XDM: 8 and XDM: 9 shown in Figure 9 are stylistically, technically, and compositionally comparable to early Shang tetrapod types at Zhengzhou in terms of casting technique, alloy, and form, but have added accoutrements such as the recumbent tiger attachments on the upper surface of the handles. The recumbent tiger, recumbent crested bird, and reversed deer head fixtures on handles or rims are distinctive to Xin'gan and not characteristic of metropolitan vessels of the north. ${ }^{73}$ In short, Xin'gan peoples utilized early Shang technology to cast bronzes according to metropolitan models yet demonstrated an independent flair in creating their own distinctive and idiosyncratic interpretations that typified southern taste. ${ }^{74}$

Aside from these idiosyncratic local features, Xin'gan also shares certain local cultural features with other southern sites, including Panlongcheng in Hubei and neighboring Wucheng 吳城 in Zhangshu 樟樹, Jiangxi. Ceramics, stonewares, protoporcelain types, copies of ceramic vessel types in bronze, and certain emblems incised on vessels connect Xin'gan and Wucheng (Jiangxi and Ruichang 1997: 191; Jiangxi and Zhangshushi 2005:496-498). Ceramics from Panlongcheng are mostly local types and include stonewares, possibly imported from Xin'gan manufacturing centers (Hubei 2001: 496, fig. 348, 497-498). In the early Shang walled site of Wucheng, just $20 \mathrm{~km}$ away from Xin'gan (Dayangzhou), there is evidence that the inhabitants were bronze users. Wucheng is therefore frequently cited as a major Shang settlement that defended the route to valuable ores from mines at nearby Tongling in Ruicheng (Jiangxi and Ruichang 1997:191, 192-203; Jiangxi and Zhangshushi 2005:420-425, 454-458, pls. 14-15; Peng 2010:23-26; Song 2005, $1: 284) .^{75}$

Despite stylistic differences and significant lacuna in the archaeological record, Xin'gan was obviously a major southeastern center of Shang authority. It observed royal practices while exhibiting independence, signified by idiosyncratic stylistic variations in casting bronzes as well as in the creation of local types of stonewares and ceramics. Although the dating of the large-scale burial to early through middle Shang 
or early through late Shang periods has been questioned (Jiangxi and Ruichang 1997:326-333), the two monumental tetrapod ding (XDM:8, 9) clearly depend upon the stimulus and precedent set by metropolitan versions represented at Erligang that range in date before the end of Erligang Period III. The four other tetrapod ding of more modest size at Xin'gan (XDM:10-13) are variations of the type and represent experimentation by Xin'gan metallurgists. This suggests that a Shang prince and military hero of early Shang date was sent with a contingent of Shang troops and professionals knowledgeable about casting bronze to this site to set up a command center. The prince was probably sent to oversee control of the route south to mines in Ruicheng in Jiangxi, in Hubei and Hunan, and farther south and west in Sichuan and Yunnan. The high level of bronze casting in conformity with metropolitan Zhengzhou can only be associated with a center initially occupied by a substantial metropolitan population that mixed with locals yet continued to maintain loose contact with the capital at Erligang. ${ }^{76}$ The presence of two monumental tetrapod ding cast on-site strongly supports the hypothesis that this southeastern site was occupied by royalty, there to maintain economic and military control and thus dynastic power and cultural hegemony. ${ }^{77}$ Because precedent from capital sites strongly argues that monumental tetrapod ding belonged to royalty, Xin'gan may be viewed as a site representing the Shang royal house. It is highly likely that Xin'gan was governed by a royal son who had the prerogative to own and use large-scale tetrapod ding in royal cult sacrifices.

The presence of melting and casting specialists at the northern capital of Erligang demonstrates that metal resources were clearly understood and valued. When these large-scale ritual vessels appear on a similar scale at other regional sites, particularly Xin'gan and possibly Pinglu, their presence suggests the highest level of royal occupation. Another possible explanation is that Xin'gan was governed by powerful members of the Shang royal house who sought to advertise their power by competitively casting large-scale tetrapod bronze ding imitating capital style. Since the resources and knowledge to cast such large-scale Erligang-style tetrapod ding came from the capital and the uppermost crust of Shang society, and only the rulers could own monumental tetrapod ding, it is highly likely that Xin'gan, Jiangxi, Pinglu, and Shanxi were powerful regional states in their own right, governed by royalty as fangguo or $y i$ (settlements).

\section{CONCLUSION}

Monumental tetrapod ding vessels represent some of the largest cast ritual vessels known from ancient China. The social stratification of the ruling class as to who may use what type of ding strongly corroborates that possession and use of these monumental vessels were the prerogative of kings and royal sons in line of succession to the throne. Oracle bone inscriptions referring to yiding, "spirit-empowered ding," also strongly support the theory that such vessels were royal property. Finally, the presence of monumental tetrapod ding vessels at distant towns such as Xin'gan suggests not only the presence of Shang royal house family members, especially princes, at distant regional states and city sites, but also suggests that these important centers were under the hegemonic authority of Shang rulers and were pivotal in advertising royal Shang power and divinity (Childs-Johnson 2013b). In short, monumental tetrapod ding were the preeminent symbol of royal and divine power during the Shang period. 


\section{ACKNOWLEDGMENTS}

I want to express heartfelt thanks to the two anonymous readers of this manuscript, as well as to colleagues who generously gave their time to read over the manuscript at every stage of its evolution. I thank Li Feng, Connie Cook, Robert Murowchick, and especially John Major. I am also deeply grateful to the careful reading by the editorial staff of Asian Perspectives, including the Editor, Laura Junker, and Managing Editor, Jaida Samudra.

\section{NOTES}

1. The translation is based on Wu (1989:92-93) with two corrections. Ding 鼎 is usually translated “ding not as tripod," a misnomer long repeated in scholarly texts. Ding vessels are not restricted to tripods. It is the traditional name for both tripod and tetrapod versions of the vessel type. Wang is translated "king," not as "emperor."

2. There is one exception according to Liu (1991) and Yang (2002). A Western Zhou vessel collected in Jiajiacun, Qishan is inscribed “Shiyi zuo fangding 史亦作宝方鼎 [Shiyi made the precious fangding]." No Shang version or other Western Zhou example known to this author is inscribed with that name. Tetrapod and tripod ding were more commonly inscribed with terms such as “旅鼎 traveling ding,"

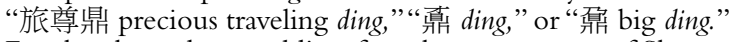

3. For the chronology and list of posthumous names of Shang queens and kings used here, see Itô and Takashima (1996: table 1 frontispiece). For other lists of kings, see Keightley (2000:132-133) and Chang (1980:6).

4. The Shang kingdom is frequently called “DaYi Shang 大邑商” or “Zhong Shang 中商” in late Shang bone inscriptions (Song $2005: 25-28$ ) and Western Zhou bronze inscriptions such as on the He zun 何尊 (Shaanxi 1976, 1:60-66). "Shang" refers to both the kingdom and its peoples.

5. David Pankenier identifies specific dates for the beginning (1576 в.С.Е.) and end (1046 в.С.в.) of Shang based on archaeoastronomical data. He discusses what he identifies as "planetary massings" that determined the beginning of China's first historic dynasties: Xia, Shang, and Zhou (Pankenier $1995: 124,132)$. He dates the Zhou conquest of Shang to 1045 B.C.E. and thus the end of Shang to 1046 B.C.E. See Pankenier (1981-1982:23, table 1) for an earlier reconstruction of the Shang through Zhou chronology. David Nivison $(1999,2009)$ maintains that the Zhou conquest took place in 1045 B.C.E. Other recent studies include Tang Jigen's (1999) identification of Middle Shang and the Xia Shang Zhou chronology project (Xia 2000).

6. A recent site report features three cache finds with large-scale tetrapod ding at Zhengzhou (Henan 1999). Although the authors of this report suggest big ding belonged to royalty and may have been used to serve them (Henan 1999:101), they are primarily concerned with dating the vessels. They demonstrate that the three pits, within which the bronzes were buried, preexisted and were reused during Erligang Period III, making the cache burials transitional in date between Period III and the rebuilding during the last period of occupation, Period IV. The date for filling the pits with bronzes, however, does not correspond to the date the bronzes were cast.

7. Akatsuka Kiyoshi's (1977) study is still the most thorough attempt to put together what constitutes Shang as opposed to Shang-Zhou vessel inscriptions. For a review of 66 out of 211 clan names in Shang bone inscriptions, see Ding Shan (1956). Also see Ma (n.d.:1-13).

8. Oracle bone inscriptions have been collected into lengthy compendiums that are normally cited by a short version of the title of the compendium rather than by the name of the compiler. Most of the inscriptions listed in this article are quoted from the Heji (1978-1982, 1999a, 1999b) compendiums compiled by Guo Moruo and follow his numbering system. The Qian (1913) compendium compiled by Luo Zhenyu follows a different numbering system.

9. Many tripod and tetrapod ding also carry soot on their underbellies and legs and animal bones in their bellies. Examples include the large-scale tripod ding no. 808 and the Hou Mu Xin tetrapod ding from M5, Xiaotun (Kaogusuo 1980:34-38), four large-scale tetrapod ding from the three Erligang cache pits (Henan 1999:10,17), and various small tetrapod ding with chicken bones and lower belly soot from Chang Zi Kou's tomb at Luyi, Henan (Henan 2000:68, 71). In 1982, an early Western Zhou tripod from a site in Luoyang in the Luoyang Provincial Museum was exhibited with the remains of pig bones. For other remains of animal bones or of soot on bottoms of other ding, see Hayashi (1964:201ff), Guo (1981:40, 161), Li (1970: pl. III [R2054], pl. IV [R2049], pl. XVII [R1752, Anyang ding]), and Yang Baocheng (2002:163). For the remains of different animal bones filling ding from the royal burial at Leigudun, see Hubei (1989:189-201).

10. Most excavated Erlitou ritual bronzes average between 12 and $20 \mathrm{~cm}$ tall and date to Periods III-IV (Kaogusuo 2008:134-137, 151-158, fig. 14). The tallest are two jia measuring 30.5 and $26.8 \mathrm{~cm}$ high (Zhongguo 1996: pls. 13-14). In contrast with Erligang period bronzes, it is noteworthy that 
none of Erlitou date are decorated with what was to become the hallmark of Shang ritual bronze imagery: the animal mask. Other bronze artifacts of Erlitou date include zhang 璋 insignia, ge 戈 daggers, dao 刀 knife blades, yue 钱 axes, arrow-points, a few tool types (Du and Xu 2005:775, fig. 1; 714, fig. $2: 3$; 665, fig. 9:8; 656, fig. 7:1; 633, fig. 2:1-3) and small bells and small turquoise inlaid plaques (Zhongguo 1996: pls. 20-24). No large-scale royal Erlitou tomb has yet been discovered. Note that many Erlitou metal samples are pure copper; leaded bronze only appears during the last phase of Erlitou Period IV (Jin et al. 1999).

11. Geoarchaeological analyses of Erlitou bronze or copper composition and location of mine sources are more complex than Liu and Chen's (2003) survey suggests. Erlitou likely had more than one source of lead for production of leaded bronzes, including Shandong in the northeast (Jin 2000:51-64, 69; Jin et al. 1999:202-203).

12. As pointed out by Chen and co-workers, most of China's sulfide mineral deposits and other metallic mineral deposits containing galena were formed during the Mesozoic and a minority during later Palaeozoic, Cenozoic, and pre-Cambrian periods. They are mainly distributed in the middle and lower Yangzi valleys and Yunnan-Guizhou plateau. The chemical composition of these deposits does not change, so these deposits provide a standard for measuring lead radioisotopes (Chen et al. 1980: 215-217; Jin 2002; Peng et al. 2000). In 2002, Chinese geologists and geochemists discovered at Ludian a large-scale native copper mine and nearby lead-zinc mines at Yongshan and Lemachang in northeast Yunnan with high radiogenic lead (Jin 2002). The only other concentrations of this special and rare high radiogenic lead are in the Mississippi river delta and near large-scale native copper mines of Keweenaw in Michigan.

13. Use of this archaeometallurgic technique is prominent in the work of researchers in China, Japan, and the United States (Chase 1996-1997; Jin 2000:169-174; 2008:27-29; Jin et al. 1998a, 1998b; Mabuchi and Hirao 1987; Peng et al. 2000; Young et al. 2010:1034-1039; Zhu and Chang 2002). $\mathrm{Pb}$ (lead) isotopes are of interest to the study of ancient bronzes because they provide insight into the geological history of the ore and its mode of formation (Ilonnikov 1975; Jin 1990; Jin et al. 1998a; Mabuchi and Hirao 1987). Peng et al. (2000) examined the geographical origin of $\mathrm{Pb}$ isotopes in China and divided the Chinese ore sources into three areas by $\mathrm{Pb}$ isotope ratios: high radiogenic lead $(208 \mathrm{~Pb} / 206 \mathrm{~Pb}$ less than 2$)$, middle ratios $(208 \mathrm{~Pb} / 206 \mathrm{~Pb}$ from 2 to 2.16$)$, and northeastern sources $(208 \mathrm{~Pb} / 206 \mathrm{~Pb}$ greater than 2.16$)$. High-radiogenic lead originated from polymetallic ore deposits formed from uranium in southwestern China (Young et al. 2010:1034). As Chase (1996-1997:499) points out, "The guiding principle behind the work is that lead used in a particular historic object has a particular set of lead isotopic ratios. ... The ratios should tell us the source of the lead, as the different ore deposits worldwide each have different characteristic ratios."

14. For colorplates of these southern bronzes of early to middle Shang date, see Zhongguo 1996: pls. 79 (Feixi, Anhui), 80 and 147 (Liuan, Anhui), 115 and 116 (Yueerhe, Anhui), 118 (Zhuzhai, Anhui); Gao 1997: pl. 43 (Dachang, Chongqing [formerly Sichuan, now Three Gorges]); Gao 1990: pl. 44 (Yueyang, Hunan); Sichuan 1999:239-281 (Sanxingdui). For analyses of some of these bronzes, see Kane (1974), Li (1998:243-293), Rawson (1994), and Allan (1998).

15. According to archaeometallurgist Jin Zhengyao, Tongling in Anhui was also mined during the Erligang period (personal communication, January 20, 2010).

16. Erligang people exploited the copper-mining sites of Tongling in Ruichang, Jiangxi (Lu and Liu 1993) and Tonglushan in Daye, Hubei (Huangshi 1999; Xia and Yin 1982). Lu Benshan (2006) states that the mines in Jiangxi and Hubei began to be exploited as early as the late Longshan period, as represented by remains at Pingliangtai in Henan. Lu and Liu (1993) maintain that mining or extracting copper at Tongling in Jiangxi began as early as the Xia (also see Liu and Chen 1998:116, 152n2). Copper smelting (not casting sites of Erligang date) has also been identified at Mianyangdi, Gutandun, and Lihe in Daye, all near the copper mine at Daye (Huangshi 1984; Liu and Chen 1998:116). There is also abundant evidence for earlier Erlitou period influence in these southern areas, particularly in finds from the far southwestern site of Sanxingdui, Sichuan (Childs-Johnson 1995: 82-85 and Du 2007b : 188-196, 197-198) and at Panlongcheng in Hubei, which was settled as early as the late Erlitou PIII-IV periods (Hubei 2001, 1:10-13). Early Shang bronze types from Sanxingdui, particularly zun 尊, simulate Erligang period types.

17. For examples, see Kaogusuo (1995:31, pls. 1, 3, 56, 73, 103, 116, 127, 149, 158, 179, 230, 246, 263-264, 291, 318, 348, 354-355, 383, 394, 412).

18. The use of specialized wares to honor the deceased may be qualified as the beginning of ancestor worship. Specialized wares such as he, gui, and $h u$ pitchers, blackware ding, other blackwares, and hard-fired white wares appear earliest in the Longshan and Liangzhu period burials (c. 3000-2000 B.C.E.). For examples of Longshan blackwares, see Underhill (2002:127, 150, figs. 5.32 and 6.2); for Liangzhu blackwares, see Huang (2000: pls. 136-139).

19. Liu and Chen $(2003: 147)$ point out that “[our] study supports [Kwang-chih] Chang's argument that production of bronze ritual objects and weapons for power acquisition was one of the major components of urbanism in early China (Chang 1985). However, our research disagrees with the proposi- 
tion that the frequent relocations of the capital cities of the Three Dynasties were directed at chasing after new sources of metal. It was population expansion and the establishment of outposts or fortified towns in the periphery by the political centres in the core . . that were the strategies for acquisition of key resources. These strategies were practiced as early as the Erlitou period, and continued until the end of the Erligang phase."

20. The taller one is mislabeled fangding in Kaogusuo (1965:219, fig. $7: 10)$.

21. Many scholars have discussed Di, usually translated "God," and Tian, variously translated "Heaven" or "Sky" (Allan 2007; Eno 1990, 2009:70-77). I identify Di as both a primordial and cosmological power (Childs-Johnson 2008:30-39, 44-45nn4-6).

22. Chen Mengjia, the earliest scholar to identify the Shang king as a spirit intermediary based on bone inscriptions, used the term chun wu zhi zhang 群巫之长, chief in charge of shamans (1937:531, 535-538; Childs-Johnson 1995:82-88). As Chen pointed out, the Shang king personally divined and prognosticated, as well as presided over all rites of divination and worship. K. C. Chang followed his interpretations although he did not himself analyze bone inscriptions (1980:45-47, 75). Shirakawa agrees that the king was supreme diviner as well as supreme exorcist $(1977: 15-26)$. For different views see Eno who describes the Shang king as a "thearch" and Keightley who describes the Shang king as a bureaucrat type of king without shamanic powers (Eno 2009: 85, 93; Keightley 2000:98-103).

23. As a verb of communication, bin in bone inscriptions has long been misunderstood as equivalent with the modern graph, "to entertain or to receive [a guest]" (see Childs-Johnson 2008:51-57).

24. The Shang concept of themselves as the center of the realm extending out in four directions and quarters has been discussed and analyzed by many scholars (Allan 1991:74-111; Chang 1970:230-233; Chen 1956:319-320; Childs-Johnson 2013; Hu 1972, 1:369-390; Shima 1975:229-233; Shirakawa 1977:41-47; Song 2005, 1:25-42, 57-90; Wang 2000:23-74; Wheatley 1971). For sifang or situ (quadrant lands) cosmology in Shang times, see Song (1991:200); Ye (1990); and Song (2005:34-42, 70). Song Zhenhao (2005:40-41) discusses other quadrant orientations, including “sizhi 四至” or geographical outer limits of the sifang and “sige 四戈” or administrative guardians in charge of territorial expansion of the Shang kingdom.

25. The Shang king's powers may also be described as extending above and below shangxia 上下, in signifying Di and royal ancestor spirits (Shirakawa 1977:53). Also see relevant bone inscription citations and identifications by Chen Mengjia and Hu Houxuan discussed in Shima (1975:194-195).

26. Remains may be classified as belonging to a capital and city-center site for many reasons. Site remains are large in scale and layout, include massive architectural structures, are surrounded by a pair of city walls and burial grounds, and are replete with their own workshops producing bronzes, jades, and ceramics (An 1999: 136-250; Henan 2003).

27. Other monumental examples derive from two regional sites or centers: Qianzhuang 前 just northwest of Erligang in Pinglu, Shanxi and distant Dayangzhou in Xin'gan, Jiangxi province.

28. All the pits were filled with dirt containing ceramic potsherds identifiable as Period III in date, indicating that the pits were dug or reused when the site was partially destroyed through burning, probably as a result of warfare followed by reconstruction, at the transition between Periods III and IV, and not when the site was abandoned at the end of Period IV (Du and Xu 2005).

29. For discussion of the early predilection for dualistic representation in Shang culture, see Chang (1964, 1980:171-189) and Wu (1995:34-35).

30. Cinnabar (toxic mercuric sulphide) was commonly used to cover tombs, burial goods, and corpses in the late Neolithic and the Bronze Age of China. For cinnabar's probable association with the color of blood and life in the afterlife, see Needham, Ho, and Lu (1976:3).

31. No bronzes from royal-sized tombs that could be used for typological and stylistic comparisons have yet been excavated at Erligang. The excavators date the cache bronzes to primarily two phases, Erligang Upper Level early and late phases (Henan 1999:99). Based on bronze types and style, there is clearly an evolution that differentiates in date these bronzes from the three caches. For example, the two thin-wall and light-in-weight tetrapod ding from H1 at South Shuncheng Street (H1:3-4) clearly predate the much-thicker-wall and heavier version of tetrapod ding from the same pit $(\mathrm{H} 1: 1)$. The two, H1:3-4, are clearly experimental and representative of the earliest examples of the type cast. Based on a limited number of excavated bronzes from the Zhengzhou site it is not yet possible to date these tetrapods to Erligang Lower Level or Upper Level. Bronze vessel types other than the tetrapod ding found in the Erligang caches are comparable to Erligang Lower Level types known from other burials at Erligang (e.g., Henan 2001, 1:567, C8M7 with bronze jue, jia, and ge; 2: pl. 9). The cache bronzes appear to date to a broader time frame covering Erligang Lower Level and Upper Level periods.

32. Measurements of representative medium-sized ding are from tomb M5 of Fu Zi, two dragon leg tetrapod ding measure (in centimeters) $42.4 \times 33.3-25.1 \times 0.5$ thick, $17 \mathrm{~kg}$, and $42.3 \times 34.1-$ $24.8 \times 0.5 \mathrm{~cm}$ thick, $18 \mathrm{~kg}$ (Kaogusuo 1980); from the tomb of Chang Zi Kou two (mingqi) tetrapod ding measure $27.6 \times 21.2-16.4 \times 0.25$ thick, $47.2 \mathrm{~kg}$, and $27.8 \times 22-16.8 \times 0.25$ thick, $44.5 \mathrm{~kg}$, 
along with two $\mathrm{Xi} \mathrm{Zi}$ Sun tetrapod ding measuring $21.4 \times 16.8-14 \times 0.3$ thick, $30 \mathrm{~kg}$, and $21.6 \times 16.8-3.9 \times 0.35$ thick, $30 \mathrm{~kg}$ (Kaogusuo Anyang Gongzuodui 2004).

33. Measurements of representative small tetrapod ding come from only one early-middle Shang tomb at Pingguxian, Hebei, measuring $14.2 \times 11 \times 8.7$ (Zhongguo, 1: no. 45); two from tomb M5 of Fu Zi measuring $12.2 \times 9.2-7.6,0.7 \mathrm{~kg}$ (Kaogusuo 1980); two from the tomb of Ya Chi M160 measuring $21.6 \times 16.6-13.5 \times 0.65,3.85 \mathrm{~kg}$, and $18.5 \times 12.8-11 \times 0.4,1.6 \mathrm{~kg}$ (Kaogusuo 1998: 81); two from the tomb of Ya Chang M54 (nos. 170 and 191, scale based on personal examination and as provided in Kaogusuo Anyang Gongzuodui 2004:9, fig. 3); five lidded examples from the tomb of Chang Zi Kou, measuring $19.4 \times 14-10.5 \times 0.3$ thick, $17 \mathrm{~kg}$, and $19.5 \times 14.1-10.4 \times 0.3,18 \mathrm{~kg}, 19.8 \times 14.4 \times$ $10.6 \times 0.3,17.5 \mathrm{~kg}, 19.7 \times 14-10.4 \times 0.3,17 \mathrm{~kg}$, and $19.2 \times 14.2-10.6 \times 0.3,17.5 \mathrm{~kg}$ (Kaogusuo Anyang Gongzuodui 2004).

34. One vessel, a yan steamer, measures $105 \mathrm{~cm}$ tall, an exceptionally tall example (Zhongguo 1996:10, pl. 30), slightly larger than the largest monumental tetrapod ding at $97 \mathrm{~cm}$ at Xin'gan. This is the exception and Xin'gan is an exceptional site. The tallest tetrapod ding remains the example unearthed from M260 at Xibeigang, measuring $133 \mathrm{~cm}$ tall (Table 1).

35. There is still debate about whether the remains at Zhengzhou may be associated with the first or second Shang capital, traditionally called Bo and Ao (Xiao), respectively, in later literature. The late archaeologist in charge of excavations at Zhengzhou, An Jinhuai, adhered to his theory that Zhengzhou was the second capital of Shang (see, e.g., An 1986:15; Chang 1980:263-273; and Henan and Zhengzhoushi 2001, 1:5-6).

36. As reported by Wei Si (1992), although damaged on its southern and eastern sides, the site occupies a raised mound area of about $10,000 \mathrm{sq} \mathrm{m}$, an area that approximates that of the middle Shang site of Taixi in Gaocheng, Hebei $(1985: 2,209)$. At the time of road repair 3000 square miles were destroyed.

37. Very few intact royal burials of early, middle, or late Shang date have been identified at capital sites with the exception of $\mathrm{Fu} \mathrm{Zi}$ 's tomb at the late Shang capital of Anyang (Childs-Johnson 1983, 2007: 19-25; Kaogusuo 1980).

38. Wu Hung (1995) makes an excellent case for monumentality and monuments in early China. Although he does not address Shang tetrapods or Shang evidence for monumentality in terms of physical or artistic remains he reviews what he maintains represents monumentality of the Bronze Age: the legend of the Nine Tripods that symbolized political authority and power in the historical tradition. Wu (1995:10) writes, "The story of the Nine Tripods is probably sheer legend: . . no one ever claimed to have seen them. . . But to me, their value as historical evidence lies not in their physical form, not even in their existence, but in the myth surrounding them."

39. No royal-sized tombs have been excavated from the middle Shang site of Huanbei Shangcheng at Anyang or the newly discovered early to middle Shang site, Daxinzhuang, in Shandong.

40. Queen Fu Zi is also known as Noble Lady Zi or Honorable Queen Mother Xin 后母辛. Fu refers to a female born of or married to royalty or members of the ruling house (Zhu Fenghan 1990:123). "Royal Son" for the $z i$ 子 character is classificatory in referring to a male born of royalty (Zhu 1990:39-67). Past translations of $z i$ include "child" but reference is clearly to a male child, thus son, and because the sons are those associated with the offspring of the Shang king and his brothers, they are royal sons when referenced in Shang bone inscriptions. For an in-depth study of Fu Zi, see Cao (1993) and Childs-Johnson (2003, 2007:19-25) for citations of other relevant studies. Fu $\mathrm{Zi}$ is also popularly known as $\mathrm{Fu} \mathrm{Hao}$, but as several scholars have pointed out $\mathrm{Zi}$ rather than $\mathrm{Hao}$ is a more accurate transcription due to the fact the female radical 女 is inconsistently included flanking the surnames of Fu 婦, as represented by $\mathrm{Fu} \mathrm{Zi}$ 婦子, which is sometimes written 女 + 子 or simply 子, or by Jing 井, which is sometimes written by combining 女 + 井 or simply 井 for the name of Wife Jing or Fu Jing 婦井. The addition of the female radical 女 to surnames of $f u$ in Shang bone inscriptions functions for emphatic and aesthetic purposes, or for simple clarification that the surname refers to a female (Chang 1986:103-104; Chang 1997:129-130; Childs-Johnson 2003, 2007; Zhang 1985 : 1119).

41. There are still many unresolved questions concerning the identification of queen and king burials. None have been clearly identified except for the M5 and M260 queen burials.

42. "Gifts" are commonly represented as offerings in elite Shang burials. Fu Zi was honored by many gifts, including five jade ge daggers sent in from the Lufang in addition to many others with named tributaries (Childs-Johnson 2003:630-634; Kaogusuo 1980:131-136).

43. Posthumous day-names were identical to the name of the day, selected from the ten-day week, on which a royal individual would receive sacrifices in the ancestral cult.

44. Fu Ji's premature death during Wu Ding's reign is corroborated by abundant bone inscriptional data. Fu Ji, for example, was known as "Xiao Wang 小王 (Small King = Heir apparent)" in Wu Ding period inscriptions; as Brother Ji 兄己 during Fu Geng and Fu Jia Period II bone inscriptions; and as Fu Ji 父己 or as Xiao Wang Fu Ji 小王父已 in Period III bone inscriptions, demonstrating he was the object of royal sacrifices. Both Wang (1979:92) and Cao (2007:125-127) discuss why Fu Ji died soon after his mother, Fu Zi. Both Xiao Wang Ji and Fu Zi were objects of sacrifice in Wu Ding 
period inscriptions, which Wang (1979:92) and Cao (2007:121-122) date to the early to middle late Wu Ding period. Yang clarified why Fu Ji is the patron of the bone inscriptions discovered in 1991 from Huayuanzhuang East pit, H3, at Anyang, and why they date to Yinxu Period I or Dasikongcun Period I (Yang 2004:14-17, 208-209). Received texts refer to Fu Ji's premature death as taking place after his mother's yet early in Wu Ding's career, again underscoring that Fu Ji died as a xiaowang, or heir apparent. For other bone inscriptions documenting the Small King inscriptions see Childs-Johnson (2003: 623-626). Cao (2007:117-122) maintains that Fu Ji is identified by another name, Wang P王 $\mathrm{P}$, as documented by corroborative inscriptions (for further discussion see text pages 190-192).

45. For plundering of the royal tombs see Li Chi (1977:88). As Soper pointed out, "All historical use of the finds from the royal tombs is handicapped by uncertainties of dating. . . One can perhaps assign a likely date to 1001 by a line of reasoning applicable only to it and its immediate neighbors . . this [physical] situation points to two adjacent generations in a royal family, a father and his three sons" (1966:26). Also see Shirakawa (1977:26-30); Song (2005:835-839); and Yang (1981, 1983).

46. For other queens referred to posthumously by the title Hou see Yao and Xiao (1989:846-847). 1-2. Hou 后 (also transcribed si 司) is distinguished from the bone graph 毓 $(\gamma u)$, often conflated and confused in its reading as hou, descendant (see Hsü 1972:29; Qiu 1985). In Shang bone inscriptions the word for descendant is written differently from the graph for hou; $y u$ is composed of two graphic elements, that for female and for child, of which the latter is written upside down and to the right and rear of the female element (Song 2005:225, 289).

47. I use heir apparent in its traditional meaning: as a person who is first in line of succession and cannot be displaced from inheriting, except by a change in the rules of succession.

48. The so-called "Zi group" divinations identify $z i$ 子, royal sons who were heirs apparent to the throne in at least one clear case. For the identification of one of these $z i$, Fu Ji, see Yang (2004). As "royal sons," not ruling kings, none of the $z i$ 子 engaged in cult ceremonies associated with royal prerogative such as the power to bin 宾. For a review of Zi group divinations discovered in pit $\mathrm{H} 3$ at Xiaotun, see Smith (2008); for other Zi group divinations, see Song and Liu (2006:181-207).

49. For other examples of inscriptions referencing $P$ seeYao and Xiao (1989: 196:3-4) and Heji: 115:3-4.

50. The name for Small King Ji in later received histories such as the Lüshi Chunqiu (third century B.C.E.) is Xiao Ji, not the xiao 小 for small but the xiao 孝 for filial (Chen 1956:430-431). As noted by Huang (1989:31), in the Jinben Zhushu Jinian (before third century B.C.E.) it is recorded that in Wu Ding's 25th year, Royal Son Xiao Ji died in the wild.

51. For a brief account of M260, unearthed in 1984, see Guojia (2001:24, chart, map no. 4, and layout drawing no. 11; note that no. 11 is confused with the other large tomb, no. 12, discovered in 1950 at Wuguancun - the no. 11 burial should read M260 and no. 12 burial should read 50WGKM1).

52. Other royal sons of Fu Ji's generation, including successive kings, Fu Geng and Fu Jia, although when they assumed the throne as kings they could also engage in sacrifice to $\mathrm{Mu} \mathrm{Xin,} \mathrm{it} \mathrm{would} \mathrm{not} \mathrm{have}$ been possible for either of them to deposit the tetrapods in her tomb because, as noted above, they had not yet assumed the position of heir apparent or king.

53. Other theories concerning the large-scale burials at Xibeigang associate M260 with Wu Yi's queen (Kane 1976:105-106). Here it is maintained that Hou Mu Wu refers to Zu Jia's mother (King Wu Ding's third wife) rather than King Wu Yi's wife. This identification follows Alexander Soper's theory about the occupants of the royal late Shang cemetery at Xibeigang, Anyang. According to his theory, the almost totally looted, central large burial M1001 in Xibeigang West was that of the powerful king Wu Ding; the three others surrounding M1001 (i.e., M1004, M1002, M1550) are identified with his three sons, Zu Ji, Zu Geng, and Zu Jia (Soper 1966:26). In theory, the other five burials at Xibegang belong to the remaining five late Shang kings who succeeded Wu Ding and his three sons. The incomplete burial M1567 at Xibeigang West is probably that of the last king, Di Xin, who died with the Zhou conquest and was not able to see through the construction of his tomb. For other theories see Yang (1983:930).

54. It should be pointed out that both tetrapod ding inscribed "Honorable Queen Mother" appear in non-cruciform-shaped burials, suggesting that the two queen burials may have more in common than is currently known from excavated data.

55. A binome, or hewen 合文, is a combination of two graphs into one.

56. Wu Hung uses the term "metamorphic" to describe the artistic style of representation on Shang bronzes (1995:50-52), yet not in the religious sense of $y i$ as used in bone inscriptions. Metamorphism is the foundation of Shang belief as is maintained through analysis of paleographic data and standards of representation in art (Childs-Johnson 1995, 2008).

57. They are comparable to the set of five small-scale identical tetrapod ding fashioned by the Shang noble, Chang Zi Kou (Fig. 14 and Table 3).

58. For example, Kern (2007:120) mentions that "Secretaries" and "Makers of Records" during the early Western Zhou were of Shang descent recruited by the Zhou. "Scribe of the Bird on the Perch clan" is also listed by Shirakawa as one of the major "emblems [clan signs]" in Shang bronze inscriptions (cited in Chang 1980:164, fig. 43). 
59. Authors differ about precisely when the so-called systemizing of numbers of ding and other ritual vessel types actually began to be significant in the Western Zhou tradition. Yu and Gao (1978) identify the trend as beginning probably in the early and middle phases of the Western Zhou whereas Falkenhausen (2006:49-52) would trace the beginning much later, during the late Western Zhou period. Because numbers of types of ritual vessels were significant since the Shang period, the tradition of identifying vessel types as sets or pairs continues with stylistic changes yet not as a revolutionary movement with radical change, as once suggested by Rawson (1990:96-98).

60. Numbers of excavated ding do not always adhere to the ideal numbers formalized in the ding zhifa. This may be due to political choice at the time they were made or different conditions of preservation in the archaeological record.

61. Many ding, gui, and other vessel types forming sets found in Western through Eastern Zhou burials typically have identical imagery and shapes but are commonly distinguished by a pair of two largescale ding, one of which is usually larger than the other. For example, the Da Yu 大孟 (Large Yu) ding inscription, dated to the Western Zhou king Kang, records that its owner (Yu) cast a large ding and a smaller one. The Da Yu is now preserved in the National Museum of China, Beijing. The inscription of the smaller one, known as the Xiao Yu 小孟 (SmallYu) ding, has been preserved, but not the vessel itself (Yu 1995: 89).

62. Pairing of royal-sized large-scale tripod ding is also represented at other Eastern Zhou elite burials, such as the Marquis Cai 蔡侯 tomb at Shouxian 寿县, Anhui. Those from one Shouxian tomb comprised one large-scale example $(55.3 \mathrm{~cm}$ tall $\times 62 \mathrm{~cm}$ mouth diameter), a set of seven ding, and another set of ten ding (Anhui 1956:6-7).

63. One of the more celebrated large-scale tripod ding is the $48 \mathrm{~cm}$ tall example dating to the late Shang period that was unearthed from a sacrificial pit at Hougang, Anyang in 1959 (Zhongguo, 2:14, pl. 28).

64. These routes were already well established by the late Xia and early Shang periods, as is evident from the distribution of late Longshan/Xia and early Shang finds throughout the Yangzi River valley.

65. Song and Liu (2006:254-276), Yang (1992), Song (2005), and Cao (2007:26-43) have studied extensively the evidence in bone inscriptions for royal lands and regionally owned lands of late Shang date. Many of these lands are identified as settlements (cities), yi 邑. It is well known that $\mathrm{Fu} \mathrm{Zi,} \mathrm{Wu}$ Ding's first queen, Hou Mu Xin, owned lands identified as $\mathrm{Zi}$ 子 or Zi $y i$ 子邑 northwest of Anyang (Song 2005; Yang 1992:65). The fangguo 方国 or quadrant regions surrounding the royal Shang capital, Shang da $y i$ 商大邑, are identified as fangguo $y i$ 方国邑. Pinglu is undoubtedly one of these $y i$ centers as were Xin'gan and Panlongcheng.

66. See Cao's (2007) discussion ofYa Qi, Zi Qi, Lufang, and Hei Bo.

67. It has not yet been possible to identify any specific early Shang king.

68. A large tripod ding discovered in one of the Panlongcheng burials measures $55 \mathrm{~cm}$ tall (Zhongguo, $1: 32)$. It is typologically comparable to the larger $77.3 \mathrm{~cm}$ tall example excavated from pit $\mathrm{H} 1$ at Xiangyang Moslem Grocery at Zhengzhou (Henan 1999:87, fig. 62:3).

69. Panlongcheng was located on a tributary of the Yangzi. It was defended by a fortification wall and had a complex scaffolding for a large dock (Hubei 2001:4-5, maps figs. 3-4; also see 501-504).

70. The earliest dated monumental tetrapod ding are the two from South Shuncheng Street, Zhengzhou. Difficulties met in casting these two stand out in the awkward joining of legs to the bottom piece of the ding as well as in the joins of handles to rim (Li J. 1999: 106-110; Li and Guo 1999:113-119). In addition, the off-center irregular line of the nodule band of décor of the South Shuncheng Street $\mathrm{H} 1: 4$ tetrapod illustrates, by comparison to later examples with totally controlled and aligned bands, that these two were the result of experimental casts.

71. This use of bronze chaplet spacers also characterizes bronzes discovered elsewhere in South China, including early Shang (Erligang period) bronzes from Yueyahe 月牙河, Funan 阜南 in Anhui 安徽, and from Fangyushan 魴魚山, Qiuyang 岳陽 in Hunan 湖南 (Jiangxi et al. 1997:294-296).

72. Another eccentric form is the cruciform-shaped channel that pierces the belly of the bronze you XDM : 47; this was also designed to hold coals to heat the contents of the vessel (Jiangxi et al. $1997:$ 70, fig. 37).

73. These features are also characteristic of other southern early Shang bronzes from burial sites at Yueyahe and Fangyushan in Anhui and Hunan and farther afield down the Han and Huai Rivers in Qishan and Chenggu counties of Shaanxi province (Li 1994: pls. 38, 92, 100-101, 108, 128, 147, 189, 241-243, 247, 249, 251, 267-268, 253).

74. Other novel interpretations appear to be imports or works made by imported craftspersons from Erligang. These include, for example, a pou ritual vessel, XDM:30, identical in form to excavated middle Shang period types (see Bagley 1995:320-332, no. 53). Yet, the base is missing and three new legs added, in addition to two new handles cast onto the rim, creating in appearance a pou-style tripod ding (Jiangxi et al. 1997:49, 54-57, fig. 25). Similarly three legs and a new lid and handle have been added onto the you vessel XGM:48, which is otherwise completely standard in type and form 
(Jiangxi et al. 1997:69, pl. 18.1). Other bronze vessel types are completely standard in form and style with Erligang period vessels, suggesting that they were imports, gifts, vessels carried by metropolitan craftsmen, or vessels cast by metropolitan artisans. Representative examples include a gui serving vessel (XDM: 43), a $h u$ liquor container (XDM: 46), and a yan steamer (XDM: 39). The Xin'gan gui is particularly significant as a metropolitan vessel since it is inscribed with the emblem of a tortoise, visible on the inside of the foot (Jiangxi et al. 1997:61, fig. 33, pl. 85:3). Similar emblems are represented elsewhere on Shang bronzes (Bagley 1995:322, 336, figs. 53.2, 57.2, 103.3) and another was unearthed from M232 at Xiaotun, Anyang (Li and Wan 1972: pl. LIII.2b).

75. Wucheng and Xin'gan sites were settled during the early Shang rather than late Shang period, as mistaken by Li and Chen $(2003: 121)$.

76. This chronological scenario dating Xin'gan to the Erligang period also depends on the dating of certain Xin'gan bronzes that suggest non-Shang styles. These non-Shang types include weapons and one with a long haft extension (XDM:132 and 133; see Jiangxi et al. 1997:98, pl. 27:2, fig. 49:6). These types of weapons are unknown in early Shang metropolitan graves yet are well represented as far afield as Chenggu in Shaanxi province (see, e.g, Li 1994: nos. 241, 243, 246-247, 249, 251, 253), pointing to a southern Yangzi and Wei River valley connection of bronze casting that appears more advanced in weapon making than the Yellow River valley capital site at Erligang. It is maintained here that the settlement at Dayangzhou in Xin'gan, Jiangxi represents a major military outpost built and settled by royal house members to oversee control of trade routes, particularly associated with access to mine sites with bronze ores along the Yangtze River valley.

77. One unexplained difference between Xin'gan and Zhengzhou practices is the absence of gu, jue, jia, and he vessel types in the Xin'gan burial. These vessels are all associated with alcohol used for sacrifice and feasting.

\section{REFERENCES CITED}

AкAтsuka Kiyoshi 赤玩忠

1977 Chûgoku Kodai No Shû Kyô To Bunka- In Ôchô No Saishi 中國古代の 宗教と文花- 殷王朝の 祭祀. Tokyo: Kadokawa Publishing Company, Ltd.

Allan, Sarah

1991 The Shape of the Turtle: Myth, Art, and Cosmos in Early China. Albany: State University of New York Press.

1998 The tiger, the south, and Loehr Style III, in Proceedings of the International Conference: Chinese Archaeology Enters the Twentieth Century: 149-182. Beijing.

2007 On the identity of Shang Di 上帝 and the origin of the concept of a celestial mandate. Early China 31:1-46.

AN JinHUAI 安金槐

1986 The Shang city at Cheng-chou and related problems, in Studies of Shang Archaeology: 15-48, ed. K. C. Chang. New Haven and London: Yale University Press.

1999 An Jinhuai Kaogu Wenji 安金槐考故文集. Chongzhou Guji Publishers.

ANhui (ANhuisheng Wenwu GuAnli Weiyuanhui 安徽省文物管理委员会 AND ANHUisheng BowUGUAN 安徽省博物官)

1956 Shouxian Caihou Mu Chutu Yiwu 寿县蔡侯墓出土遗物. Beijing: Science Press.

BAgLEy, ROBERT

1995 Shang Ritual Bronzes in the Arthur M. Sackler Collections (Ancient Chinese Bronzes in the Arthur M. Sackler Collections, Vol. 1). New York: Arthur M. Sackler Museum.

Barnes, I. L., W. T. Chase, L. L. Holmes, E. C. Joel, J. P. Meyers, and E. V. Sayre

1988 The technical examination, lead isotope determination, and elemental analysis of some Shang and Zhou Dynasty bronze vessels, in Second International Conference on the Beginning of the Use of Metals and Alloys: 296-306. Cambridge, MA: MIT Press.

Beijing (Beijingshi Wenwu Yanjiusuo 北京市文物研究所 [Institute of Beijing Cultural Relics])

1995 Liulihe Xi Zhou Yanguo Mudi 琉璃河西周燕国墓地 1973-1977. Beijing: Cultural Relics Press.

CAO DINGYUn 曹定雲

2007 Yinxu Fu Hao Mu, Mingwen Yanjiu 殷噓婦好墓銘文研究. Kunming: Yunnan Peoples Press.

Chang, K. C.

1964 Some dualistic phenomena in Shang society. Journal of Asian Studies 24:45-61.

1980 Shang Civilization. New Haven: Yale University Press.

1983 Art, Myth, and Ritual, The Path to Political Authority in Ancient China. Cambridge, MA: Harvard University Press.

1986 The Archaeology of Ancient China. 4th ed. New Haven: Yale University Press. 
Chang, Tsung-T'ung

1970 Der Kult der Shang-Dynastie im Spiegel der Orakelinschriften: Eine Paläographische Studie zur Religion im Archaischen China. Wiesbaden: Otto Harrassowitz.

Chang Cheng-lang (Zhang Zhenglang)

1986 A brief discussion of Fu Tzu, in Studies of Shang Archaeology: 103-120, ed. K. C. Chang. New Haven: Yale University Press.

Chang PING-CH'ÜAN

1997 A brief description of the Fu Hao oracle bone inscriptions, in Studies of Shang Archaeology: 121-140, ed. K. C. Chang. New Haven: Yale University Press.

Chang Yuzhi 常玉芝

1987 Shangdai Zhouji Zhidu 商代周祭制度. Beijing: Science Press.

Chase, W. T.

1996- Lead isotope ratio analysis of Chinese bronzes: Examples from the Freer Gallery of Art and

1997 Arthur M. Sackler Collections, in The Ancient Chinese and Southeast Asian Bronze Cultures: The Proceedings of a Conference Held at the Edith and Joy London Foundation Property, Kioloa, NSW, 8-12 February 1988. Taipei: SMC Publishers.

Chen Banghuai 陈邦怀

1959 Jiaguwen Lingshi 甲古文甲骨文零拾: 附考釋. Tianjin: Tianjin Peoples Publishers.

Chen Mengjia 陈梦家

1937 Shangdai de shenhua yu wushu 商代神话与巫术. Yanjing Xuebao 燕京学报 20:466-576.

1956 Yinxu Buci Zongshu 殷墟卜辞综述. Beijing: Science Press.

Chen Yuwei 陈毓蔚, Mao Cunxiao 毛存孝, And Zhu BingQuan 朱炳泉

1980 Wo guo xian shengdai quanshu kuangshu qiantongweisu zucheng tezheng ji qi chengyin tantao 我国显生代全属矿术铅同位素组成特征及其成因探讨. Diqiu Huaxue (Geochemica) $3: 215-229$.

Childs-Johnson, Elizabeth

1983 Identification of the tomb occupant and periodization of M5, in Excavation of Tomb No. 5 at Yinxu, Anyang, Chinese Sociology and Anthropology XV:1-37. Armonk, NY: M. E. Sharpe.

1987 The jue-vessel and its ritual use in the ancestor cult of Shang China. Artibus Asiae 48 (3-4): 171-196.

1995 Symbolic jades of the Erlitou period: A Xia royal tradition. Archives of Asian Art 48:64-90.

1998 The metamorphic image: A predominant theme in Shang ritual art. Bulletin of the Museum of Far Eastern Antiquities 70:5-171.

2003 Fu Zi: The Shang woman warrior, in The Fourth International Conference on Chinese Paleography [ICCP] Proceedings: 623-666. Hong Kong: The Chinese University of Hong Kong.

2007 Fu Zi 婦子, the Shang woman warrior, in A Biographical Dictionary of Chinese Women, vol. 1: Shang through Sui Periods: 19-25, ed. Lily Xiao Hong Lee and A. D. Stefanowska. Armonk, NY, and London: M. E. Sharpe.

2008 The Meaning of the Graph "Yi" 異 and Its Implications for Shang Belief and Art. East Asia Journal, Monograph No. 1. London: Saffron Books.

2010 Shang and Western Zhou Jades. New York: Throckmorton Fine Art.

2013a Fu Zi, the Shang woman warrior revisited, in Festschrift in Honor of Professor Lily Xiao Hong Lee, University of Sydney, Australia, in press.

$2013 b$ "Postscript to Big Ding and China Power-Shang: Sifang Cosmology," in Proceedings of the International Conference for Commemorating 1 Century after Sun Zuoyun's Birthday: 191-210 (Jinian Sun Zuoyun jiaoshou bainian yanchang ji gudai Zhongguo lishi yu wenhua guoji xueshu yantaohui lunwenji 紀念孫作雲教授百年誕辰暨古代中國歷史與文化國際學術研討會 論文集)開封：河南大學, 2012 年11月11-13.

Childs-Johnson, Elizabeth, and Jin Zhengyao

2003 Early Shang bronze art and highly radiogenic lead, in National Gallery of Art, Center for Advanced Study in the Visual Arts, Center 23, Record of Activities and Research Reports, June 2002-May 2003, Washington, D.C.: 57-60.

Chou FA-Kao 周法高, Li Hsiao-TING 李孝, AND Cheung YAT-Shing 张日升, eds.

1977 Appendices to an Etymological Dictionary of Ancient Chinese Bronze Inscriptions 金文新林附录. Vols. 1-4. Hong Kong: The Chinese University of Hong Kong.

DING SHAN 丁山

1956 Jiaguwen Suojian Shizu Ji Qi Zhidu 甲骨文所見氏族及其制度. Beijing: Science Press.

DU JINPENG 杜金鹏

2003 Yanshi Shangcheng Yizhi Yanjiu 堰师商城遗址研究. Beijing: Science Press.

2007 Xia Shang Zhou Kaoguxue Yanjiu 夏商周考古学研究. Beijing: Science Press. 
DU JINPENG 杜金鹏 AND Xu HONG 许宏

2005 Erlitou Yizhi Yanjiu 二里头遗址研究. Beijing: Science Press.

ENO, ROBERT

1990 Was there a high god Ti in Shang religion? Early China 18:1-26.

2009 Shang state religion and the pantheon of the oracle texts, in Early Chinese Religion, vol. 1:41102, ed. John Lagerwey and Marc Kalinowski. Leiden and Boston: Brill.

Falkenhausen, Lothar von

2006 Chinese Society in the Age of Confucius (1000-250 BC): The Archaeological Evidence. Los Angeles: Cotsen Institute of Archaeology, UCLA.

GANSU (GANSUSHENg Bowuguan Wenwudui 甘苏省博物馆文物队)

1977 Gansu Lingtai Baicaopo Xi Zhou mu 甘苏灵台白草坡. Kaogu Xuebao 2:99-130.

GAO ZHIXI 高至喜, ED.

1990 Gems of China's Cultural Relics. Beijing: Cultural Relics Press.

1997 Gems of China's Cultural Relics. Beijing: Cultural Relics Press.

GetTens, Rutherford John

1970 The Freer Chinese Bronzes, Vol. 2: Technical Studies. Smithsonian Institution. Freer Gallery of Art. Oriental Studies, No. 7. Washington D.C.

GuO BAOJUN 郭宝均

1981 Shang Zhou Tongqi Qun Zonghe yanjiu 商周铜器群综合研究. Beijing: Cultural Relics Press.

Guojia Wenwuju, ED.

2001 Zhonghua Renmin Gongheguo Guojia Wenwuju ed. 中华人民共和国国家文物局 Yinxu 殷墟. Beijing: Cultural Relics Press.

Hayashi, Minao 林已奈夫

1964 In-Shû seidôki no meishô to yôto 殷周青铜の名称と用处. Tôhôgakuhô 34:199-297.

He, JiEgou 何介钩

1981 Hunan Shang Zhou shiqi gu wenhua de fenqu tansuo 湖南商周时期古文化的分区探索, in Proceedings of the Third Chinese Archaeology Symposium. Beijing: Cultural Relics Press.

HeBei (HeBeisheng WeNwu YanjIUSUO 河南省文物考古研究所)

1985 Gaocheng Taixi Shangdai Yizhi 营城台西商代遗址. Beijing: Cultural Relics Press.

HejI

1978- Jiaguwen Heji 甲骨文合集 (The Complete Set of Oracle Bone Inscriptions), vols. 1-13.

1982 Beijing: Science Press.

1999a Jiaguwen Heji: Shiwen 釋文, vols. 1-4, compiled by Guo Moruo 郭漠若. Beijing: Science Press.

1999 Jiaguwen Heji: Cailiao Laiyuan Biao 材料來源表, vols. 1-2, compiled by Guo Moruo 郭漠 若. Beijing: Science Press.

Henan (Henansheng Wenwu Kaogu Yanjiusuo 河南省文物考古研究所)

1996 Sanmenxia Shi wen wu gong zuo dui (Cultural Relics Archaeological Team of Sanmenxia). Sanmenxia Guoguo Mu 三门峡虢国墓. Beijing: Cultural Relics Press.

1999 Zhengzhou Shangdai Tongqi Jiaozang 鄭州商代銅器窝藏. Beijing: Science Press.

2001 Zhengzhou Shangcheng 鄭州商城商, vols. 1-3. Beijing: Cultural Relics Press.

2003 Zhengzhou Wenwu Kaogu Yanjiu 鄭州文物考古研究, vols. 1-2. Beijing: Cultural Relics Press.

Henan, Henan, and Xichuanxian (Henansheng Wenwu Kaogu Yanjiusuo 河南省文物考古研究 所, Henansheng Danjiang Kuqu KaOgu Fajue Dui 河南省丹江库区考古发掘队, AND XICHUANXIAN BOWUGUAN 淅川县博物馆)

1991 Xichuan Xiasi Chunqiu Chumu 淅川下寺楚墓. Beijing: Cultural Relics Press.

Henan and Zhengzhoushi (Henansheng Wenwu Kaogu Yanjiusuo 河南省文物考古研究所 AND ZhengZhoushi Wenwu KaOgu Yanjiusuo 鄭州市文物考古研究所)

2001 Zhengzhou Shangdai Tongqi Jiaozang 鄭州商代銅器窝藏. Beijing: Science Press.

Henan and Zhoukoushi (Henansheng Wenwu Kaogu Yanjiusuo 河南省文物考古研究所 AND Zhoukoushi Wenhuaju 周 $\square$ 市文化局)

2000 Luyi Taiqinggong Changzikou Mu 鹿邑太清宮長子 $\square$ 墓. Zhengzhou: Zhongzhou Guji Press.

Hsü CHIN-HSIUNG 许近雄

1968 Yin-hs'u Pu-tz'u Chung Wu-chung Chi-ssu-de yen-chiu 殷噓卜辞中五种祭祀的研究. History and Chinese Literary Series No. 26. Taipei: Taiwan University.

1972 The Menzies Collection of Shang Dynasty Oracle Bones, vols. 1-2. Toronto: The Royal Ontario Museum. 
Hu Houxuan 胡厚宣

[1945] Jiaguxue Shangshi Luncong 甲骨学赏史论从, vols. 1-3. Taipei: Taiwan Ta-t'ung Shu-chu You1972 hsien Kung-tse.

HuAng Tianshu 黄天

1989 Zi Zu Buci Yanjiu 子族卜辞研究. Zhongguo Wenzi 26:11-31.

HuANG XuANPEI 黄宣佩, ED.

2000 Fuquanshan 福泉山. Beijing: Cultural Relics Press.

HuAngshi Bowuguan 黄市博物官

1999 Tonglushan gukuangye yizhi 铜绿山古矿冶遗址. Beijing: Cultural Relics Press.

Hubei Bowuguan 湖北博物馆

1989 Zeng Hou Yi mu 曾侯乙墓, vols. 1-2. Beijing: Cultural Relics Press.

Hubei (Hubeisheng Wenwu KaOgu Yanjiusuo 湖北省文物考古研究所)

1992 Yangxin Dalupu yizhi faqu fajue jianbao 遗址发掘简报. Jianghan Kaogu 3.

2001 Panlongcheng 盘龙城, vols. 1-2. Beijing: Cultural Relics Press.

Itô Michinaru and Takashima Ken-ichi

1996 Studies in Early Chinese Civilization: Religion, Society, language, and Palaeography, vols. 1-2. Osaka: Kansai Gaidai University Publication.

JiANGXI, JiAngXi, AND XIN'GANXIAN (JiAngXisheng WENWU KaOgu YanjIUSUO 江西省文物考古研究

所, JiAngXISHENG Bowuguan 江西省博物館, AND XIN'GANXIAN BOwUGUAN 新平縣博物館)

1997 Xin'gan Shangdai Damu 新干商代大墓. Beijing: Cultural Relics Press.

JiangXi AND Ruichang (Jiangxisheng Wenwu KaOgu Yanjiusuo 江西省文物考古研究所 AND Ruichang Bowuguan 瑞昌博物館)

1997 Tongling gu tongkuang yizhi faxian yu yanjiu 銅領古铜矿遗址发现与研 究. Nanchang: Jiangxi Kexue Jishu Press.

JiangXi AND Tongling (Jiangxisheng Wenwu KaOgu Yanjiusuo 江西省文物考古研究所 AND TONGLING YIZHI FAJUEDUi 銅嶺遗址发掘队)

1990 Jiangxi Ruichang Tongling Shang Zhou kuangye yizhi di yiqi fajue jianbao 江西瑞昌銅領商 周矿冶遗址第一期发掘简报. Jiangxi wenwu 3 .

JiANGXI AND ZHANGSHUSHI (JIANGXISHENG WENWU KAOgU YANJIUSUO 江西省文物考古研究所 AND ZHANGSHUSHI BowUguAN 樟樹市博物館)

2005 Wucheng 1973-2002 nian kaogu fajue baogao 吳城1973-2002年考古發掘報告 [International Conference Papers from Chinese Archaeology Enters the 21st Century]. Beijing: Science Press.

Jin Zhengyao 金正耀

1990 Wan Shang Zhongyuan qingtong de kuangliao laiyuan 晚商中原青铜的矿料来源 [Ore sources for bronze production in the Central Plain during the late Shang period], in Proceedings of the 3rd International Symposium on the History of Science and Technology in China 1984:287291 (杜石然主编，第三届国际中国科学史讨论会北京，1984年8月论文集). Beijing: Science Press.

2000 Erlitou qingtongqi de ziran kexue yanjiu yu Xia wenming tansuo 二里头青铜器的自然科学 研究与夏文明探索, 文物 [Scientific research on the bronzes of the Erlitou culture and exploration of the Xia civilization]. Wen $W u$ 1:56-64, 69.

2002 Scientific and Archaeological Fact: Highly Radiogenic Lead from Southwest China in Early Shang Bronzes. Unpublished lecture presented at Columbia University, November 16, 2002.

2003 Lun xinan diqu zai Shangdai qingtong wenming shi shang de zhongyao diwei (tiyao) 论西南 地区在商代青铜文明史上的重要地位(提要), in Sanxingdui yu chang jiang wenming guoji xueshu yantaohui lunwenji 三星堆与长江文明国际学术研讨会论文集(提要):164 [International Conference Papers from Chinese Archaeology Enters the 21st Century]. Deyang, Sichuan: Sanxingdui yu Changjiang wenming guoji xueshu yantaohui xushuzu.

2008 Zhongguo qiantong weisu kaogu 中国铅同位素考古 [International Conference Papers from Chinese Archaeology Enters the 21st Century]. Hefei: Zhongguo Kexue Jishu Daxue Press.

Jin Zhengyao 金正耀, W. T. Chase, Y. Hirao 平尾良光, Peng Shifan 彭适凡, H. Mabuchi 马渊久 夫, K. Miwa 三轮嘉六, AND Yu KAISUN 誉开逊

1994 Jiangxi Xingan Dayangzhou Shang mu qingtongqi de qiantong weisu bizhi yanjiu 江西新干 大洋洲商墓青铜器的铅同位素比值研究 [A study of the ratios of lead isotopes in bronzes from Shang tombs at Dayangzhou, Xingan]. Kaogu 8:744-747.

Jin Zhengyao, W. T. Chase, 齐思, Y. Hirao 平尾良光, X. Yang 杨锡章, H. Mabuchi 马滟久夫, AND K. Miwa 三轮嘉六

1998 Zhongguo liang heliu huo qingtong wenming zhi jian de lianxi-yi chutu Shang Zhou qingtongqi de qiantong weisu bizhi yanjiu jieguo wei kaocha zhongxin 中国两河流域青铜文明 
之间的联系——以出土商周青铜器的铅同位素比值研究结果为考察中心, [Lead isotope studies: Some preliminary thoughts on the relationship between the bronze civilization in the Yellow RiverValley and the Yangtze RiverValley during the Shang Dynasty], in 中国商文化 国际学术讨论会(河南偃师, 1995年5月)论文集 [Proceedings of the International Symposium on the Shang Culture in Ancient China, Yanshi, Henan Province].

Jin Zhengyao, W. T. Chase, H. Mabuchi 马波久夫, K. Miwa 三轮嘉六, Y. Hirao 平尾良光, D. CHEN 陈德安, AND D. ZhaO 赵殿增

1998c Shangdai qingtongqi zhong de gaofangshe chengyinqian: Sanxingdui qiwu yu Shakele Bowuguan zang pin de bijiao yanjiu 商代青铜器中的高放射成因铅：三星堆器物与沙可乐(赛克 勒)博物馆藏品的比较研究(北京大学, 1993年5月)论文集 [High radiogenic lead in Shang bronzes: A comparative study on the bronze wares from Sanxingdui site and those housed in the Sackler Museum], in 走向二十一世纪的中国考古学国际讨论会 [International Conference Papers from Chinese Archaeology Enters the 21st Century]. Beijing: Science Press.

Jin Zhengyao 金正耀, W. T. Chase, H. Mabuchi 马渊久夫, Peng Shifan 彭适凡, Y. Hirao 平尾良 光, AND YU KAISUN 誉开

1997 Xingan Shangdai Da Mu qingtongqi de qiantong weisu bizhi yanjiu 新干商代大墓青铜器的 铅铜位素比值研究, in Xingan Shangdai damu 新干商代大墓: 245-252. Beijing: Cultural Relics Press.

Jin Zhengyao, E. Childs-Johnson, W. T. Chase, S. Stock, K. R. Ludwig, and R. Mundil

2004 Duolun Duohuangjia Andalue Bowuguan zangzhuan chu Huanbeide Shangdai zaoqi qingtongjia 多伦多皇家安大略博物馆藏传出洹北的商代早期青銅厽 [The Jia Bronze excavated from Huanbei that belongs to the Royal Ontario Museum in Toronto], in Shang Wenming Guoji Taolunhui Lunwen 商文明国际讨论会论文. Beijing: Science Press.

Jin Zhengyao, H. Mabuchi 马洣久夫, W. T. Chase, D. Chen 陈德安, K. Miwa 三轮嘉六, Y. Hirao 平尾良光, AND D. Z HAO

1995 Guanghan Sanxingdui yiqu keng qingtongqi de qiantong weisu bizhi yanjiu 广汉三星堆遗 物坑青铜器的铅同位素比值研究 [A study on lead isotope ratios of the Sanxingdui pit burial bronzes]. Wenwu 2:80-85.

Jin Zhengyao, G. Zheng, Y. Hirao, Y. Hayakawa, and W. T. Chase

1999 Lead isotope study of early Chinese bronze objects, in The Fourth International Conference on the Beginning of the Use of Metals and Alloys (BUMA-IV, ed. B.-I.O. Committee, Matsue, Japan, 1989), Zhongguo Shehui Kexueyuan Renwen Kexue Yanjiu 中国社会科学院人文科学研 究, Beijing: Science Press.

KANE, VIRGINIA

1974 The independent bronze industries in the south of China contemporary with the Shang and Western Chou dynasties. Archives of Asian Art 28 (1974-1975) : 77-107.

1976 A re-examination of An-yang archaeology. Ars Orientalis 10:335-370.

Kaogusuo Institute of Archaeology (Zhongguo Shehui Kexueyuan Kaogu Yanjiusuo 中國社會 科學院考古研究所)

1959 Shangcunling Guoguo Mudi 上村领虢国墓地. Beijing: Science Press.

1965 Henan Yanshi Erlitou yizhi fajue jianbao 河南偃师二里头遗址发掘简报. Kaogu (5):215-224.

1979 1969-1977-nian Yinxu Xiqu mudi fajue baogao 1969-1977年殷噓西区墓地发掘报告. $K a-$ ogue Xuebao $1: 27-146$.

1980 Yinxu Fu Hao Mu 殷噓婦子墓. Beijing: Cultural Relics Press.

1995 Erlitou taoqi jicui 二里頭陶器集粹 [The Cream of Erlitou Ceramics]. Beijing: Science Press.

1998 Anyang Yinxu Guojiazhuang Shangdai Muzang 安陽飲墟郭家庄商代墓葬. Beijing: Zhongguo Daibaike Quanshu Press.

1999 Yanshi Erlitou: 1959 nian-1978 Nian Kaogu Fajue Baogao 偃師二里頭: 1959年-1978年考古 發掘報告. Beijing: Zhongguo Dabaike Quanshu Press.

2005 Tengzhou Qianzhangda Mudi 滕州前掌大墓地. Beijing: Cultural Relics Press.

2008 Zhongguo Zaoqi Qingtong Wenhua 中国早期青铜文化. Beijing: Science Press.

Kaogusuo Anyang Gongzuodui (Zhongguo Shehui Kexueyuan Kaogu Yanjiusuo Anyang GongZUODUI 中國社會科學院考古研究所安阳工作队)

1979 1969-1977 nian Yinxu xiqu muzang fajue baogao 1969-1977年殷噓西区墓葬发掘报告. Kaogu Xuebao 1979 (1): 27-146.

1987 Yinxu 259, 260 hao mu fajue baogao 殷噓259, 260号墓发掘报告. Kaogu Xuebao 1:99-117.

2004 Henan Anyangshi Huayuanzhuang 54 hao Shangdai muzang 河南安陽市花園庄54號商代 墓葬. Kaogu 1:7-9.

Karlbeck, Orvar

1935 Anyang moulds. Bulletin of the Museum of Far Eastern Antiquities 7:39-59. 
Keightley, David

2000 The Ancestral Landscape: Time, Space, and Community in Late Shang China (ca. 1200-1045 B.C.). Berkeley: Institute of East Asian Studies, University of California, and Center for Chinese Studies.

Kern, Martin

2007 The performance of writing in Western Zhou China, in The Poetics of Grammar and Metaphysics of Sound and Sign: 109-176, ed. S. La Porta and D. Schulman. Leiden: Brill.

Ku-Kung (Chung-Yang Ku-Kung Po-wu-yuan Lian-He KuAn-Li-Chu 中央博物院联合管理处)

1958 Ku-kung Tong-chi Tu-lu, vols. 1-2 故宫铜器图录. Taipei: Chung-hua tsung-shu wei-yuan-hui.

KuO-Li Li-ShiH Po-wu-KuAn 国立历史博物馆 AND Henan Bowuguan 河南博物馆

2001 Xinzheng Zhenggong Damu Qingtongqi 新郑郑公大墓青铜器. Taipei: History Museum Press.

Li BoqIAN

1998 Zhongguo Qingtong Wenhua Jiegou Tixi Yanjiu 中国青铜文化结构体系研究. Beijing: Science Press.

Li CHI 李济, ED.

1970 Yin-hsu Ch'u-T'u Ch'ing-t'ung-ch'i Ting-hsing Ch'i Chih Yen-chiu 殷噓出土青铜器鼎形器之 研究. Nangang, Taiwan: Academia Sinica, Institute of History and Philology.

1977 Anyang. Seattle: University of Washington Press.

LI FENG 李丰

2000 Guoguo Mudi Tongqiqun De Fenqi Ji Qi Xiangguan Wenti 虢国墓地铜器群的分期及其相 关问题, in Guoguo mudi de faxian yu yanjiu 虢国墓地发现锋研究: 78-88, ed. Wang Bin 王 斌. Beijing: Science Press.

Li HSIAO-TING 李孝定, ED.

1965 Chia-kuWen-tzu Chi-shi 甲骨文字集釋, 8 volumes. Institute of History and Philology Special Publications: No. 50. Nangang, Taiwan: Academia Sinica, Institute of History and Philology.

Li JiNGHUA 李京华

1999 Fulu Yi: Zhengzhou Shangdai Da Fangding Pinzhu Jishu Shixi 附录一：郑州商代大方鼎拼铸 技术试析, in Zhengzhou Shangdai rongqi jiaozang 鄭州商代銅器藏: 95-111. Henansheng Wenwu Kaogu Yanjiusuo 河南省文物考古研究所 and Zhengzhoushi Wenwu Kaogu Yanjiusuo 鄭州市文物考古研究所. Beijing: Science Press.

Li JINGHUA 李京华 AND GUO YIHONG 郭移洪

1999 Fuluer: Zhengzhou Shangdai rongqi jiaozang 附录二：鄭州商代銅器窝藏: 112-124. Henansheng Wenwu Kaogu Yanjiusuo 河南省文物考古研究所 and Zhengzhoushi Wenwu Kaogu Yanjiusuo 鄭州市文物考古研究所. Beijing: Science Press.

Li XIXING 李西興, ED.

1994 Shaanxi Qingtongqi 陝西青銅器. Xian: Shaanxi Peoples Arts Publishers.

Li XUEQIN 李学勤

1977 Lun “Fu Hao" mu de niandai ji youguan wenti 论妇好墓的年代及有矢问题. Wenwu 11:32-37.

1985 Eastern Zhou and Qin Civilizations. New Haven and London: Yale University Press.

LiU, Li, AND Chen, XingCan

2003 State Formation in Early China. London: Gerald Duckworth \& Co., Ltd.

LIU YUAN 劉源

2004 Shang Zhou Ji Zu Li Yanjiu 商周祭祖禮研究. Beijing: Shangwu Yinshuguan.

Lu BENSHAN 盧本珊

2006 Zhongguo Gudai Kuangye Jishu Yanjiu 中國古代礦冶技術 研究. Hong Kong: Shuji Press.

Lu Benshan 卢本珊 AND Liu Shizhong 刘诗中

1993 Tongling Shang Zhou tongkuang kaicai jishu chubu yanjiu 铜岭商周铜矿开采技术初步研 究. Wenwu 7:33-38.

LuO ZHENYu 罗振玉

1916 Yinxu shu houbian 殷噓书契後编, vols. 1-2. n.p., Taipei reprint, n.d.

Ma Chengyuan 马承源 ED.

1986- Shang Zhou Qingtongqi Mingwen Xuan 商周青铜器铭文选 III. Beijing: Cultural Relics Press. 1988 
Mabuchi, H., and Hirao, Y.

1987 Lead isotope ratios of lead ore deposits in East Asia. Archaeology 73 (2):71-117.

Needham, Joseph, Ho Ping-yu, and Lu Gwei-Djen

1976 Science and Civilization in China: Alchemy and Chemistry, vol. 5, part 3. Cambridge: Cambridge University Press.

Nivison, DAVID

1999 Key to the Chronology of the Three Dynasties: The "Modern Text" Bamboo Annals. Philadelphia: Department of Asian and Middle Eastern Studies, University of Pennsylvania.

2009 The Riddle of the Bamboo Annals (Chu Shu Chi Nien Jie Mi 竹書紀年解謎). Taipei: Airiti Press.

PANKenier, DAVID W.

1981- Astronomical dates in Shang and Western Zhou. Early China 7:2-37.

1982

1995 The cosmo-political background of Heaven's Mandate. Early China 20:121-176.

Peng BANGJIONG 彭邦畑

1988 Shangshi Tanzheng 商史探徵. Beijing: Xinhua Shudian.

Peng Minghan 彭明瀚

2010 Shangdai Jiangnan 商代江南. Beijing: Science Press.

Peng Shifan 彭适凡

1985 Jiangxi zaoqi tongqi zhizhu jishu de jige wenti 江西早期铜器铸技术的几个问题, in 第四 届中国考古學術年会論文集 (Proceedings of the 4th Chinese Archaeology Annual Symposium). Beijing: Cultural Relics Press.

1997 You guan Xingan Shangdai damu de liangge wenti 有䏌新干大墓的两个问题, in $W u$ Yue Diqu qingtongqi yanjiu lunwenji 吴越地区青铜器研究论文集. Hong Kong: The Woods Pub. Co.

Peng Zicheng, Zhang Zhaofeng, He Jianfeng, Wang Zhaorong, Liu Shizhong, and Hua Jueming 2000 Lead isotopic study of Shang Dynasty bronzes (13th-11th c. BC) and their ore sources. Nuclear Science and Techniques 11(2):

Pope, John Alexander

1967 The Freer Chinese Bronzes: I Catalogue and II Technical Studies. Washington, D.C.: Smithsonian Institution Freer Gallery of Art.

Pope, John A., James Cahill, and Rutherford John Gettens

1967 The Freer Chinese Bronzes Volumes I, Catalogue. Washington, D.C.: Smithsonian Institution, Freer Gallery of Art, Oriental Studies, No. 7.

QIAN

1913 Yinxu Shuqi Qianbian 殷噓書契前編, compiled by Luo Zhenyu 羅振玉. Taipei: Yiwen.

QiU Xigui

1985 Jiagu Buci Zhong Suojian De Nisi 甲骨卜辞中所见的逆祀. Beijing: Wenwu Chubanshe.

RawSON, JESSICA

1990 Western Zhou Ritual Bronzes from the Arthur M. Sackler Collections, 2 vols. Washington, D.C.: Arthur M. Sackler Foundation.

1994 Contact between Southern China and Henan during the Shang period. Transactions of the Oriental Ceramic Society, London $57: 1-14$.

SHAANXI WENWU KAOGUSUO 陕西省文物考古研究所

1976 He zun 何尊, Wenwu 1:60-66.

Shanxi Sheng Kaogu Yanjiusuo 山西省考古研究所, Taiyuanshi Wenwu Guanli Weiyuanhui 太原 市文物管理委员会, TAO ZHENGGANG 太原市文物管理委员会, Hou Y I 太原市文物管理委员会, AND QU CHUANFU 渠川福

1996 Taiyuan Jinguo Zhaoqingmu 太原晋国赵卿墓. Beijing: Cultural Relics Press.

Shima Kunio 岛邦南

[1958] Yinxu BuciYanjiu (Yin-hsu Pu-t'zuYen-chiu) 殷噓卜辞研究, trans. Wen Tian-he 文天河 and Li

1975 Shou-lin 李寿林. Taipei: Ting-wen Ch'u-pan-she.

1967 Inkyo Bokuji Sôrui 殷噓卜辞综类. Tokyo: Kyûko.

SHIRAKawa SHIzUKa 白川静

1977 Chia-ku-wen Te Shih-chieh-Ku Yin-wang-chao Te Ti-kou 甲骨文的世界一一古代殷王朝的缔构, translated from Kôkotsubun No Sekai-Kodai In Ochô No kôzô 甲骨文の世界—古代殷王朝 の构造, trans. Cai Zhemao 蔡哲茂 and Wen Tianhe 溫天河. Taipei: Chu-liu tu-shu kung-tse. 
Sichuan (Sichuansheng Wenwu Kaogu Yanjiusuo 四川省文物考古研究所)

1999 Sanxingdui Jisi Keng 三星隊祭祀坑. Beijing: Cultural Relics Press.

SMith, AdAM

2008 Writing at Anyang: The Role of the Divination Record in the Emergence of Chinese Literacy. Los Angeles: University of California Press.

SONG XINCHAO 宋新潮

1991 Yin Shang wenhua chuyu yanjiu 殷商文化区域研究. Xian: Shaanxi Peoples Press.

SONG ZHENHAO 宋镇毫

2005 Xia Shang Shehui Shenghua Shi 夏商社会生话史, 2 vols. Beijing: Science Press.

SONG ZHENHAO 宋镇毫 AND LiU YUAN 劉源

2006 Jiaguxue Yin Shang Shi Yanjiu 甲骨學殷商史研究. Fujian Peoples Press.

SOPER, Alexander C.

1966 Early, Middle and Late Shang: A note. Artibus Asiae 28 (1) :5-38.

TANG JigEN 唐际根

1999 Zhongguo wenhua yanjiu 中国文化研. Kaogu Xuebao 4:393-420.

TONG ENZHENG 童恩正

1983 Notes on relations between ancient cultures in Sichuan and Southeast Asia 四川古代文化与 亚洲东南古代文化的矢系笔记. Wenwu 9:73-81.

Tung TSO-PIN 董作宾

1945 Yin Lipu 殷礼谱. Lichuang: Institute of History and Philology, Academia Sinica.

1964 Sixty Years in Oracle Studies. Tokyo: Centre for East Asian Cultural Studies.

UNDERHILL, ANNE

2002 Craft Production and Social Change in Northern China. Kluwer Academic/Plenum Publishers.

WANG YUXIN 王宇信

1979 Shilun Yinxu Wuhaomu De Niandai 试论殷噓五好号墓的年代. Zhengzhou Daxue Xuebao 2.

1984 Xi Zhou Jiagu Tanlun. 西周甲骨談論. Beijing: Zhongguo Shehui Kexue Chubanshe.

WANG YuXin 王宇信, Zhang YongShan 張永山, AND YANG SHENGNAN 楊升南

1977 Shilun Yinxu wuhao mu de “Fu Hao”試論飲噓五號墓的“婦好” Kaogu Xuebao 2:1-22.

WEI SI 衛斯

1992 Pingluxian Qianzhuang Shangdai yizhi chutu wenwu 平陸縣前庄商代遺址出土文物. Wenwu Jikan 文物季刊 $1: 18-19$.

Wheatley, Paul

1971 Pivot of the Four Quarters: A Preliminary Enquiry into the Origins and Character of the Ancient Chinese. Edinburgh: Edinburgh University Press.

Wu Hung

1989 The Wu Liang Shrine, The Ideology of Early Chinese Pictorial Art. Stanford: Stanford University Press.

1995 Monumentality in Early Chinese Art and Architecture. Stanford: Stanford University Press.

Xia Shang Zhou Duandai (XIA Zhang Zhou DuAndai gOngCheng Zhuanjiazu 夏商周断代工程专 家组夏商周断代功成 [XIA, Zhang, Zhou Chronology Study Group])

2000 Xia Zhang Zhou Duandai Gongcheng 1996-2000-Nian Jieduan Chengguo Baogao Jianben 夏商周 断代工程1996-2000年阶段成果报告·简本. Beijing: Shijie Tushu Chuban Gongsi.

YANG BAOCHENG 楊寶成

2002 Yinxu Wenhua Yanjiu 殷噓文化研究. Wuhan: Wuhan University Press.

YANG BAOCHENG 楊寶成 AND LIU SENMIAO 劉森永

1991 Shang Zhou Fangding Chulun 商周方鼎初論. Kaogu 6:533-545.

YANG CHIA-KO 杨家骆

1976 Shi-chiYin-pen-chi Shu-cheng 史记殷本纪疏证. Taipei: Ting-wen Shu-zhu.

YANG LIXIN 杨利新

1998 Tongling gudai tongye shelu 铜陵古代铜业铜爐. Wenwu Yanjiu 文物研究 11:238-245.

YANG SHENGNAN 扬升南

1992 Shangdai jingji shi 商代经济史. Guizhou: Guizhou Peoples Press.

2004 Yinxu Hua Dong H3 buci “Zi” de zhuren shi Wu Ding taizi Xiao Ji H3殷噓花东H3卜辞 “子” 的主人是武丁太子孝己, in 2004-nian Anyang Yin Shang Wenming guoji xueshu yantaohui lunwenji 2004-年安阳因上文明国际学术研讨会论文集 : 204-210, ed. Wang Yuxin, Song Zhenhao, and Mengxianwu. Beijing: Shehui Kexue Wenxian Press. 
YANG XIZHANG 杨锡璋

1981 Anyang Yinxu Xibeigang damu de fenqi ji you guan wenti 安阳殷噓西北冈大墓的分期及 有矢问题. Zhongyuan Wenwu 中原文物3.

1983 Yindai mudi zhidu 殷代墓地制度. Kaogu 考古10.

YAO XIAOSUI 姚孝遂 AND XIAO DING 当丁

1989 Yinxu Jiagu Kece Leizuan 殷噓甲骨刻辞类纂. Beijing: Zhonghua Shuju Yingyin.

Ye WeNXIAN 叶文宪

1990 Shangdai jiangyu xinlun 商代疆域新. Lishi Dili 历史地理8.

Young, M. L., F. Casadio, J. Marvin, W. T. Chase, and D. C. Dunand

2010 An ancient Chinese bronze fragment re-examined after 50 Years: Contributions from modern and traditional techniques. Archaeometry 52 (6):1015-1043.

YU WEICHAO 俞伟超

1995 Zhoudai yongding zhidu yanjiu 周代用鼎制度, in Xianqin Lianghan Kaoguxue Lunji: 62-114. Beijing: Cultural Relics Press.

Yu WeIchaO 俞伟超 AND GaO Ming 高明

1978- Zhou dai yongding zhidu yanjiu 周代用鼎制度研究. Beijing Daxue Xuebao 北京大学学报

19791978 (1):84-98; 1978 (2):84-97; and 1979 (1):83-96.

ZHANG Xuelian 張雪蓮, Qiu ShiHua 仇士華, AND CAi LianZhen 蔡蓮珍

2005 Zhengzhou Shangcheng he Yanshi Shangcheng de tanshise niandai fenxi 鄭州商城和偃師商 城的碳十四年代分析. Zhongyuan Wenwu 1:34-41.

ZHANG YACHU 張亞初

1985 Dui Fu Hao zhi hao yu chengwei zhi si de pouxi 對婦好之好与稱謂之司的剖析. Kaogu $12: 1119-1123$.

Zhongguo (Zhongguo Qingtong Quanji Bianji Weirhuanhui 中國青銅全集編輯委員會)

1997 Zhongguo Qingtong Quanji, vol. 1: Xia Shang 中國青銅全集 1夏商; vols. 2-4: Shang 2-4 商. Beijing: Cultural Relics Press.

ZhongGuO Meishu

1996 Zhongguo Meishu Quanji 中國美術全集. Beijing: Cultural Relics Press.

ZHU BINGQUAN 朱炳泉 AND CHANG XIANGYANG 常向阳

2002 Ping “Shangdai qingtongqi gaofangshexing chengyinqian” de faxian 评“商代青铜器高放射 性成因铅”的发现 [Discussion of the discovery of lead produced with high radioactivity]. Gudai Wenming 1:278-283.

ZHu FeNGHAN 朱风瀚

1986 Lun Buci yu Shang Zhou Jinwen zhong de “Hou”论卜辞与商周金文中的 “后”. Zhongguo Wenzi $13: 423-443$.

1990 Shang Zhou Jiazu Xingtai Yanjiu 商周家族形态研究. Tianjin Guji Press.

Zou HeNG 㮲衡

1980 Xia Shang Zhou Kaogu Xue Lunwen Ji 夏商周考古學論文集. Beijing: Cultural Relics Press.

\begin{abstract}
Paleographic, art historical, metallurgical, and archaeological data are used to identify the monumental bronze tetrapod ding vessel as a preeminent symbol of state authority and divine power during the Shang era of ca. 1640-1046 в.C.E. Paleographic data based on oracle bone terms and inscriptions includes reference to ding as a verb of ancestral sacrifice, and the ding vessel in the specialized compound, yiding, referring to the ritually and metamorphically empowered ding vessel. Art historical data accounts for differences in form and style between ding tetrapod and tripod types. Metallurgical data derives primarily from a unique source of high radiogenic lead in southern China exploited during the early Shang period. Archaeological data derives from excavated Shang tetrapod ding in royal burial or cache burials. KEYwords: China, Shang, history, writing, bronze, kings, divine power, oracle bone divination, ritual vessels, ancestor worship, ancestral sacrifices, legend.
\end{abstract}

